\author{
Universidade de São Paulo \\ Instituto de Psicologia
}

Mauricio Mathias Rodrigues

\title{
Não é assim que a banda toca: Uma análise das deliberações judiciais acerca da adolescência em conflito com a lei
}

São Paulo 


\title{
Universidade de São Paulo \\ Instituto de Psicologia
}

Mauricio Mathias Rodrigues

Versão Corrigida

\section{Não é assim que a banda toca: Uma análise das deliberações judiciais acerca da adolescência em conflito com a lei}

\author{
Tese apresentada ao Instituto de Psicologia da \\ Universidade de São Paulo como requisito parcial \\ para obtenção do título de Doutor em Psicologia \\ Social \\ Área de Concentração: Psicologia Social \\ Orientador: Gustavo Martineli Massola
}

São Paulo 
Rodrigues, Mauricio Mathias. Não é assim que a banda toca: Uma análise de deliberações judiciais acerca da adolescência em conflito com a Lei. 2018. 151 paginas. Tese (Doutorado) Instituto de Psicologia, Universidade de São Paulo, São Paulo, 2018.

Aprovado em:

\section{Banca Examinadora}

Prof. Dr.

Instituição:

Julgamento:

Prof. Dr.

Instituição:

Julgamento:

Prof. Dr.

Instituição:

Julgamento:

Prof. Dr.

Instituição:

Julgamento:

Prof. Dr.

Instituição:

Julgamento: 


\section{Agradecimentos}

Nas próximas linhas pretendo cumprir uma tarefa fundamental num trabalho como este, o reconhecimento. Agradeço ao Conselho Nacional de Desenvolvimento Científico pelo auxílio e fomento no decorrer desta pesquisa. Para minha Rosemarie, a explosão de sentimentos em forma de mulher que faz cada dia da minha vida querer amanhecer em poesia. Dedico também meus mais sinceros agradecimentos a meu orientador Gustavo Massola, por acreditar desde o princípio, instigar o pensamento desde sempre e por tudo que compartilhamos nestes quatro anos, , por pcom o sorriso mais de bom moço desse mundo. A minha família por me iniciar no caminho das letras e das descobertas. A meus amigos de longe mas sempre perto dos Mal ditos, Rato, Ogrão, Rafa, Carlos, Alessandra e Átila, que a música continue a nos aproximar. Aos meus colegas de percurso na ponta: Sidão, Cleverson, Danielle, Débora, Patrícia, e Lilian, o aprendizado desta equipe é só mais uma das muitas boas lembranças. Agradeço a Vera por apresentar a arte do encodest a cada manhã. A professora Maria do Carmo por todo o conhecimento partilhado e pela paixão da pesquisa. Ao professor Paulo Malvasi, pelo espaço de acolhida e escuta e a produção que sempre me inspirou e finalmente ao Emanuel, que chegou no meio do caminho mas já é de longe meu melhor para o mundo.

Rodrigues, Mauricio Mathias. Não é assim que a banda toca: Uma análise de deliberações judiciais acerca da adolescência em conflito com a Lei. 2018. 151 paginas. Tese (Doutorado) Instituto de Psicologia, Universidade de São Paulo, São Paulo, 2018. 
No campo de estudos dos sistemas jurídicos da Infância e da adolescência, a Lei 8.069 de 13 de julho de 1990 a qual instituiu o Estatuto da criança e do Adolescente - ECA representa um importante marco legal na relação entre adolescência e criminalidade, rompendo com a perspectiva de legislações anteriores instaurando o Paradigma da Proteção Integral nas ações de responsabilização diante de condutas infracionais (Brasil, 1990). Todavia, esta transformação condicionava uma mudança estrutural no Sistema de Justiça Juvenil, que houveram se constituído sob a égide das normativas anteriores. Trata-se de estudo exploratório de processos socioeducativos aplicados a adolescentes que cometeram ato infracional na cidade de São Paulo entre os anos de 2015 e 2016. A questão das drogas e do tráfico funciona, ao mesmo tempo, como eixo aglutinador dos delitos estudados na presente tese como também contextualiza o campo macrossocial de vulnerabilidades e violações que atingem entre outras populações crianças e adolescentes residentes nas periferias das grandes cidades. Ao curso do presente estudo buscamos publicizar reflexos desta justaposição de paradigmas na justiça juvenil, discorrer sobre os hibridismo e as posições que coabitam os pólos das Doutrinas da Situação Irregular e da Proteção Integral (Gomes, 2012), a partir do olhar da Psicologia Social, das ferramentas metodológicas de análise documental e de conteúdo e do diálogo teórico com os postulados de Michel Foucault e Loic Wacquant, naquilo em que tratam da vontade de verdade nas práticas jurídicas e da criminalização da pobreza nas sociedades contemporâneas. Não obstante os avanços recentes, as políticas públicas para a infância e adolescência ainda possuem caráter Penal-Policial institucionalizado nas práticas do Estado. O desafio de efetivar e garantir a Proteção Integral, tal qual sugere a Doutrina ainda permanece.

Palavras-chaves; Psicologia Social; Juventude; Justiça; Tráfico de drogas;

Rodrigues, Mauricio Mathias. Things don't work that way: An analysis of judicial deliberations about the adolescence in conflict with the Law. 2018. 151 pages. Doctoral thesis - Instituto de Psicologia, Universidade de São Paulo, São Paulo, 2018. 
ABSTRACT

For the studies of legal systems concerning Childhood and Adolescence, Law no. 8.069 of July $13^{\text {th }}$, 1990, which set for the Statute of the Child and Teenager (ECA), represents an important legal milestone concerning the relation between adolescence and criminality, breaking the perspective of previous laws and establishing the Full Protection Paradigm in actions for damages due to offenses (Brasil, 1990). However, this transformation required a structural change in Juvenile Justice System, which has been built under the auspices of previous rules. This is an exploratory study of social and educational processes applied to teenagers who committed any offense in the city of São Paulo between 2015 and 2016. The drug and trafficking issues at the same time work as a unifying axis of the offenses herein studied and sets the macrosocial field of vulnerabilities and violations affecting, in addition to other populations, children and teenagers living in the outskirts of major cities. Throughout this study, we aimed at publicizing the reflexes of this juxtaposition of paradigms in juvenile justice, discussing the hybridity and the positions sharing the poles of both the Irregular Welfare and the Full Protection Doctrines (Gomes, 2012), from the perspective of the Social Psychology, the methodological tools for document and content analysis and the theoretical dialogue with Michel Foucault's and Loic Wacquant's theories, concerning the true will in legal practices and the criminalization of poverty in contemporary societies. Notwithstanding recent advances, public policies for childhood and adolescence still have criminal aspects institutionalized in the practices of the State. The challenge of making the Full Protection effective and ensuring it as suggested by the Doctrine is still on.

Keywords: Social Psychology; Youth; Justice; Drug trafficking; 


\section{Sumário}

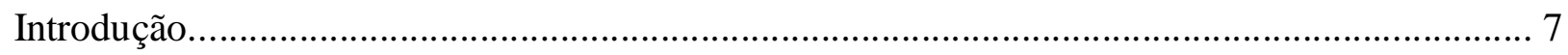

Apresentação dos movimentos de pesquisa................................................................................ 9

\section{Capítulo 1.}

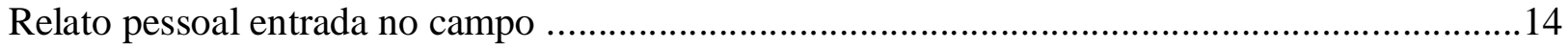

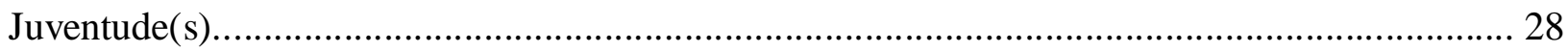

A questão das drogas e a Socioeducação.........................................................................................33

\section{Capítulo 2.}

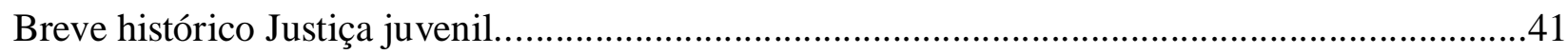

A Lei 12.594 - SINASE e o Departamento de Execuções da Infância e Juventude de São Paulo

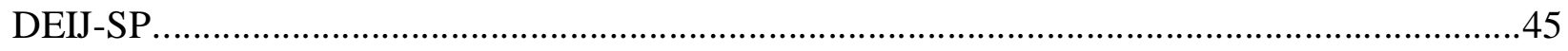

\section{Capítulo 3}

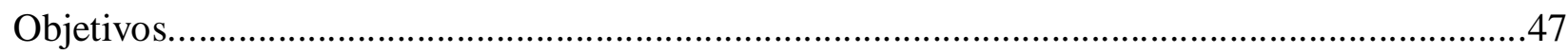

Apontamentos metodológicos.................................................................................................48

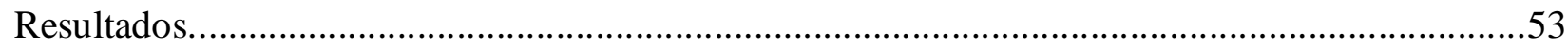

Como a banda toca: Análise e discussão....................................................................................56

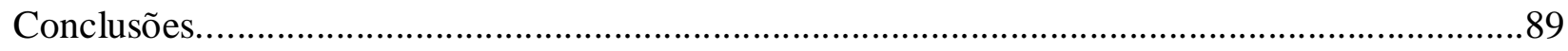

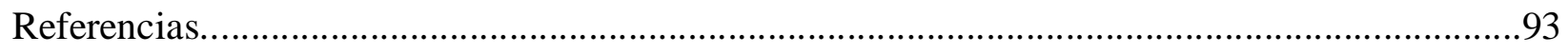

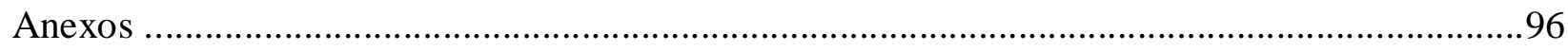




\section{Introdução}

Em 18 de abril de 2012 entram em vigor, em todo o território nacional, as diretrizes da Lei Federal 12.594, que institui o Sistema Nacional de Atendimento Socioeducativo - SINASE, este por sua vez, originado da Resolução N ${ }^{0} 119$, do Conselho Nacional dos Direitos da Criança e do Adolescente - CONANDA editada no ano de 2006. Fruto de ampla discussão e elaboração das instituições envolvidas, o texto legal sancionado noventa dias antes pela presidenta Dilma Roussef houvera tramitado quatro anos no Congresso Federal e surge, com o propósito de preencher a lacuna referente aos procedimentos de execução das medidas socioeducativas aplicáveis a adolescentes que apresentem condutas equiparadas a crimes ou tipificadas de acordo com o Código Penal. O SINASE vem complementar os dipositivos legais previstos pela Lei Federal 8.069 de 1990, que dispõe sobre o Estatuto da Criança e do Adolescente - ECA, (Araujo, Neto \& Albino, 2012), em especial no Título III que trata da prática de atos infracionais.

Ao passo da redação destes parágrafos, a qual esboça uma breve retomada da legislação recente sobre direitos da infância e adolescência no país, uma importante decisão deverá ser tomada nas próximas semanas na capital brasileira. Desde sempre nas pautas do Congresso Nacional, ao menos desde 1988, as Propostas de Emendas Constitucionais - PEC que miram alterar a redação do artigo 228 da Constituição Federal: “Art. 228 - São penalmente inimputáveis os menores de dezoitos anos, sujeitos às normas da legislação especial” devem ganhar um novo capítulo no corrente ano (Furlan \& Mastellini, 2016). A PEC que será discutida em 2018, deriva de projetos iniciados em 2011 e 2015 (Folha de São Paulo, 2017), fora retomada em 2017 e adiada para o corrente ano, uma vez que se trata de matéria polêmica e a política brasileira sempre recomenda que estas matérias sejam votadas com cuidado na proximidade de anos eleitorais.

Em suas últimas tramitações em 2017, a perspectiva entre os governistas, parlamentares alinhados à representação política do Executivo, é que se debrucem sobre substitutivos ao Projeto inicial, tal como propõe o Senador Romero Jucá do PMDB em entrevista ao Jornal Folha de São 
Paulo: “Qualquer radicalismo de proposta não é bom para a Sociedade. (...) tem que discutir, Hoje há um abuso que tem que ser controlado.” (Entrevista à Folha de São Paulo, 2017). Dentre as muitas propostas correlatas de alteração ao Artigo constitucional supra citado, sugestão comum a quase todas elas se refere à redução da faixa etária, considerada inimputável para a Justiça criminal, passando dos atuais dezoito para dezesseis anos. A PEC 33/2012, atualmente em tramitação no Senado Federal brasileiro, além da redução etária também sugere outra modificação importante. Para aqueles com idade entre 16 e 18 anos, as quais tenham cometido algum tipo de infração ou ilícito penal considerados graves ou hediondos, tais como homicídios, tráfico de drogas, latrocínio, lesão corporal, roubo qualificado, tortura e terrorismo, a decisão sobre a equiparação no processo de responsabilização legal seja decidido individualmente, caso a caso pelos magistrados que julgam as referidas condutas .

A PEC 33/2012 representa, também por seu apoio governista, esta posição menos radical no debate sobre a redução, uma vez que condiciona a mudança legislativa apenas para casos excepcionais, aos quais evocam o clamor popular na questão. Todavia, uma parcela significativa da produção acadêmica sobre o tema vem, recorrentemente, alertando sobre resquícios de uma lógica de criminalização da pobreza nestes substitutivos recentes (Silva, 2010). Uma redação legal que se apresenta precisa e imparcial, atenta aos anseios da população mas que revela muito de seu caráter em suas brechas. A discricionariedade dos Juízes na Seara da Infância e Adolescência já completa um século nas descrições da literatura e o conceito de crimes graves também não é uma das verdades mais sólidas da legislação brasileira, que o digam os muitos pesquisadores que investigam as questões ligadas à política de drogas e ao proibicionismo, modelo de atuação padronizada internacional entre algumas nações diante determinadas substâncias entorpecentes ou psicoativas (Torcato, 2014; Fiore, 2017; Rocha, 2012). 


\section{Apresentação dos movimentos de pesquisa}

No campo de estudos dos sistemas jurídicos voltados à Infância e à adolescência, o Estatuto da Criança e do Adolescente ECA representa um importante marco legal na relação entre adolescência e criminalidade rompendo com a perspectiva de legislações anteriores, instaurando, no âmbito da Justiça Juvenil o Paradigma da Proteção Integral nas ações de responsabilização diante de condutas infracionais, postulando diferentes níveis de resposta em conformidade com a faixa etária do autor: para aqueles com até 12 anos, medidas protetivas, e para aqueles com idade entre 12 e 18 anos, as mesmas medidas protetivas acrescidas das referidas medidas socioeducativas (Brasil, 1990).

Ao considerar crianças e adolescentes como responsáveis pelos atos ilícitos que praticam, sem que para esta sanção seja desconsiderada a situação peculiar de pessoas em desenvolvimento, o Estatuto da Criança e do Adolescente - ECA, introduz um componente central para a plena cidadania deste público, o reconhecimento na letra da Lei de sua condição de sujeitos de direitos.

Como um desdobramento da teoria jurídica do contrato social, a noção de responsabilidade penal parte do pressuposto da capacidade de optar livremente e também da consciência do ônus decorrente de sua ação, da qual resultará uma pena prevista para uma conduta tipificada (Carvalho \& Weigert, 2010). Ainda que, como veremos adiante, critérios etários de inimputabilidade já existissem em legislações anteriores á Constituição Federal de 1988, fora somente em nossa última Carta Magna que se consagrou a sanção socioeducativa como resposta para delitos praticados por aqueles com idade inferior a 18 anos de idade.

Destaca-se nesta nova propositura, ao lado do viés garantista, o caráter educativo nas respostas aos conflitos que é o objetivo maior no novo ordenamento, no qual os legisladores privilegiaram o caráter pedagógico em detrimento à visão de defesa social, elegendo a educação como principal instrumento para enfrentamento da criminalidade potencial. (Vicentin, 2006; Paula, 2006; Costa, 2015). 
Todavia, a mudança paradigmática na legislação condicionava uma mudança estrutural nas formas de atenção à relação juventude e práticas ilícitas, uma vez que, os equipamentos do Poder Público, historicamente responsáveis por estas questões, houveram se constituído sob a égide das normativas anteriores, as quais reservavam a este público práticas institucionais que perpassavam pela segregação ou pela irregularidade da situação em que a lei inscrevia estes adolescentes.

Ao curso do presente estudo buscamos publicizar reflexos desta justaposição de paradigmas na justiça juvenil, discorrer sobre os hibridismo e as posições que coabitam os pólos das Doutrinas da Situação Irregular e da Proteção Integral (Gomes, 2012), a partir do olhar da Psicologia Social, das ferramentas metodológicas de análise documental e de conteúdo e do diálogo teórico com os postulados de Michel Foucault e Loic Wacquant, naquilo em que tratam da vontade de verdade nas práticas jurídicas e da criminalização da pobreza nas sociedades contemporâneas (Wacquant, 2001; 2004; Foucault, 2002, 2001,1984).

A coexistência de perspectivas diversas sobre responsabilização na justiça Juvenil nos tribunais da Infância e Juventude de nosso país, tem sido uma temática recorrente na produção cientifica sobre a questão, em especial nas últimas décadas. Muitos pesquisadores apontam, a partir da análise dos discursos de operadores jurídicos-sociais, a reedição de velhos constructos menoristas, (como ficaram conhecidas na literatura as legislações anteriores ao Paradigma da proteção Integral) nas atuais práticas forenses junto à infância, resultando em processos de culpabilização do indivíduo em detrimento de uma atuação articulada da Justiça Juvenil com as demais políticas públicas tal qual propõe o Estatuto da Criança e do Adolescente. (Jimenez \& Frasseto, 2015; Costa, Penso, Sudbrack \& Jacobina, 2011; Sartório \& Rosa, 2010).

Esta percepção de um campo de interstícios na Justiça Juvenil também surgiu, para o autor desta tese, a partir do exercício profissional como Técnico em Medidas Socioeducativas, função que fora desempenhada durante dois anos em serviços conveniados com a Secretaria Municipal de Assistência e Desenvolvimento Social da cidade de São Paulo SMADS-SP. Fora exatamente em muitas destas situações da ponta da política pública, do cotidiano do trabalho 
socioeducativo com os adolescentes que muitas das questões que desembocaram na necessidade de articulação teórica neste tema tiveram sua origem.

A hipótese de um gradiente de posições e atuações nas Varas da Infância e Juventude apontava um conflito com o absoluto da verdade que o Juiz representava. Uma verdade que se afirma por uma vontade, a qual define também as vidas daqueles sob seu crivo, neste caso adolescentes e jovens negros e moradores das periferias, ou ainda nas palavras de Foucault:

As práticas judiciárias - a maneira pela qual, entre os homens se arbitra os danos e as responsabilidades, o modo pelo qual, na história do Ocidente, se concebeu e se definiu a maneira como os homens podem ser julgados em função dos erros cometidos (... ) me parecem uma das formas pelas quais nossa sociedade definiu tipos de subjetividade, formas de saber e, por conseguinte, relações entre o homem e a verdade que merecem ser estudadas” (2001, p.11)

Assim, para caminhar "entre formas de verdade que produzem exclusão" no cotidiano dos ritos processuais (Scisleski \& Guareschi, 2011) propusemos movimentos que investigassem narrativas: narrativas que se alinhassem com o constructo constitucional da garantia de direitos, outras que revelassem sua preferencia pela Doutrina menorista como também, aquelas que estão no meio do caminho entre essas posições. Nossa pergunta de pesquisa então considera as possibilidades de reedição de categorias ou fenomenos já descritos na literatura em outros períodos ou em outros contextos, acrescido da perspectiva de uma investigação que se concebe sob a égide de uma nova legislação, a Lei 12.594 de 2012 - SINASE. Acreditamos que neste recorte situa muitos dos embates e desafios do campo com a particularidade da experiência pessoal do autor do pesente estudo. (Miranda et al. 2014; Gomes, 2012; Maraschin \& Raniere, 2011; Miraglia, 2005).

Elegemos como campo de pesquisa para esta incursão as audiências judiciais de apresentação, a qual integram a garantia ao devido processo legal quando constatado a ocorrência de ato infracional, tal como definido nos Artigos 110, 103 e 104 da Lei 8.069 de 1990. O registro integral das seções, realizado pelo escrevente judiciário nas situações de audiência, representa a materialização do trabalho jurídico e estabelece com este uma relação de composição mútua que 
é da natureza do exercício da Lei. Sua legitimidade está necessariamente atrelada a seu reflexo físico no papel, no ofício, na intimação. Compartilhamos da percepção de que neste território, delimitado por ritos e estruturas aparentemente estanques, a qual cotidianamente, histórias de vida e seus conflitos aguardam a porta se abrir para o início dos trabalhos, práticas e saberes da vida em Sociedade podem ser redesenhados a cada sessão e outras formas de exercício da subjetividade podem surgir ao fim do dia. (Miraglia, 2005; Pastore, 2007).

Para tal intento dividimos este trabalho em três capítulos que visam construir um contexto argumentativo que, além da apresentação do caminho de pesquisa e seu desenvolvimento possibilite a construção conjunta com o leitor do terreno sob a qual se assenta as questões que propomos. Sendo assim no Capítulo de número 1 os temas foram abordados em três subcapítulos. No primeiro deles, que se intitula: Relato Pessoal de Entrada no Campo, buscamos reconstruir a intersecção que se estabelece entre a história pessoal deste que subscreve e a história dos fenômenos presentes na Socioeducação e na Justiça Juvenil. No segundo subcapítulo, intitulado Juventude(s), discorremos sobre alguns dos conceitos de Juventude que têm se discutido nas Ciências Humanas, bem como sobre críticas a estas definições. Almejamos com este subcapítulo sedimentar o terreno teórico-discursivo na qual se inserem nossos protagonistas. No último subcapítulo deste tomo intitulado A Questão das Drogas e a Socioeducação, inserimos um marcador importantíssimo para nossa problematização. Sob a perspectiva adotada no estudo, o tráfico de drogas funciona, ao mesmo tempo, como eixo aglutinador dos delitos estudados na presente tese, como também estabelece o contexto macrossocial de vulnerabilidades e violações que atingem entre outras populações crianças e adolescentes. Seguindo a linha de muitos pesquisadores que já há muito tempo se aprofundam nessas discussões, procuramos demonstrar no presente texto o poder que a tríade Tráfico, criminalidade e juventude tem de revelar e trazer à tona, nas práticas da Justiça Juvenil, a gama de variações possíveis entre a Doutrina da Situação Irregular e a Doutrina da Proteção Integral.

No segundo capítulo, desenvolvemos um percurso histórico a partir da produção bibliográfica e historiográfica sobre a questão juventude e criminalidade. No primeiro subcapítulo desta seção intitulado Breve Histórico da Justiça Juvenil apresentamos uma cronologia que se debruça desde alguns dos primeiros registros de práticas infracionais cometidas 
por crianças e adolescentes nos documentos oficiais brasileiros chegando até as mais recentes normativas Legais sobre a questão. No subcapítulo seguinte intitulado A Lei 12.594 - SINASE e o Departamento de Execuções da Infância e Juventude de São Paulo DEIJ-SP abordamos um recorte da construção da referida normativa considerando seu papel fundamental na continuidade da missão da lei 8.069, a saber, resgatar e assegurar direitos para a Infancia e Adolescencia nesta perspectiva intentamos revelar a múltipla composição de atores na luta pela consolidação do referido arcabouço teórico, a qual envolveu trabalhadores da área da infância e adolescência, comunidades eclesiais de base e membros do poder Judiciário, representando uma conquista constitucional que desafia a lógica de uma Justiça apenas a serviço das penas.

No terceiro e último capítulo desta tese apresentamos os desenvolvimentos e reflexões realizadas a partir dos dados colhidos em campo. Para tal intento subdividimos novamente em três subcapítulos que serão apresentados a seguir. No primeiro subcapítulo, intitulado Apontamentos Metodológicos, aprofundamos o detalhamento de nossas ferramentas de pesquisa, a partir das definições de recorte e ferramentas de tratamento de dados. Neste sentido, neste subcapítulo será possível acompanhar desdobramentos do ingresso no campo de pesquisa, adaptações e peculiaridades do contexto, a saber a dinâmica de funcionamento do Departamento de Execuções e as etapas de seleção e filtragem do material, que resultou em 9 processos para análise de um universo de 72 processos consultados no período de abril a dezembro de 2016. Nesta seção também discorreremos sobre a ferramenta de tratamento de dados escolhida para nosso estudo, a saber, a Análise de Conteúdo sob a perspectivas das autoras Minayo e Bardin.

No subcapítulo seguinte apresentamos as discussões e os resultados das etapas de tratamento de tratamento de dados, apresentando no referido texto os critérios para seleção de frequências a partir dos conteúdos indicados nas seções anteriores, bem como as categorias temáticas geradas destas etapas. Por fim, no último subcapítulo apresentamos as conclusões finais da tese, a refutação ou confirmação da hipóteses iniciais bem como as novas perguntas geradas e deixadas para continuidade. 


\section{Capítulo 1}

\section{Relato pessoal da entrada no Campo}

O constructo constitucional da condição peculiar de pessoa em desenvolvimento que legitima a garantia do pleno exercício de direitos para crianças e adolescentes surgiu há quase três décadas, com a Lei federal 8.069 de 1990 - regulamentando em todo o país as disposições do Estatuto da Criança e do Adolescente. Destaca-se o caráter educativo das sanções previstas pelo novo ordenamento, no qual os legisladores privilegiaram o caráter pedagógico em detrimento à visão de defesa social, elegendo a educação como principal instrumento para enfrentamento da criminalidade potencial. (Paula, 2006; Costa, 2015).

Todavia, a mudança paradigmática na legislação condicionava uma mudança estrutural nas formas de atenção à relação juventude e práticas ilícitas, uma vez que, os equipamentos do Poder Público, historicamente responsáveis por estas questões, houveram se constituído sob a égide das normativas anteriores, as quais reservavam a este público Práticas Institucionais que perpassavam pela segregação ou pela irregularidade da situação em que a lei inscrevia estes adolescentes.

Esta convivência de dois modelos de justiça juvenil, um ligado aos Códigos de Menores das décadas de 60 e 70 do último século e outro mais recente, advindo de nossa última Constituição Federal de 1988, ainda era uma realidade perceptível nas Instituições que atendem adolescentes em conflito com a Lei nas primeiras décadas deste século. Tal constatação se origina de uma experiência profissional, realizada no período de 2012 a 2014, na qual pude ocupar a função de técnico em medidas socioeducativas, num equipamento vinculado ao Centro de Referência Especializada em Assistência Social (CREAS) da cidade de São Paulo. Antes de detalhar este percurso profissional apresento uma breve retomada histórica da legislação que regula a função do técnico.

Ainda que, desde o ano de 1993 a Lei Organica da Assistencia Social - LOAS já defendesse o caráter de política pública de âmbito nacional para as ações de Assistência e 
Desenvolvimento Social, fora somente no ano de 2004, com a Política Nacional de Assistência Social - PNAS e no ano seguinte com a implementação do Sistema único de Assistência Social (Brasil, 2005) que, o desenho organizacional da política pública de Assistência Social inicia seu percurso de adequação estrutural à perspectiva de garantia de direitos, na qual os Centros de Referencia da Assistência ganham sua materialidade.

Na perspectiva de viabilizar a implementação do desenho constitucional, a PNAS dividiu as ações da Assistência social em dois níveis; proteção social básica e proteção social especial. A primeira tem a responsabilidade de atender pessoas em situação de "vulnerabilidade social e destina-se ao desenvolvimento de ações que visem ao fortalecimento dos vínculos sociais e o desenvolvimento de potencialidades” (Brasil, 2005). Já a segunda, a qual inclui o atendimento à adolescentes em conflito com a lei, têm por atribuição intervir junto a pessoas que estão em situação de risco pessoal e social, por ocorrência de abandonos e maus-tratos físicos e, ou, psíquicos, abuso sexual, uso de substancias psicoativas, cumprimento de medidas socioeducativas, situação de rua, trabalho infantil entre outras (Brasil, 2005).

Na capital paulista as ações de Proteção Social Especial, referenciadas aos CREAS tal como prevê a legislação Federal, são executadas na ponta por Organizações não governamentais, a qual tem por atribuição a contratação do quadro de funcionários bem como o atendimento doas adolescentes e jovens remetidos pelo Poder Judiciário. Estas organizações trabalham na modalidade de convenio com a Prefeitura de São Paulo, junto a diferentes populações atendidas pelas políticas da Assistência Social. Esta perspectiva de atuação na administração pública de maneira indireta já foi discutido por ... Assim medidas socioeducativas em meio aberto, Prestação de Serviços à comunidade e a medida de Liberdade Assistida, são acompanhadas por Associações Comunitárias ou Organizações Sociais que assumem esta demanda no município. Nos casos de medidas de internação ou semi-liberdade é o Poder executivo estadual que responde por estas ações, por meio de uma Fundação específica concebida para este fim.

E é neste ponto que se inicia minha trajetória no fenômeno da adolescência e as práticas infracionais, atuação profissional que iniciei com ainda menos informação tal qual a apresentada até o presente momento nesta introdução. Neste sentido, este relato seguirá em paralelo à 
reconstrução de parte da história recente das políticas socioeducativas, uma vez que a compreensão que embasa este estudo é fruto de um processo de imersão no campo que ocorreu quase que concomitante a evolução das legislações e das práticas no quadro das políticas para Infância e Juventude, em especial na capital do estado mais populoso do país.

A lei 12.594 do SINASE em seu artigo $12^{\circ}$ regula sobre as equipes técnicas de atendimento para adolescentes em cumprimento de medida socioeducativa, destacando o caráter interdisciplinar do programa com profissionais das áreas de saúde, educação e assistência social (Brasil, 2012). Mas é o ECA (Brasil, 1990) que melhor apresenta os objetivos da atuação técnica junto a adolescentes aos quais, em razão de sua conduta, necessite de medidas específicas de proteção. Segundo a Lei 8.069 considera-se ato infracional toda conduta prevista como crime ou contravenção penal, praticada por aquele com idade entre 12 e 18 anos incompletos. No artigo 112 da mesma Legislação encontramos as medidas aplicáveis pela autoridade competente, neste caso o Juiz da Vara da Infância da Comarca Jurisdicional a qual ocorreu o fato, considerando a gravidade e a natureza da ação delitiva. Assim podemos dividi-las entre sanções aplicáveis em regime de internação e semi-internação e aquelas que devem ser cumpridas em meio aberto, das quais já apresentamos brevemente quando falamos da especificidade desta política no município de São Paulo.

Sendo assim, o profissional que atua em medidas socioeducativas de Prestação de Serviços à Comunidade e Liberdade Assistida recebe aqueles que, por força de Lei, praticaram atos infracionais de menor poder ofensivo, ou que não tenham sido praticados mediante violência ou grave ameaça, uma vez que, excepcionalmente nestes casos, é prevista medidas mais gravosas, tal como a medida de semiliberdade e internação, como sanção ressocializadora (Brasil, 1990). Cumpre apontar que esta informação não me era tão clara em maio de 2012 quando iniciei meu percurso profissional no acompanhamento das medidas socioeducativas. Assim, após um período de treinamento e observação a atuação dos outros profissionais que desempenhavam esta função, recebi para atendimento o primeiro adolescente encaminhado pelo Departamento de Execuções da Infância e Juventude de São Paulo - DEIJ-SP para cumprimento de uma medida em meio aberto. Neste curto tempo de contato com a realidade da adolescência em conflito com a lei, circulava ainda em minha compreensão muito do entendimento ofertado pelo senso comum, da 
periculosidade dos jovens periféricos, das relações com o tráfico de drogas e da infração. (Romanini, Roso, 2013).

Tal qual grande parcela dos adolescentes apreendidos, este jovem que procurou o Serviço municipal da política socioeducativa no ano de implantação do SINASE houvera recebido uma medida socioeducativa de Liberdade Assistida, decorrente de um ato infracional de roubo. Destaco que a lembrança de alguns detalhes do ato infracional que gerou o processo necessitou um esforço de recapitulação de quem subscreve, uma vez que hoje, quando relembro minha atuação junto a este adolescente, é a relação que estabelecemos a lembrança que retorna com maior intensidade.

De todo modo, o procedimento de ingresso dos adolescentes no campo da execução das medidas pelos entidades responsáveis permaneceu o mesmo desde minha chegada até os últimos contatos que tive com este campo de atuação. Na verdade, a promulgação da lei 12.594 já houvera provocado uma alteração nos protocolos do atendimento com o advento do Plano Individual de Atendimento decorrente desta legislação e da qual tratarei em especifico mais adiante, me refiro aqui a um processo anterior, a qual se inicia com o fim do processo de apuração e desdobra nas diversas modalidades de execução das sanções socioeducativas. Todo adolescente que adentrava o Serviço de Acompanhamento de medidas em meio aberto trazia em mãos um ofício de encaminhamento do Departamento de Execuções da Infância e da Juventude de São Paulo, com algumas informações pessoais do adolescente e seus genitores, o Juiz da Infância que julgou o ato e a sanção aplicada.

A duração da sanção pedagógica tinha como prazo de duração o limite máximo de seis meses e incluía também medidas protetivas previstas no artigo 101, inciso III do ECA, a saber, matrícula e frequência obrigatória em estabelecimento oficial de ensino. (Brasil, 1990). Muitos dos outros Ofícios que recebi de adolescentes no tempo que atuei com Medidas Socioeducativas vinham com este aditivo indicando a necessidade de atenção maior a esta dimensão da vida do adolescente. Existiam outras, tais como inclusão em programas e serviços oficiais ou comunitários de apoio ao adolescente e sua família ou auxílio, orientação e tratamento de 
alcoólatras e toxicômanos (Brasil, 1990). Todavia, a questão das drogas e a questão educacional foram a grande maioria das medidas protetivas aplicadas no período em que atuei.

Ocorre que este meu primeiro adolescente atendido também teve um percurso escolar acidentado. Lembro que abordar este tema em atendimento era provocar um momento de constrangimento, um rompimento em seu relato eufórico sobre seu ato ilícito e sua afirmação no meio delitivo enquanto marca de uma identidade. Para ele falar de sua vida loka era muito mais interessante e próximo do que tratar de ensino e retomada da vida escolar (Lazzarotto, 2014; Malvasi, 2011). A medida que tomava conhecimento das vicissitudes da atuação profissional de técnico um panorama mais completo da questão educacional presente no fenômeno fora se delineando, permitindo que não elegesse culpados nas Instituições de Ensino ou nos meninos que se evadiam da escola, existia sempre um contexto na situação e a situação em seu contexto como já ouvira de uma professora da pós-graduação.

A região leste de São Paulo, juntamente com a região Sul da cidade concorrem entre aquelas que possuem os bairros com os mais altos índices de violência registrados. Num estudo sobre o mapa da criminalidade na capital paulista, promovido por um Instituto associado à Fundação Armando Alvarez Penteado no ano de 1999, alguns bairros do extremo leste da cidade já aparecem com índices alarmantes de roubos e homicídios (Filho \& Netto, 1999). Em comum, estes extremos territoriais de violência têm como marca a carência generalizada de serviços públicos e a desatenção estatal a direitos fundamentais tais como Educação, cultura, lazer e saúde, coincidentemente os principais eixos de intervenção a qual o técnico que acompanha a medida terá de intervir.

No caso específico o juiz da infância houvera decidido quanto a necessidade de retomada da escolarização deste jovem e sua inserção no mercado de trabalho. o adolescente da qual retomo a história houvera abandonado a escola ainda no início do Ensino Fundamental, segundo pesquisas, o perfil dos adolescentes que ingressam o sistema socioeducativo tem por predominância a baixa escolarização e a evasão escolar como marcas.

Quanto a profissionalização, nosso protagonista estava prestes a completar 16 anos e tivera algumas poucas experiências profissionais com construção civil na função de ajudante, 
uma das colocações profissionais mais recorrentes entre os meninos, concorrendo com o trabalho em lava-rapidos, ocupações informais que não eram consideradas atividade laborativa formal pela justiça juvenil, o que tornava a grande maioria dos adolescentes atendidos desempregados ou sem experiência profissional aos olhos da justiça.

Como já apontado, dentre as muitas inovações que a Lei Federal 12.594 trouxe para os procedimentos de execução de medidas socioeducativas, uma das mais significativas fora a adoção de um instrumento particular e programático de diagnose e intervenção junto a cada adolescente atendido por esta política pública, o Plano Individual de Atendimento PIA. Assim mais uma vez, meu percurso profissional na área da Infância coincide com a adoção de novos referenciais metodológicos e novos instrumentos de intervenção, mais alinhados com a proposta da garantia de direitos. Segundo seus defensores, uma das principais evoluções do PIA é este seu caráter singular, elaborado a partir das necessidades e peculiaridades de cada adolescente ou jovem e, fundamentalmente, construído em conjunto com ele, a partir de seus objetivos, suas necessidades e suas intenções, alinhando-se assim ao protagonismo pretendido pelo ECA e pela Constituição Federal de 1988.

Prosseguindo a narrativa sobre este primeiro adolescente a qual acompanhei em seu processo socioeducativo, relembro que em seu Plano Individual de Atendimento pactuamos como metas em sua medida de Liberdade Assistida os seguintes objetivos: documentação, escolarização e profissionalização, respectivamente nesta ordem de intervenções. A regularização de documentos oficiais de identificação era prática comum entre as funções dos técnicos no acompanhamento da medida. Muitos adolescentes atendidos nos MSE, em especial aqueles vindos das regiões mais periféricas do território de abrangência do equipamento, tinham seu primeiro contato com ações Estatais de garantia de direitos fundamentais como saúde, assistência social e profissionalização, quando do cometimento do ato infracional e consequentemente, da construção de seu Plano Individual e Atendimento, quando estas demandas eram visibilizadas (Lazzarotto, 2014).

A questão da retomada da escolarização, indicada na decisão judicial, era então o principal desafio para o profissional da ponta desta política pública. A articulação com outras 
pastas Estatais era prerrogativa do trabalho técnico. Estabelecer junto a rede de ensino, o retorno do jovem em cumprimento de medida aos bancos escolares era assim uma ação de resgate de direitos, mas ao mesmo tempo, uma condição para o encerramento da medida determinada pelo Juiz da Vara da Infância. Aqui tem início, um dos principais desafios da profissão e da intervenção socioeducativa, expressa pelo preceito constitucional da Incompletude Institucional. Muitos autores já discutem há um algum tempo sobre a rede socioassistencial e seu papel na efetivação da Política Pública de Assistência Social, mas creio que o contato com diferentes profissionais de diversos serviços governamentais tenha sido a forma mais clara de compreensão desta estratégia e seu aspecto primordial na efetivação das ações.

Em , naquilo que se refere às articulações com a Educação, aponto que tenho hoje uma compreensão que na época ainda não me era tão nítida. Assim, esta inserção na rede de ensino fora neste, e em muitos outros Planos Individuais de Atendimento, uma das tarefas mais árduas, uma vez que o dialogo com as unidades de ensino era sempre uma atividade imprevisível. Em alguns casos, o desconhecimento dos direitos da infância e das praticas socioeducativas era o primeiro obstáculo a ser superado. Em outros, o preconceito era apresentado ainda na solicitação de vaga, pela estigmatização enredada no uso pejorativo da abreviação da medida de Liberdade Assistida, a LA, como sigla de identificação dos adolescentes, assim já não eram João, Pedro ou Matheus, mas sim os "LA”. Todavia, diante a determinação expressa da Justiça a matrícula dos adolescentes era realizada, o que não significava o sucesso da intervenção uma vez que ainda restava o desafio da permanência.

E assim ocorreu com este meu primeiro caso, como também eram chamados os adolescentes e jovens no cotidiano dos MSEs. Sua matricula fora realizada num Centro Integrado de Educação para Jovens e Adultos - CIEJA, equipamento escolar responsável pela oferta de ensino supletivo para aqueles em faixa etária superior a idade recomendada para a seriação oficial. Em geral, os adolescentes retomavam sua escolarização em alguma etapa do Ensino Fundamental, com algumas exceções no ensino médio. Mas o longo período de afastamento e, o que viria a se tornar recorrente, uma primeira experiência ruim de contato com a escola era responsável por uma alta taxa de evasão neste processo de retomada da escolarização. 
Concluindo o relato sobre esta minha primeira intervenção na política socioeducativa, admito que não posso afirmar quanto ao sucesso da medida ou quanto aos seus efeitos na vida de nosso adolescente, uma vez que poucas semanas após a inserção na escola, a genitora do adolescente acaba por mudar de bairro, indo morar com alguns parentes próximos em outro bairro da zona leste de São Paulo, o que segundo a legislação socioeducativa, transfere o acompanhamento da sanção para o MSE de referencia no novo bairro ao qual o adolescente irá residir.

Ao mesmo tempo, a Secretaria Municipal de Assistencia e Desenvolvimento Social SMADS e o Departamento de Execuções de Infância da capital paulista, alinham seus esforços na adequação das praticas socioeducativas às prerrogativas da Lei 12.594, na direção do aprimoramento das ferramentas trazidas pelo texto legal, em especial na construção do PIA. Na pratica, o sistema de justiça impugnava os planos que eram elaborados em desacordo com as normativas legais, devolvendo aos serviços de origem para retificação ou inclusão de pontos específicos. A SMADS cumpria seu papel de gestão nos Equipamentos que apresentavam maior frequência de impugnações.

Após alguns meses de uso da nova metodologia, os equipamentos passam a desenvolver um ritmo de trabalho entre aquilo que pressupõe a legislação e as ações concretas nos MSE’s. Do mesmo modo, exerci minhas funções com muitos outros adolescentes nos dois anos que seguiram a implementação da Lei do SINASE, ouvindo estórias de vida e versões sobre o fato que o levara até ali, articulando rede para a efetivação de direitos e acompanhando adolescentes e pais em audiências no DEIJ, cumprindo o papel do especialista no rito de execução da medida.

As audiências no Fórum do Brás eram em sí um aspecto a parte na atuação do técnico de medida socioeducativa. No contexto da execução da medida era a possibilidade de contato direto com outros atores do sistema de justiça, a saber, Promotores e Defensores Públicos e os Juízes das Varas da Infância. Até o presente momento deste percurso profissional, a participação dos operadores do direito nos processos socioeducativos se limitava a prescrições expressas nos documentos das que compunham as pastas técnicas dos adolescentes. 
Aqui me refiro a pasta técnica como o conjunto de documentos gerados por um ato infracional e obrigatórios em cada processo socioeducativo. Em geral, estes documentos se apresentavam tal qual um prontuário ou uma pasta de arquivos e era encaminhado para os MSE’s para a realização do acompanhamento técnico das sanções. Em sua maioria, iniciava com a Representação do Ministério Público, que consiste na transcrição da Oitiva informal do adolescente ou jovem pelos Promotores do DEIJ, acerca dos fatos delitivos, na qual o operador do direito avaliava a necessidade de abertura de um processo. Seguia-se o ofício que relatava a audiência de apresentação, a qual um juiz das Varas de Apuração julgava a procedência do pedido realizado pelo Promotor Público, agora com a presença do Defensor Público, seguindo assim as disposições do texto legal, que buscam assegurar a garantia de ampla defesa do adolescente a qual se atribui uma conduta infracional.

O resultado desta audiência determinava os documentos subsequentes, embasadas claro na aplicação da Legislação Constitucional. Neste ponto cumpre retomar algumas premissas do Estatuto naquilo que se refere à Proteção Integral. Perspectiva que considera a ação delitiva como uma ação que demanda reparação mas que, ao mesmo tempo, é entendida como uma violação de direito. Ou seja, a sanção elegida pelo Juiz da Infância deve, ao mesmo tempo, responsabilizar e ter caráter educativo.

Quanto ao aspecto físico, creio que cada estado da Federação deva apresentar peculiaridades quanto a estrutura dos Tribunais e das salas de audiência de seu território, mas a priori todas elas atendem um aspecto comum, a existência de uma hierarquia de posições entre os assentos que integram o cômodo, disposição esta que esta intimamente ligada à condução do processo. A cadeira do juiz deve ocupar sempre uma posição superior, seja com um degrau ou por um patamar que indique esta elevação. Os demais lugares devem se alinhar na mesma disposição em torno do magistrado, com o Promotor e o Defensor mais próximos do Juiz, e o adolescente, seus familiares e os técnicos que o acompanham, seja nas medidas em meio aberto ou em meio fechado, nas posições opostas ao magistrado. (Scisleski \& Guareschi, 2011)

Sob a perpectiva de um leigo no campo do direito, o ritual também não apresenta muitas variações, o juiz inicia pela leitura ou retomada dos fatos que ensejaram o processo e pela 
indicação pela qual o Ministério Público decidiu na Oitiva Informal, em seguida cede a palavra para os demais operadores de Justiça afim de que apresentem verbalmente as razões que embasam suas posições. Em geral Promotores reforçam suas representações e defensores buscam reverter ou apresentar versões que apontem o equivoco dos pedidos de sanções mais gravosas.

Em atos com potencial mais ofensivo, em que o ECA determina a necessidade de internação como medida socioeducativa, este embate se da na direção da desqualificação da versão inicial, ou mesmo do Boletim de Ocorrência. Como testemunho pessoal, no período em que atuei no Sistema Socioeducativo, não me deparei com audiências de apresentação as quais houvesse o relato de grandes embates entre as partes. Na quase totalidade dos processos existia uma ritualidade processual na qual não se questionava a representação do Promotor e o Juiz acolhia a denúncia com pequenas alterações.

Todavia, as audiências também ocorriam ao curso da medida, seja para uma advertência ou para uma decisão por extinção da sanção socioeducativa. Quando a decisão inicial era por uma medida de semi liberdade ou internação, os adolescentes ou jovens eram então encaminhados para as unidades provisórias próximas ao prédio do Fórum no bairro do Brás. Conforme disposto no Estatuto, esta apreensão inicial poderia ter a duração de até 45 dias, após este período era realizado uma nova avaliação na qual se decidia pela continuidade da sanção ou por sua extinção. Esta decisão se embasava num outro documento que também compunha a pasta técnica dos adolescentes, o Relatório Polidimensional realizado pelos técnicos da Fundação de Atendimento Socioeducativo CASA, Instituto ligado ao Governo estadual e que tinha por responsabilidade a execução das medidas de Semi liberdade e Internação no estado de São Paulo.

Quando da chegada do adolescente ao Centro de Internação, uma equipe multidisciplinar realizava uma avaliação individual de cada adolescente ou jovem, esta avaliação gerava um relatório sobre suas condições no momento do ingresso de modo a indicar suas demandas psicossociais que, de alguma forma, contribuíram para o ato infracional em questão. O protocolo de avaliação se iniciava com o laudo psicológico, prosseguia com a avaliação do profissional de Serviço Social, na sequencia vinha uma avaliação do nível de ensino do adolescente, uma avaliação quanto a aspectos de saúde e encerrava com uma avaliação referente a aspectos de 
Segurança do reeducando. Após as avaliações individuais, era construído um parecer quanto as necessidades do adolescente e a direção das intervenções necessárias. Assim, conforme pressupõe a CF1988, este documento deve apresentar um aspecto singular para cada adolescente ou jovem que ingressa nas medidas mais gravosas e, após o período determinado na decisão inicial, contribuir para a tomada de decisão dos atores do Sistema de Justiça a fim de indicar o encerramento da sanção e a devolução da liberdade do adolescente ou decidir pela prorrogação da apreensão a fim de que se realizem as ações que não foram alcançadas.

Em alguns casos, grande parte indico por experiência própria, a medida de internação era seguida por outra medida em meio aberto, uma medida de Liberdade Assistida ou de Prestação de Serviços à Comunidade. Assim, nestes casos, a pasta técnica do adolescente continha, além dos relatos jurídicos do ato, este relatório polidimensional realizado quando da sanção em meio fechado. Todavia o protocolo indicava a necessidade de realização de outra avaliação multidisciplinar, agora pelos profissionais dos MSE's e com metas adequadas para o meio aberto.

O fluxo de acompanhamento das medidas em meio aberto seguia um padrão em sua realização que possibilitava um primeiro contato dos técnicos com os adolescentes e suas versões dos fatos para, num momento posterior, o acesso aos dados do processo socioeducativo relatado acima. Assim, o conhecimento do adolescente, a retomada de seu ato infracional e as primeiras indicações de metas eram elaboradas sem os dados destes documentos, que chegavam aos MSE's cerca de duas semanas após a apresentação dos adolescentes nos serviços em meio aberto.

A percepção dos ritos de audiência gerava, a cada nova experiência, uma sensação de descontinuidade. Em sua grande maioria o engessamento dos procedimentos não abria espaço para a opinião técnica. Quando éramos instados a falar sobre nosso acompanhamento da medida em geral o tom da exposição era na linha de um exame. Os atores da Justiça inquiriam os fatos relatados como se na busca por brechas ou falhas em sua construção. A compreensão dominante entre meus colegas técnicos era de que se precisava construir um relato de convencimento, na qual aspectos da vida dos adolescentes eram validados apenas quando enquadrados nas metas propostas pela determinação judicial. Se o adolescente estudava, se trabalhava ou se buscava algum curso profissionalizante eram as indagações mais recorrentes, seguidas por determinados 
aspectos do relacionamento familiar e a continuidade da relação com o meio infracional, estas ultimas, em alguns casos, dirigidas também as genitoras dos réus, em poucos casos, para seus genitores.

A impressão que se fortalecia diante as situações de audiência era de que estes relatos não apresentavam o mesmo tom de legitimidade das falas da Justiça, em especial do Promotor e em especial, do Juiz. As alegações dos Defensores em poucas ocasiões provocavam mudanças nos rumos das audiências, o que alimentava um sentimento de receio diante cada nova intimação que chegava do Fórum do Brás.

Deste modo, o que nos assegurava nestas situações eram os fatos relatados nos relatórios trimestrais. Após o PIA, em que se informava ao juiz as metas pactuadas com o adolescente na direção de sua ressocialização, o andamento destas ações deviam ser informados em documentos timbrados, elaborados pelos profissionais de referencia de cada adolescente, direcionados a informar o andamento e o sucesso das ações previstas.

Nas situações de audiência estes relatórios eram retomados e verificados in loco pelo Juiz ou pelas partes envolvidas no processo. Em alguns casos, estas informações eram confirmadas junto ao adolescente ou a seu familiar, na garantia do cumprimento da medida tal qual ela foi imposta pelo Juiz. Ainda que a literatura aborde já a algum tempo a questão da discricionariedade de Juízes de menores, esta experiência profissional contribuiu decisivamente para que o interesse pelo aprofundamento no tema, na pesquisa de campo começasse a surgir neste narrador.

Neste sentido, a percepção, a postura e as peculiaridades de cada magistrado, na execução de seu ofício de julgar, passaram a me inquietar cada vez mais. Numa dessas experiencias um Juiz, a qual já possuía uma relativa fama de severo entre os técnicos que participavam de suas audiências, confirmou os boatos a seu respeito de um modo que me marcou profundamente. Era uma audiência de advertência para um adolescente visando sua retomada ao cumprimento de sua medida de Prestação de Serviços à Comunidade. Em dado momento de sua exposição, após ouvir os técnicos, uma vez que o adolescente em questão não comparecera a sua convocação, o magistrado passou a indagar nós profissionais quanto a eficácia e a pertinência da atividade em que o adolescente fora inserido para cumprimento de sua sanção. Tratava-se da 
Oficina de Grafite, na qual um oficineiro contratado pela Organização que acompanhava os adolescentes, realiza a pintura de telas, muros ou paredes em outras Instituições parceiras que cedem o uso de seu espaço.

Lembro claramente do Juiz manifestar seu descrédito quanto a esta atividade sugerindo em seu lugar outras atividades que exigissem mais esforço braçal do jovens. A oficina em questão era uma das atividades mais concorridas pelos jovens para cumprimento de suas sanções, tendo a vantagem de ocorrer com maior proximidade dos serviços e dos técnicos, uma vez que todas as saídas eram supervisionadas por um técnico de referência. Em geral, estas medidas eram cumpridas em equipamentos da própria rede de serviços da Assistência Social, a qual aceitavam receber o adolescente para a prestação de um dado serviço em seus espaços. Ocorre que este aceite é voluntário por parte das Instituições, cabe ao gestor ou responsável avaliar e aceitar a parceria. Lembro também das reuniões que o Serviço de medidas socioeducativas realizava entre seus parceiros a fim de apresentar seu trabalho com os adolescentes e jovens, a fim de que os índices de recusa diminuíssem nesta tarefa.

Segundo a legislação esta tarefa deve atender aos interesses e peculiaridades do adolescente, uma vez que a proposta do serviço comunitário se inscreve num processo de ressocialização que propõe o adolescente como protagonista por suas ações e escolhas, seja para sua responsabilização ou para construção de seus novos projetos de vida.

Esta fora apenas um exemplo das percepções contrárias que encontrei neste período em que atuei e estive imerso na política socioeducativa, em específico nas práticas da Justiça Juvenil. Em outras situações, decisões que vinham do Departamento de Execuções, da Defensoria ou mesmo do Ministério Público utilizavam de seu papel fiscalizador para cobrar a execução de Políticas Públicas e consequentemente a garantia de direitos violados pelo Poder Público ou em decorrência de sua omissão. Todavia este mosaico de relatos, compreensões e fatos jurídicos me inquietava de tal maneira, que a atuação profissional não era mais suficiente para meus anseios de investigação e intervenção neste tema. Assim era necessário prossegui estes questionamentos por outras Instituições, alinhavar outras colaborações na perspectiva de que, ainda que esta 
empreitada resultasse numa parcela reduzida de respostas, pudesse ao menos ajudar a evoluir a questão para novas perguntas. 


\section{Juventude(s)}

Neste texto apresento meus protagonistas, ou ao menos, àqueles para os quais todas as discussões confluem, o adolescente/jovem de nosso momento histórico. Segundo definição da Organização Pan-americana de Saúde, órgão ligado à Organização Mundial de Saúde (OPM/OMS), juventude é uma categoria sociológica A escolha por um capítulo especifico para marcar a concepção de adolescência e juventude adotada pelos autores vai além da estrutura de construção narrativa do presente estudo, mas consiste também numa posição política de não reafirmar um estigma de tratar o adolescente ou jovem pela via da criminalização, do contexto da violência ou da periculosidade, ainda que numa produção que se pretenda denunciar estes situações. Entendemos que falar deste jovem, buscando se aproximar ao máximo de suas condições materiais de constituição subjetiva, a qual vão muito além dos fenômeno aos quais a Sócioeducação se inscreve também é um ato de resistência, de afirmação da vida e de resgate da cidadania.

Partilhamos de uma posição consensual entre muitos pesquisadores que afirmam não ser possível se falar num conceito universal de juventude ou adolescência, mas sim em várias juventudes e adolescências, uma vez que cada uma dessas possibilidades de subjetividade juvenil esta atrelada ao contexto social, cultural, econômico e político de cada sociedade em cada momento histórico (Takeuti, 2012). Nessa perspectiva a juventude da qual falaremos é aquela que reside nas periferias das cidades, aquela que partilha das mesmas condições materiais de precariedade e restrição de direitos, comuns a muitos outros jovens residentes nos bolsões periféricos de toda a América Latina.

Assim, falar deste recorte da população jovem por uma narrativa que não os situe na posição de autores nos fenômenos da violência ou do crime se torna uma tarefa de resistência, uma vez que, segundo o Atlas da violência de 2017 divulgado pelo Instituto de Pesquisas Econômicas e Aplicadas (IPEA), do total de óbitos registrados no período analisado, 47,58 \% do 
total correspondem a assassinatos de homens do sexo masculino com idade entre 15 e 29 anos (IPEA, 2017). Nesta perspectiva, optamos por desenvolver um relato que se aproxime dos adolescentes e jovens em suas potencialidades e expectativas mais do que em seus índices de vulnerabilidade e risco, uma vez que, este panorama também têm servido a um discurso que legitima o estigma e a exclusão, seja pela via da autoria ou do contexto social. Desde a última década do século XX, nunca se falou tanto sobre a condição do indivíduo jovem nos países sulamericanos, seja por sua diversidade cultural, suas formas de organização ou por seus modos de inserção comunitária. Ao mesmo tempo, profundas transformações sociais, políticas e econômicas, que vem ocorrendo nestes países latino americanos, desvelam as muitas semelhanças entre os jovens destes países (Takeuti, 2012).

No ano de 2010 o Instituto Brasileiro de Análises Sociais e Econômicas, em parceria com o Instituto Pólis, lançou o Livro das Juventudes Sul-americanas, a qual teve por objetivo promover o diálogo entre os países do bloco sul da América Latina (Brasil, Argentina, Paraguai e Uruguai) na direção de construir uma cidadania regional entre este recorte etário da população. Esta publicação ilustra este avanço do olhar sobre adolescentes e jovens na região, todavia, também revela a marca dos determinantes materiais que condicionam a constituição subjetiva de nossa população de pesquisa, aos quais são comuns entre os jovens da maioria dos quatro países da publicação. Estas condições objetivas tais como a desagregação social herdada de Governantes autoritários e as políticas neoliberais recentes, as quais acompanhadas do acelerado processo de globalização das últimas décadas aguçam as desigualdades e os processos de exclusão nestes países, entretanto neste mesmo período o Livro destaca o aumento das praticas de participação, associativismo e redes sociais como instrumentos de integração do jovem ao processo democrático. (IBASE, 2010).

No ano de 2013, em diversas capitais do país, um fenômeno pouco comum na recente história da redemocratização brasileira reacendeu o debate sobre participação política e juventude na contemporaneidade. Por razões diversas, mas em grande parte aglutinadas em torno da reinvindicação por melhorias nos serviços públicos ou politicas públicas incompletas, contra os Governantes e os modos culturalmente aceitos de se fazer política no Brasil ou mesmo por outros espaços de luta e discussão, considerando o papel das redes sociais na comunicação e logística 
dos eventos (Araújo, 2015; Duarte, 2016). Uma pesquisa encomendada pela Secretaria Nacional da juventude, ainda no ano de 2013, revelou que cerca de 45\% dos jovens ouvidos acreditam que manifestações públicas são capazes de melhorar a situação do país. A mesma pesquisa também revelou que dentre os principais desafios para esta melhoria estão a corrupção, indicado por cerca de $67 \%$ dos entrevistados seguido pelo temor quanto ao poder dos traficantes, apontado por $46 \%$ dos ouvidos (G1, Portal Globo de Notícias, 2013).

Essa associação entre militância e juventude remonta a um modelo de compreensão desta faixa etária que se consolidou na segunda metade do século XX. Na academia, as pesquisas que buscavam investigar o comportamento social dos jovens nas décadas de 1960 e 1970 tinham como população alvo jovens de classes sociais mais privilegiadas, em geral, estudantes universitários. Os movimentos estudantis, juntamente com a noção de uma mobilização política capitaneada por jovens de estratos sociais mais elevados constitui uma das representações sociais mais estabelecidas quanto as formas de participação política dos jovens (Dias \& Souza, 2015; Duarte, 2015).

Os adolescentes e jovens que são engendrados no Sistema Socioeducativo, em sua grande maioria, se situam em classes sociais mais baixas e marginalizadas de direitos fundamentais tais como Educação básica e Fundamental, logo, se afastam da identidade politicamente rebelde da juventude. A prática profissional com este público também revela este distanciamento, em especial na Socioeducação, na medida em que, diante uma proposta de educação social pautada por uma concepção liberal e não crítica de Ensino e Sociedade, se perceba a ausência da escola enquanto Instituição formadora e emancipadora na vida destes adolescentes e jovens (Zanela, 2012; Saviani, 1980).

Nas décadas de 1980 e 1990 os estudos acadêmicos passaram a se concentrar nesta parcela populacional da juventude e a atenção se voltou para questões de vulnerabilidade e exclusão social, as quais são urgentes no cotidiano desta juventude, em contraposição à tomada de consciência, à participação democrática e mobilização estudantil que os estudos sobre gerações anteriores apontavam (Dias \& Sousa, 2015). Todavia, esta ausência de organização política não representa uma passividade diante os determinantes sociais que condicionam sua 
realidade. Como apontamos, para muitos pesquisadores esta associação frequente entre condições de exclusão e estratos sociais mais baixos representa, em sua reiterada afirmação, mais um dispositivo de exclusão de marginalização que uma constatação pretensamente científica (Wacquant, 2001; Junior, 2012).

A convivência com um Estado Democrático de Direito, que se efetivou mais na norma que na prática real, obrigou esta população a investir em outros caminhos de resistência e rebeldia, aos quais se revelam contundentes na tomada de posição e relativizam a assunção da consciência crítica. O discurso corrente da cidadania incompleta e da necessidade de reinserção social funciona, para estes jovens, mais como aspecto que ressalta a necessidade do desenvolvimento de uma razão própria e adequada à incerteza e ao risco de uma existência material condicionada pelas vicissitudes do convívio com omundo do crime e com a ambiguidade de práticas Institucionais por parte do Estado. Nesta perspectiva, o Universo das práticas criminais nas periferias ou franjas da cidade vai além do simples aspecto da legalidade ou da norma social e a "Vida Loka", distintivo de um modo de vida que é atravessado pela transgressão, parece mais querer representar o imponderável da experiência comum a qual cada indivíduo residente na periferia deve gerir num cotidiano de complexidades a qual o Governo ou qualquer outra força social tem poder de limitar (Malvasi, 2011; 2015).

Para estes estes adolescentes e jovens residentes nas periferias, em especial para aqueles que carregam a especificidade da marca institucional do conflito com a lei, a fluidez e a efemeridade que resultam destas condições materiais são parâmetros para o exercício da subjetividade, ou ainda, inscreve as possibilidades de escolha desta juventude entre a permanência na fugacidade e ostentação da arriscada vida no crime ou a aceitação de uma vida sem perspectiva, condenada a postos profissionais subalternos alijados do consumo de bens socialmente desejáveis. (Malvasi, 2011). Este ponto de tomada de decisão entre dois caminhos também se reflete no cotidiano profissional com estes adolescentes, quero dizer, a relação profissional que se estabelece entre os trabalhadores da ponta do sistema socioeducativo, e seu público alvo, também deve necessariamente se iniciar por um constructo que busca, dentro da Doutrina da Proteção integral, oferecer as ferramentas para a opção adequada dentro desta corrente juridica. 
Da experiência pessoal de atuação no campo acrescento que umas das principais atribuições do técnico em medida socioeducativa, senão a mais importante, se refere a promoção da capacidade de adolescentes e jovens para o exercício da criticidade. Calissi e Silveira (2013) definem este conceito como produto inerente a processos educativos, como uma das competencias mais específicas da condição humana a qual lhe concede a capacidade de realizar um exame de suas condições de vida de modo a submete-las à análise na direção de encontrar soluções e propor projetos de mudança. Noção advinda das garantias constitucionais do Estatuto da Criança e do Adolescente (Brasil, 1990) esta competência subjetiva revela a Cultura de Garantia de Direitos expressa nesta legislação. Busca assegurar o respeito a dignidade de adolescentes e jovens ao mesmo tempo que reconhece a especificidade da situação peculiar de desenvolvimento desta faixa etária (Calissi \& Silveira, 2013).

Deste modo, se para o adolescente ou jovem residente nos bolsões periféricos das cidades, onde organizações criminosas transnacionais atuam cotidianamente ocupando espaços deixados pela presença do Estado, o desenvolvimento de uma "mente”, a qual poderia ser um correlato da capacidade de crítica e exame de sua realidade, representa um símbolo de sucesso e reconhecimento por seus pares, para o aparato Estatal esta competência deixa de existir quando de sua entrada nas engrenagens do Sistema Socioeducativo.

Para alguns autores, a expressão correntemente utilizada pelos adolescentes como "mente" se refere, dentre outras coisas, a um modo de vida que se relacione com o mundo do crime de maneira que isto não lhe impeça o estabelecimento de relações comunitárias e que não represente obstáculos à construção de seu projeto pessoal permeado por seus desejos e objetivos singulares” (Malvasi, 2011, p. 159). 


\section{Sócioeducação e a questão das drogas}

Neste capítulo estabelecemos algumas questões fundamentais para o desenvolvimento deste estudo, no decorrer da presente discussão pretendemos introduzir, entre a questão juventude e criminalidade, um eixo crucial de problematização: a questão das drogas. Apesar do título genérico, me refiro aqui mais à temática do tráfico e da política criminal de substancias ilícitas no contexto do Justiça Juvenil. Todavia para efeito desta tese, entendemos droga como um tipo de mercadoria que satisfaz uma necessidade humana e que se inscreve no circuito de produção, circulação e distribuição das relações capitalistas com a especificidade do valor agregado oriundo da proibição. (Rocha, 2012)

Para nossa discussão, a droga produto, aquela que ocupa um espaço social e cultural nas periferias das grandes cidades e na realidade dos adolescentes atendidos pelas práticas socioeducativas têm menos lugar que a droga mercadoria, aquela que se insere numa lógica de exploração das relações de trabalho e instaura relações de violência por controle e poder nos territórios em que se dissemina (Rocha, 2012. Nessa perspectiva, nos alinhamos a percepção do Sistema penal, para o qual a droga importa mais pelas possibilidades de controle que sua regulação possibilita do que aspectos intrínsecos da substancia em si (Batista, 1997)

Nos últimos anos, as apreensões de adolescentes por delitos ligados ao tráfico de substancias entorpecentes normativamente proibidas pela legislação vigente vem aumentando em algumas regiões do país. Segundo reportagem veiculada pela Folha de São Paulo no ano de 2015, apenas no período que vai de 2002 à 2012, o número de internações de adolescentes pelo ato infracional de tráfico saltou de $7,5 \%$ a $23,4 \%$ do total nacional, de acordo com dados preliminares da Secretaria de Direitos Humanos da Presidência da República e do DEPEN, órgão ligado ao Ministério da Justiça, consolidando esta modalidade de ato infracional como o segundo delito mais frequente, após o crime de roubo. Em cidades como Salvador este número saltou 
1600\% no período que vai de 2006 a 2016, passando de 23 para 414 ocorrências, de acordo com dados da Delegacia do Adolescente Infrator daquela cidade.

Há cerca de dez anos, a socióloga Alba Zaluar já apontava (2007) o caráter perverso das interações que se desenvolveram entre jovens pobres e vulneráveis e a indústria transnacional do trafico de drogas nas ultimas décadas do século XX. Para a autora, o aumento do número de homicídios e criminalidade entre jovens do sexo masculino, neste período que sucede a redemocratização, representa um enigma que só pode ser compreendido numa perspectiva que considere a complexidade de diferentes dimensões; as articulações entre crime organizado internacional, em específico o tráfico de drogas e de armas, e sua relação com os fenômenos da pobreza e da urbanização acelerada nas grandes cidades; a apatia dos sistemas de justiça diante o recorrente quadro de violação de direitos fundamentais e por último os processos subjetivos e microssociais de construção da identidade no universo do crime por parte de adolescentes vulneráveis. (Malvasi, 2011; Zaluar, 2007).

A logística de circulação e comércio de substancias entorpecentes ilícitas é hoje uma das principais questões de nosso tempo, que se materializam nas organizações criminosas transnacionais constituídas para garantir a distribuição destas substancias ao redor do Globo. Todavia o tráfico de drogas corresponde a apenas uma das engrenagens de um sistema que também envolve mercados formais nas relações econômicas que se estabelecem no crimenegócio (Zaluar, 2007). Nas redes estabelecidas no crime organizado transnacional, na qual o tráfico se insere, aqueles que ocupam hierarquicamente funções superiores podem ter rápidos ganhos em razão da existência de poucos limites institucionais, da violência e da corrupção.

Há cerca de vinte anos Vera Malaguti Batista (1998) já discorria sobre a questão do envolvimento da juventude pobre com o tráfico de drogas no estado do Rio de janeiro em sua obra Difíceis ganhos fáceis em que apresenta o resultado de suas pesquisas com documentos jurídicos policiais do período. A autora constata o aumento do ingresso dessa parcela populacional no Sistema de Justiça pela via da infração do tráfico de substancias ilícitas. Eram meninos e meninas, adolescentes e jovens criminalizados pela posse e comércio de pequenas quantidades de drogas ilícitas. Em sua análise, a autora aponta a clara seletividade do Sistema 
Penal observada nos processos que analisou. Quando a apreensão envolvia jovens brancos de classe média é acionado o paradigma médico, de tratamento, todavia quando este envolvia jovens negros de classes baixas, ainda que com a mesma quantidade de substancias, o estereótipo criminal invariavelmente entra em jogo (Batista, 2008).

Neste sentido, ao mesmo tempo que o mercado transnacional de substancias entorpecentes ilícitas ganhava corpo na América Latina nas últimas três décadas, na conjectura da chamada guerra às drogas, imposta pelo governo norte americano na constituição de um novo inimigo interno após o fim do período conhecido como guerra fria (Batista 2015; Carvalho, 2013; Rodrigues, 2004), os arranjos institucionais e as relações sociais no território na qual a economia das drogas se fez presentes também se desenvolveram numa relação de macro e micropolíticas, as quais pretendemos explanar um pouco nos parágrafos que seguem.

O impacto das políticas proibicionistas, como ficou conhecido na literatura o paradigma de atuação Estatal diante determinadas substancias, não somente através de legislações alinhadas com as restrições recomendadas pelas Convenções da Organização das Nações Unidas (ONU, sobre o tema, mas exercendo um papel de conformador do senso comum quanto a classificação de substancias entorpecentes entre legais e ilegais, positivas ou negativas para o consumo (Fiore, 2017). No contexto internacional, o tráfico de drogas representa a atividade ilícita mais rentável do planeta segundo dados do ONUDC, o Escritório das Nações Unidas sobre drogas e crime; No ano de 2005, as atividades relacionadas ao tráfico de substancias entorpecentes ilícitas movimentava cerca de 320 milhões de dólares anualmente, o que colocava a produção, o comércio e a distribuição destas substancias dentre as indústrias mais lucrativas do planeta (Pontón, 2013).

Na passagem da década de 1990 para os primeiros anos do novo milênio, mudanças geopolíticas nos principais mercados consumidores de drogas ilegais impactaram diretamente a América Latina. Se em 1998 os Estados Unidos eram responsáveis por quase 70\% do mercado consumidor de cocaína, uma das substancias ilícitas mais rentáveis para o narcotráfico, dados de 2008, do Escritório das Nações Unidas para Drogas e Crime - ONUDC, indicam que esse mercado passou a representar cerca de $30 \%$ do consumo mundial, ao mesmo tempo que cresceu o 
consumo de substancias psicoativas ilegais nos países da Europa Ocidental e também da América do Sul, exigindo a criação de novas rotas dos países produtores para os centros de consumo. (Pontón, 2013).

O viés da política internacional de controle de drogas ilícitas avançava da concepção medicalizante, que surge na década de 1960 a partir da Convenção Única sobre Entorpecentes realizada pela Organização das Nações Unidas ONU, já com forte influência estadunidense para uma concepção militarizada de enfrentamento da questão, com a justificativa o paradigma médico do prejuízo à saúde física e mental da população supostamente causado pelo uso destas substancias ilícitas o fator de ameaça para a segurança pública nacional e internacional destas atividades. Neste cenário de endurecimento das sanções penais e combate à produção e circulação de determinadas substancias em nome da Defesa Social e da Saúde Pública, diversas legislações se adequaram às premissas proibicionistas no sentido de impedir a produção e o comércio de drogas ilegais e reprimir seus consumidores. (Fiore, 2017; Souza, 2011; Rodrigues, 2003).

No contexto da norma jurídica brasileira, as Leis referentes a crimes envolvendo substancias ilícitas passaram por intensas transformações neste mesmo período. Segundo Carvalho (2013), nossa legislação sobre drogas é marcada por mais retrocessos que avanços em seu percurso, frequentemente na direção de reforçar o caráter punitivo e criminal em detrimento de outras formas de intervenção como o uso de penas alternativas para responsabilização penal. Historicamente a Lei № 4.294 de 1921, bem como suas sucessoras no período, já assegurava exclusividade ao profissional médico no uso de substancias psicoativas, todavia estas regulações não tiveram força em alterar os costumes terapêuticos aos quais estas substancias narcóticas eram utilizadas (Torcato, 2014). Entretanto, o contexto geopolítico advindo da Segunda Guerra Mundial nas décadas seguintes afetou profundamente aspectos econômicos da indústria farmacêutica nacional, substituindo a importação de farmacologia europeia, centrada no uso de opiáceos e demais compostos de origem vegetal, por fármacos sintéticos, majoritariamente produzidos no território norte americano, abrindo caminho para um enrijecimento social e legal quanto ao caráter terapêutico de uso de substancias psicoativas no Brasil: 
No discurso estadunidense, tal medida além de científica - no imaginário dessa época o sintético era superior ao natural pelo simples fato de ser sintético também era humanitária - milhões de pessoas deixariam de ser escravas do vício em opiáceos. O resultado de tal política agradou muito meia dúzia de empresas que passaram a controlar esse ramo comercial, porém do ponto de vista social foi catastrófico (Torcato, 2014, p. 12).

A substituição de uma farmacopeia embasada na utilização do Ópio, da Cannabis e da Cocaína para o alívio da dor por medicamentos sintéticos de eficiência inferior, acabaram por tornar as legislações brasileiras de combate ao uso de substancias psicoativas ilícitas um exemplo de sucesso, uma vez que a criminalidade ligada a produção e ao comércio destas substancias para uso recreativo ainda não era questão nas décadas de 1930 e 1940, porém relatos do crescente hábito de uso recreativo da maconha nos grandes centros urbanos na década de 1950, começa a alterar este quadro de sucesso repressivo da legislação. (Farias, 1958; Torcato, 2014).

Todavia outros aspectos também influenciaram as novas formas de proibição da maconha no Brasil ao longo do último século, em meados das décadas de 1960 e 1970. Se antes deste período o uso da Cannabis era restrito a camadas populares em diversas regiões do país e seu estigma social era de “ópio dos pobres” ou droga de criminosos e prostitutas, o ingresso de frequentadores dos clubes elegantes da Zona Sul carioca no mercado consumidor e os movimentos de contestação e contracultura que influenciavam o país no período alterou significativamente os aspectos culturais de consumo desta substancia. (Velho, 1994, Delmanto, 2013). Deste modo, se antes apenas negros e pobres eram alvos de controle social por meio do estigma atribuído ao uso destas substancias, será nesta época que ocorrerá um maior acirramento do regime repressor às drogas ilícitas, o que acarretara no alargamento das apreensões policiais por uso destas substancias com a inclusão de jovens brancos de classe média no perfil de usuários. Alguns pesquisadores apontam que as práticas contestadoras desta parcela da elite brasileira se tornaram ameaças ao regime, o que os incluiu no rol dos alvos de controle da legislação de drogas, todavia o desdobramento das apreensões deste estrato social se valeu da influencia médica na questão, constituindo a categoria do "infrator doente”, direcionando para o campo da Saúde em lugar do Direito Penal, as responsabilizações advindas de apreensões de 
jovens de classes mais privilegiadas, o que veio restabelecer a dicotomia de classes na atenção pública ao delito ligado às drogas (Delmanto, 2013).

Nas décadas seguintes o país implementa legislações mais duras e alinhadas à Convenção Única sobre Entorpecentes das Nações Unidas de 1961. Dentre estas, destacam-se o Decreto 54.216 de 1964 que reiterava a necessidade de autorização legal para a posse de Cannabis e a Lei 6.368 de 1976 que igualava traficantes e usuários quanto a responsabilização penal (Delmanto, 1982 e Torcato, 2014). No contexto político, o regime de exceção instaurado a partir do golpe militar de 1964 fomentava ações repressivas diante aspectos contraculturais que estavam ligados ao consumo de determinadas substancias psicotrópicas tais como o LSD que recentemente saia do âmbito das universidades estadunidenses e alcançava outras populações (Torcato, 2014; Velho, 1994).

A Lei de Segurança Nacional, ordenamento jurídico que surgiu no período da ditadura militar materializava a "Doutrina de Segurança Nacional”, dispositivo de regulação fortemente influenciado pela proposição norte-americana de combate ao comunismo, a qual elegia como inimigo do Ocidente os países alinhados com a antiga União das Repúblicas Socialistas Soviéticas (URSS), no contexto da chamada Guerra Fria. No discurso das Forças Armadas Brasileiras esta ameaça comunista constituía a razão deste arcabouço legal que concedia aos militares o controle político, econômico e social da Nação todavia, desde o fim do governo de Getúlio Vargas, pesquisadores apontam disputas políticas internas nos oficialatos do exército brasileiro, quanto a uma postura intervencionista militar (Carvalho, 2005; Oliveira, 2010). Ao mesmo tempo, a aproximação de Vargas às demandas de camadas mais populares, provocou reações na burguesia industrial da época, o que isolou politicamente o então Governo, instaurando a sensação social de periculosidade iminente mesmo nos herdeiros políticos de Getúlio (Oliveira, 2010).

Neste sentido, a Doutrina de Segurança Nacional, que mais tarde utilizaria sua estrutura para o combate às drogas e ao tráfico, surge como dispositivo aglutinador de interesses tanto dos setors militares como também de interesses de classes dominantes na manutenção do "status quo" vigente (Oliveira, 2010; Assunção, 1999). 
Com o fim do regime de excessão na década de 1980 a anistia proposta pelo Governo Militar buscou alinhar os clamores sociais pela redemocratização com a manutenção das relações sociais de dominação as quais engendraram seu acesso ao Poder. Mais uma vez as organizações sindicais de esquerda e também os movimentos populares que despontaram no processo de abertura democrática no final do Governo Militar entrariam em choque com o projeto de manutenção das relações sociais de dominação no país. No mesmo período, no contexto mundial a URSS vinha enfraquecendo sua liderança geopolitica e desapareceria ainda na mesma década, representando o fim da ameaça comunista que legitimava o intervencionismo estadunidense por meio do combate aos subversivos na América Latina.

Fora neste panorama sócio-político interno e externo do país que a legislação penal aplicada às substancias ilícitas moldou, no interior do modelo de redemocratização implementado, um novo inimigo interno, um novo adversário a ser combatido se necessário com o uso da força repressora, entretanto agora o sistema de coerção não incluía no bojo de suas ações o jovem subversivo bem estudado de classe média, delimitava suas intervenções aos jovens pobres, de regiões periféricas, sob a justificativa destes se tornarem potenciais soldados a serviço do tráfico de drogas (Torcato, 2014; Carvalho, 2007).

Esta estratégia interna das elites brasileiras vinha de encontro as necessidades imperialistas estadunidenses de controle regional, uma vez que, com o fim da Guerra Fria necessitavam buscar um novo inimigo para legitimar suas ingerências internacionais na América Latina (Delmanto, 2012; Arantes, 2004). Na conjuntura geopolítica mundial esta política proibicionista, encampada pela Organização das Nações Unidas desde a década de 1960 unia interesses econômicos que fizeram do comércio ilícito de substancias normativamente proibidas uma das industrias mais rentáveis do planeta.

O modelo de repressão bélico dos EUA aos narcotraficantes latino americanos buscou consolidar um circuito de controle e vigilância que, no microcosmo da vida privada, pudesse ser replicado para os diversos países sob as quais mantinha influencia hegemônica (Carvalho, 2007; Carneiro, 2003; Rodrigues, 2002). Todavia, inúmeras pesquisas sobre esta relação matricial de combate às drogas apontam que ela forneceu muito mais um espaço político de influencia 
estadunidense do que respostas efetivas no enfrentamento à criminalidade ligada ao tráfico de substancias ilícitas. 


\section{Capítulo 2}

\section{Breve histórico da Justiça Juvenil}

Nos primeiros séculos do período colonial a criança aparece em poucos retratos da vida social, embora possivelmente ja trabalhassem com os pais desde os primeiros anos da infancia e, aos doze, ja alcançavam valor de mercado no contexto escravista da época. Com o acesso à educação limitado, em particular para crianças e jovens pobres, restava-lhes desde muito cedo o trabalho nas lavouras e oficinas, na perspectiva de que através do labor pudesse torná-los pessoas úteis e produtivas (Jimenez \& Frasseto, 2014; Del Priori, 2009).

Fora somente no século XX que infantes e adolescentes ganharam notoriedade nos documentos oficiais, com o surgimento do personagem social dos pivettes (Del Priori, 2009). Como veremos mais adiante, os primeiros registros do envolvimento de crianças em delitos penais datam desta época. No contexto da industrialização das cidades e do crescente numero de crianças vivendo nas ruas, este novo perigo potencial passa a chamar a atenção do Estado fomentando as primeiras estratégias de controle social desta população (Jimenez \& Frasseto, 2014).

Desde meados do século XIX, a questão da criminalidade infanto- juvenil já atravessava discursos e normativas do sistema jurídico brasileiro, o resultado eram práticas institucionais que oscilavam entre uma perspectiva punitiva ou assistencialista nas soluções para o enfrentamento da questão. (Jimenez \& Frasseto, 2014). Costuma-se considerar o ECRIAD um terceiro momento das legislações que versam sobre o direito juvenil, com a primeira etapa tendo início com a Independência e os primeiros Códigos Nacionais direcionados a esta faixa etária no Brasil

O primeiro Código Criminal do Império, promulgado em 1830, inaugura o período conhecido como penal indiferenciado no Sistema de Justiça Juvenil. Neste documento é possível encontrar a primeira menção para a inimputabilidade de crianças e adolescentes com até 14 anos. 
Ainda assim, para aqueles com idade entre 7 e 14 anos, para quem fosse possível comprovar discernimento, a legislação previa uma ressalva para a possibilidade de imputabilidade, outorgando ao juiz a avaliação desta capacidade cognitiva dos infantes. Na prática, as sentenças aplicadas pelos Fóruns criminais daquele período não faziam distinção por faixa etária e reservavam para crianças, adolescentes e adultos as mesmas punições nas casas de Correção do Império, limitando-se a um efeito atenuador no tempo de sanção das penas aplicadas aos menores de 14 anos. (Sposato, 2011; Sartório \& Rosa, 2010; Shecaira, 2008).

Nesta época o processo de desenvolvimento recebia o impulso da vinda de imigrantes europeus para o país e da abolição dos escravos, ao mesmo tempo que via as estatísticas sobre jovens abandonados, em situação de delinquência ou vadiagem nos espaços urbanos dispararem nos registros criminais do período (Delgado, 2013).

Na virada do século XIX para o XX, influenciado pelo modelo norte americano, o direito juvenil adentra a chamada etapa tutelar, assim conhecida por concentrar na figura do juiz a capacidade de decidir, em nome do inimputável, o que seria melhor para seu futuro (Sposato, 2011; Souza, 2013). O documento que inaugura esta etapa é o Código de Menores de 1927, que consolida a nomenclatura menor como categoria de inteligibilidade na justiça brasileira, (Borghi, 2010). Os artigos deste Código reiteravam a legitimidade das práticas discricionárias dos operadores da justiça, o antigarantismo e apontava para a criminalização das questões sociais. É neste etapa que se estabelece a figura do juiz de menores e o entendimento de criança abandonada como sinonimo de criança infratora, a qual alcançará seu ápice com a Doutrina da Situação irregular décadas mais tarde. (Souza, 2013; Sposato, 2011).

Essa relação de complementariedade entre os conceitos de delinquência e abandono foi comum nos Sistemas de Justiça Juvenis dos países latino-americanos no último século. As funções estatais de proteção e controle social conviviam lado a lado com práticas coercitivas e a noção de periculosidade, num mecanismo de regulação que se aplicava especialmente àqueles setores considerados mais vulneráveis da população das cidades. Para a infância, mais especificamente para crianças oriundas de setores sociais mais privilegiados, o controle é 
exercido pela família e pela escola, para os menores: seu controle deve ser exercido pelos tribunais. (Gomes, 2011;Sposati, 2006).

Na década de 1930 o projeto nacional do Estado Social brasileiro de Getúlio Vargas impulsiona as políticas sociais visando à incorporação das massas urbanas. Para crianças e adolescentes toda uma estrutura de assistência e atendimento é então erigida tendo o Serviço de assistência ao menor (SAM) como um de seus principais equipamentos. Com uma orientação correcional repressiva o SAM difunde esta modalidade institucional de atenção a adolescentes e jovens por todo o país. (Batista, 1998).

Com o golpe militar de 1964 o autoritarismo estatal ganha força e se legitima dentro da lógica da Defesa Social, doutrina elaborada pela Escola Superior de Guerra no contexto ideológico internacional da Guerra Fria e que foi de grande valia para o governo militar na escolha dos inimigos internos a serem combatidos. (Batista, 1998). Neste contexto surge a Política Nacional de Bem Estar do Menor, a qual por sua vez origina a Fundação Nacional para o Bem Estar do Menor (FUNABEM) e suas respectivas unidades estaduais, dentre as quais, aquela localizada no Estado de São Paulo, representará o ápice desta lógica e a mais evidente metáfora da repressão à criança e ao adolescente no país (Pereira, 2008). Além de reproduzir a nivel nacional o ideário da segurança nacional, a FUNABEM consolida concepções estigmatizantes e deterministas dos adolescentes pertencentes a camadas mais pobres da sociedade. (Batista, 1998).

A ótica da culpabilização dos jovens e a impossibilidade do convívio em sociedade arrefecem neste período. Novamente o conceito de periculosidade legitima um tipo de fantasia social que valida a gestão social dos riscos através da construção de espaços de exclusão e controle (Rosa \& Vincentim, 2010). No código penal de 1973, ainda que se tenha evoluído na compreensão da questão abandono e delinquencia, os legisladores ainda reservam unicamente aos operadores da justiça o protagonismo nas ações. Ao nível da doutrina, desconsideram a garantia de ampla defesa, ou mesmo de qualquer tipo de defesa: “O jovem em “situação irregular” é processado e entra no circuito penal sem que apareça a figura do advogado. Um dos eixos do processo menorista é o não reconhecimento do menor como pessoa, mas como alguém a ser tutelado”(Batista, 2003, p. 79). 
Foi somente nas últimas décadas do século XX, com o fim da ditadura e o processo de redemocratização do país que as lutas comunitárias e os crescentes movimentos sociais encontraram o terreno político propício para a superação desta doutrina. Inspirada na Convenção dos Direitos da Criança e do Adolescente de 1989 e nas Regras mínimas das Nações Unidas para Administração da Justiça Juvenil , a Constituição Federal de 1988 inaugura um terceiro momento histórico nas legislações postulando o ideal de promoção do "bem de todos, sem preconceitos de origem, raça, sexo, cor, idade e quaisquer outras formas de discriminação” (Brasil, 1990, art. 3º, inciso IV).

A Lei 12.594 - SINASE e o Departamento de Execuções da Infância e Juventude de São Paulo DEIJ-SP 
A década de 1980 se inicia com novas possibilidades de diálogo e interação entre Estado e movimentos populares na cidade de São Paulo no tocante a questões sociais de base, bandeiras históricas do associativismo de bairro, muitos deles ligados à Pastoral da Criança, braço de ação social da Conferencia Nacional dos Bispos do Brasil (CNBB). Criado em 1983 na cidade de Londrina, a Pastoral se dedica inicialmente a combater a mortalidade infantil e a desnutrição, propondo um novo modelo de filantropia a qual propõe o bem comum pela ação voluntária de todos, se posicionando contra a lógica paternalista das doações. (Nascimento, 2006)

Para o campo dos direitos da infância e adolescência algumas pautas engendravam ainda efeitos diretos de práticas repressoras, reforçadas no período de intervenção militar. Fora sob a égide da Doutrina da situação irregular, referendada pelo governo ditatorial, que a resposta Estatal para infrações cometidas por menores de 18 anos ganhou os contornos estruturais que desembocaram nos conflitos ocorridos nas Unidades do Tatuapé e Raposo Tavares. (Vincentim, 2005).

Por características próprias, o movimento popular pela luta dos direitos da infância e adolescência na cidade de São Paulo tem uma histórica tradição de atuação comunitária. Nesta perspectiva a atuação conjunta com o Poder Judiciário representou uma composição que viabilizou conquistas que se refletiram nos ordenamentos nacionais. Juizes e promotores atuaram, ao lado dos movimentos sociais, no fim dos anos 90 e início dos anos 2000, no combate à violações de direitos na antiga Fundação do Bem Estar do Menor - Febem. Muitos casos de tortura foram identificados nesta atuação. (DCI São Paulo, 2005).

O processo de municipalização, reforçado pela Lei 12.594, é um dos exemplos desta forma de organização e militância, remete a importantes transformações sociais no campo das políticas públicas para a infância e juventude. Dizendo respeito em especial, as medidas socioeducativas em meio aberto, sua importância torna-se fundamental para nossa discussão nos anos de 2015 e 2016. Mais uma vez, tratar deste tema a partir dos eventos ocorridos na cidade de São Paulo possibilita um recorte de pesquisa de grande potência, uma vez que a capital paulista, 
por conta de suas peculiaridades demográficas diante outras cidades brasileiras, ditou os rumos das discussões que resultaram nas atuais legislações que tratam do campo socioeducativo.

Neste sentido, o modelo atual de acompanhamento de medidas em meio aberto remonta profundamente a este percurso de lutas, com implicações diretas para a legislação atual e, por consequência, para os operadores do direito que nela atuam. Esta herança histórica refletiu no perfil militante da atuação e da produção bibiográfica. Em menor ou maior grau, o convívio com as torturas e violações imprimiram um tom de denuncia e manifesto em muitos dos estudos da área. 


\section{Objetivos}

Investigar as posições que podem coabitar as práticas da Justiça Juvenil, a fim de atualizar as discussões teóricas entre Doutrina da Situação Irregular e Doutrina da proteção Integral, bem como suas novas configurações no Sistema Socioeducativo. Problematizar as formas de exercício do poder decisório nas audiências de apresentação de adolescentes e jovens envolvidos no varejo do tráfico de drogas na cidade de São Paulo no contexto da lei da Lei 12.594- SINASE

Busca-se atualizar as investigações sobre as práticas de controle social e responsabilização sócio-penal no sistema de justiça juvenil, buscando compreender como têm se superado as históricas práticas de criminalização da pobreza ao mesmo tempo em que se implementam ações de promoção da cidadania, da equidade e do protagonismo juvenil. 


\section{Aspectos metodológicos}

Trata-se de estudo exploratório via análise documental de pastas técnicas, registro do processo judicial aplicado a adolescentes que cometeram ato infracional na cidade de São Paulo no período compreendido entre julho de 2015 e julho de 2016, aos quais receberam medida socioeducativa decorrentes da infração equiparada ao crime de tráfico de drogas. Elegemos este recorte temporal por este coincidir com o período previsto para a primeira avaliação do Plano Nacional de Atendimento Socioeducativo, a qual operacionaliza os preceitos da Lei 12.592/2012.

A pesquisa fora realizada no Departamento de Execuções da Infância e Juventude, localizado na Rua Piratininga, 105, na cidade de São Paulo. Quanto aos tipo de processo indicamos que já foi discutida a natureza da medida socioeducativa de Liberdade Assistida e sua posição estratégica para a avaliação da responsabilização que se tem praticado nas sentenças, bem como quais aspectos pedagógicos, necessários à Integração Social têm sido contemplados pelos tribunais (Gobbo \& Muller, 2011).

Para a análise dos dados, lançamos mão da ferramenta metodológica da Análise de Conteúdo, na perspectiva implementada por Bardin (1970) e Minayo (2007). Segundo SILVA, C. R. et al. (2005, p. 74): “O método da análise de conteúdo aparece como uma ferramenta para a compreensão da construção de significado que os atores sociais exteriorizam no discurso”.

Em outra publicação, Minayo (1992) postula três fases fundamentais para desenvolvimento do método: a pré-análise, a exploração do material e o tratamento dos resultados. Primeiro estabelece-se o esquema de trabalho, com procedimentos bem definidos, embora flexíveis, essa é chamada de pré-análise. A fase seguinte, a exploração do material, aprofunda-se o que fora investigado de maneira preliminar anteriormente. Na última fase, procura-se tornar os resultados brutos significativos e válidos.

Nossa primeira etapa de seleção, a qual corresponde ao nível da pré-análise, teve como crivo as pastas que atendiam aos critérios de período e tipo de infração e deste primeiro movimento de seleção encontramos cerca de 62 processos de adolescentes ou jovens, dentre as 
quais tínhamos a perspectiva de aprofundar oito processos de adolescentes em cumprimento de medida socioeducativa por tráfico de drogas.

A peculiaridade dos dados se deve a questões específicas do campo e das condições de coleta, aqui cabe a ressalva quanto a regras e questões organizacionais do DEIJ no acesso a prontuários no cartório. Dispunhamos de tempo restrito para contato com os dados, cerca de duas horas diárias as segundas e quartas feiras, conforme autorização da Juiza responsável pelo Departamento de Execuções. Neste contexto de pesquisa a disposição das pastas técnicas, a qual compunha meu universo de consulta, seguiam uma cronologia específica, que em geral se orientava numa ordem temporal decrescente. Assim, um dos critérios para seleção das pastas a serem analisadas em profundidade, dentre estes 62 processos encontrados, seriam aqueles com menor tempo de ocorrência, mas este filtro não pode ser integralmente aplicado pela dinâmica de funcionamento do Cartório do Departamento de Execuções. Algumas pastas poderiam ser retiradas do cartório para consulta de uma semana para outra, por conta dos pedidos de vistas, o que se referem ao procedimento de análise que os operadores do sistema de Justiça têm a seu dispor ao curso do processo judicial.

Sendo assim, destas 62 pastas iniciais restaram doze processos aos quais puderam ser analisados em profundidade, referentes a adolescentes ou jovens que se enquadravam nos critérios iniciais de seleção. Estes foram transcritos a fim de se transformarem em dados qualitativos para nossa pesquisa. As transcrições buscaram estabelecer padrões nas seções redigidas, entretanto, como já apontado, a dinâmica de acesso a documentos jurídicos obedece à rotatividade processual, o que resultou no conteúdo das transcrições; algumas seções apresentam mais informações do que outras, algumas contém seções que não encontramos em outros processos. Todavia, o instrumento da análise documental das pastas possibilitou extrair dos registros de processos campos de problematização entre condutas tipicamente menoristas e aquelas fundamentalmente ligadas à proteção integral, mas fundamentalmente, algumas posições entre estes pólos. Um conjunto de informações a priori sem significado por si só, mas que, interpretados no contexto de análise produziram um conhecimento válido sobre nossa questão. (Costa, 2015). 
Acerca das seções redigidas, apresentamos uma breve descrição acerca da composição específica delas e sua função no processo:

A primeira peça que utilizamos em nossa análise é, em geral, aquela que inicia as pastas socioeducativas: a Representação do Ministério Público, peça que retoma a indicação do boletim de ocorrência policial mas que tem por função primordial transcrever a denúncia ofertada pelo Promotor público, operador do direito que recebe o desígnio de realizar a oitiva informal do adolescente ou jovem decidindo pela abertura de um processo socioeducativo ou por sua remissão; esta seção esta presente em oito dos doze processos analisados.

A seção seguinte se refere à audiência de apresentação, primeiro movimento na qual diversos atores do processo socioeducativo deliberam diante a denuncia apresentada pelo promotor na peça de representação, a saber o promotor público, o defensor público ou advogado de defesa do adolescente ou jovem e o juiz da infância e adolescência. Em alguns casos, esta audiência ocorre logo após a apresentação do adolescente no Departamento de Execuções, em outros, alguns dias separam a denúncia do promotor deste primeiro encontro com o Juiz que preside a referida audiência; esta seção esta presente em oito dos doze processos analisados.

Em um dos processos analisados, estava presente uma seção a qual não fora encontrada em outros processos mas que antecede formalmente a audiência de apresentação apresentada no parágrafo anterior. Trata-se do despacho de Decisão, que consiste na demonstração do aceite por parte do Juiz da Vara de apuração acerca da denúncia oferecida pelo Promotor Público. Este rito formal não é seguido por todos os magistrados que atuam no Departamento de Execuções, o que revela sua ocorrência em apenas um dos doze processos analisados.

A próxima seção transcrita é a que traz o relato transcrito da audiência de continuação; rito processual que encerra a fase inicial de apuração das medidas socioeducativas e que, em geral, já é designada na audiência de apresentação. Nesta audiência, os mesmos atores da audiência de apresentação formalizam a imposição da sanção a ser cumprida pelo adolescente em tela. Esta seção esta presente em quatro dos doze processos analisados. 
Também foram transcritos dados de Relatórios Polidimensionais da Fundação CASA, que acompanha os adolescentes nas medidas de internação e relatórios técnicos da equipe técnica que acompanha as medidas em meio aberto. Estes relatos são construídos ao longo das apreensões iniciais que antecedem as audiências de apresentação ou de continuação, período em que os adolescentes ou jovens permanecem internos nas unidades de internação provisória antes da sanção definitiva, assim estes relatórios tem a peculiaridade de realizar um diagnóstico multidisciplinar do reeducando num curto espaço de tempo, diagnóstico este que poderá servir para embasar a definição das sanções nas audiências de continuação ou conclusão. Estes relatos estão presentes em dez dos doze processos analisados.

Por fim, alguns dos processos traziam informações de sanções cumpridas em meio aberto, trata-se do Plano Individual de Atendimento ou de Relatórios de Acompanhamento de medidas socioeducativas; Seja por infrações anteriores, as quais os adolescentes foram acompanhados por um serviço de medida socioeducativa em seu território. Optamos por incluir estas informações por apresentarem conclusões relevantes para a analise dos processos aos quais estavam presentes, agregando novas dimensões de compreensão do recorte de realidade apresentada na pasta técnica. Este recorte esta presente em cinco dos doze processos analisados.

Depois teremos o recorte dos conteúdos, definição das categorias analíticas, a categorização final das unidades de análise a fim de que estas forneçam subsídios para a discussão das hipóteses nas seções de resultados e conclusão.

Indicamos que esta divisão seguia uma ordem cronológica dos autos e após o trabalho de campo, promovemos uma sistematização dos dados e procedemos por derivação empírica e teórica novas categorias de análise dos dados que resultaram em categorias construídas na articulação com a produção acadêmica sobre a temática da infância e adolescência. Destacamos que o arcabouço teórico explicitado funciona como base na qual os conteúdos de campo aportaram sentido, numa relação dialética de ressignificação daquele momento, naquela situação em particular, tal como as ferramentas de análise qualitativa permitem: 
Mas também é preciso saber que a experiência e a vivência de uma pessoa ocorrem no âmbito da história coletiva e são contextualizadas pela cultura do grupo em que as insere. Toda compreensão é parcial e inacabada, tanto a do nosso entrevistado, que tem um entendimento contingente e incompleto de sua vida e de seu mundo, como a dos pesquisadores, pois também somos limitados no que compreendemos e interpretamos (Minayo, 2012, p. 623).

Entendendo sua dinâmica constitutiva como território de embate micropolítico marcado por relações de poder, propusemos uma sistematização analítica das concepções e dos argumentos, e sua possibilidade de revelar jogos de subjetivação e objetivação que legitimam, em diferentes dimensões, um processo de exclusão e encarceramento dos indesejáveis (Foucault, 2012).

A investigação da lógica interna das relações entre sistema de justiça juvenil e narcotráfico possibilitou dimensionar o peso real das injunções que recaem institucionalmente sobre adolescentes que se encontram em conflito com a Lei (Pereira, 2012) bem como, a compreensão, ainda que parcial do Sistema Socioeducativo, naquilo que se refere a seus modelos de concepção sobre o ato de mediar conflitos por meio do devido processo legal (Brasil, 1990). Sob nossa perspectiva, esta morfologia da justaposição de Doutrinas e posições se materializa nas narrativas de alguns de seus operadores, bem como as representações e o significado que suas práticas adquirem no contexto de sua atuação, estas passíveis de serem vistas apenas pelo vértice da contradição entre a doutrina que queremos e aquela que temos (Frasseto, 2006).

Ressaltamos que a análise na perspectiva que adotamos não se propõe a descobrir uma nova verdade ou dizer o correto a se fazer nas condutas analisadas, mas sim propor uma nova interpretação ou mesmo apontar aspectos outros do fenomeno.

Na situação de audiencia histórias de vidas diversas se relacionam por meio da linguagem e neste entrecruzamento travam batalhas nas frias salas de audiências (Scisleski \& Guareschi, 2011). A análise das etapas do processo, desde a oitiva dos promotores, ao qual procedem a denúncia da conduta típica através da representação formal, tendo como base o boletim de ocorrência, que traz a verdade dos fatos segundo a jurisidição policial do território que emitiu o documento; a escrita dos defensores, no cumprimento do papel regimental do contraditório e da 
defesa dos adolescentes acusados bem como a sentença dos juízes, aos quais decidem a partir da lei, mas o resultado varia em função de seu alinhamento a determinada Doutrina que intentamos mapear.

Cumpre salientar que este estudo tomara todos os cuidados éticos cabíveis, submetendo o projeto de pesquisa para consentimento de todas as Instituições envolvidas, tais como o Departamento de Execuções da Infância e da Juventude da cidade de São Paulo e o Comite de Ética em Pesquisa do Instituto de Psicologia da Universidade de São Paulo.

Desde o recebimento da autorização do Departamento de Execuções do Brás, realizamos oito incursões ao cartório e tivemos acesso, inicialmente a 62 processos, aos quais numa escolha até certo ponto aleatória, uma vez que conforme orientação dos funcionários do cartório, a cada dia de pesquisa selecionávamos 6 processos dentre aqueles que se encontram nos prazos mais recentes de execução. Destes conseguimos analisar com profundidade doze processos, uma vez que a referida consulta têm uma limitação temporal diária de duas horas.

Como já apontado, as pastas técnicas estudadas apresentavam uma substancial variação de conteúdo, todavia não nos cabe tecer conclusões sobre a composição e organização do material uma vez que, não possuímos conhecimento jurídico para tal questão e também, no período em que estivemos no campo, foi possível observar a dinâmica existente ao longo dos ritos processuais a qual envolve diversas instancias, Ministério Público, Defensoria, Varas de Apuração e Execução, Fundação CASA e Serviços de Medidas em meio aberto, cada qual com funcionamento e rotinas próprias, o que resulta numa composição aproximada das pastas técnicas.

No que se refere as posições do Ministério Público, apenas no primeiro relato, pela limitação dos dados, não é possível concluir quanto a posição tomada pelo representante da Promotoria Pública. Em todos os processos seguintes o Promotor (a) conclui pela ocorrência do tráfico de drogas, oferecendo a denúncia e requerendo a Internação provisória do adolescente ou jovem envolvido na ação. 
Nas audiências de decisão, apenas na primeira transcrição encontramos uma sentença que acolhe a sanção de Liberdade Assistida como resposta ao delito equiparado a tráfico de entorpecentes, todavia como já ressaltamos, comparativamente este relato é aquele que possui menos dados transcritos destas seções. Assim, exceto no $3^{\circ}$ relato a qual não apresenta esta seção Decisão e no $6^{\circ}$ relato a qual o magistrado acolhe parcialmente a denúncia da Promotoria indicando a internação por um período menor que o proposto pelo Promotor, em todos os outros processos a decisão do Juiz acolhe o requerido pelo Ministério Público.

Quanto as situações de apreensão dos adolescentes, em sete dos nove processos analisados, esta fora realizada por policiais militares, sendo que, apenas na $2^{\circ}$ e $8^{\circ}$ transcrição esta abordagem fora realizada por policiais civis.

Por fim, quanto aos relatórios realizados pelas instituições responsáveis pelas sanções, apenas o primeiro relato não possui o Relatório Polidimensional construído pelo corpo técnico da Fundação CASA, a qual elabora uma primeira avaliação logo da chegada do adolescente a um Centro de Acolhimento Provisório. Este documento informativo do adolescente se subdivide em pareceres por áreas psicológica, social, pedagógica, de saúde e segurança. Nos processos analisados, esta primeira avaliação era redigida por um ou dois técnicos, em geral, profissionais da Psicologia ou da Assistência Social. Todos os outros processos analisados, possuem trechos deste documento diagnóstico. Esta seção, possui dados importantes para nossa análise, todavia optamos por construir nossas categorias a partir das seções anteriores, uma vez que estes relatos são os que menos apresentavam uma uniformidade de dados.

Após uma decisão do Juiz da Vara de Apuração por sanção de privação de liberdade, a qual pode se estender por um período de até 45 dias, conforme determina o ECA, os técnicos da Unidade de Internação redigem um novo relatório a qual apresentam os resultados das intervenções no período e as metas a serem trabalhadas. Este documento, desde a Lei 12.594, de 212, a qual instituiu o SINASE, propõe um modelo de Plano Individual de Atendimento para cada adolescente ou jovem, propondo uma análise mais global e singular de cada atendido por esta politica pública. Apresento a seguir uma tabela da organização do material de campo. 
Tabela

\begin{tabular}{|c|c|c|c|c|c|c|}
\hline & Representação & $\begin{array}{c}\text { Relatório } \\
\text { SME - } \\
\text { MA }\end{array}$ & $\begin{array}{l}\text { Audiência de } \\
\text { Apresentação }\end{array}$ & $\begin{array}{c}\text { Audiência } \\
\text { de } \\
\text { Continuação }\end{array}$ & Decisão & $\begin{array}{c}\text { Relatório } \\
\text { Fundação } \\
\text { CASA }\end{array}$ \\
\hline João I & $\mathbf{X}$ & $\mathbf{X}$ & & & & \\
\hline João II & & & $\mathbf{X}$ & & & $\mathbf{X}$ \\
\hline João III & & & $\mathbf{X}$ & & & $\mathbf{X}$ \\
\hline João IV & $\mathbf{X}$ & & $\mathbf{X}$ & & & $\mathbf{X}$ \\
\hline João V & $\mathbf{X}$ & $\mathbf{X}$ & $\mathbf{X}$ & & & $\mathbf{X}$ \\
\hline João VI & & & $\mathbf{X}$ & & & $\mathbf{X}$ \\
\hline $\begin{array}{l}\text { João } \\
\text { VII }\end{array}$ & $\mathbf{X}$ & & & $\mathbf{X}$ & & $\mathbf{X}$ \\
\hline $\begin{array}{l}\text { João } \\
\text { VIII }\end{array}$ & & $\mathbf{X}$ & & $\mathbf{X}$ & & \\
\hline João IX & $\mathbf{X}$ & & $\mathbf{X}$ & $\mathbf{X}$ & & $\mathbf{X}$ \\
\hline João X & $\mathbf{X}$ & & $\mathbf{X}$ & & $\mathbf{X}$ & $\mathbf{X}$ \\
\hline João XI & $\mathbf{X}$ & & & $\mathbf{X}$ & & $\mathbf{X}$ \\
\hline $\begin{array}{l}\text { João } \\
\text { XII }\end{array}$ & $\mathbf{X}$ & $\mathbf{X}$ & $\mathbf{X}$ & & & $\mathbf{X}$ \\
\hline
\end{tabular}




\section{Como a banda toca: Análise e discussão dos dados}

Após apresentarmos uma descrição de nossos dados prosseguimos nas próximas seções uma análise sobre os dados latentes de nosso material, com a perspectiva da construção de categorias embasadas na teoria e no desenvolvimento dos dados de campo.

No que se refere às práticas de ingresso no sistema socioeducativo, nos referimos aos procedimentos de apreensão e abordagem de adolescentes e jovens, quando do cometimento de um ato infracional. Os dados desta categoria são provenientes dos Boletins de Ocorrencia policial aos quais se localizam no início das pastas técnicas e são peça fundamental para o trabalho seguinte realizado pelo Ministério Público, bem como para os outros atores da Justiça Juvenil

Em nossa coleta de campo, tivemos acesso a cópia dos Boletins que integram a pasta técnica de processos socioeducativos, entretanto, optamos por transcrever apenas as peças de Representação, uma vez que estas retomam grande parte do conteúdo do Boletim de Ocorrência, muitas de forma literal, e indicam quais recortes do referido Boletim serão apreciados nas diferentes etapas dos processos da Justiça Juvenil.

O Boletim de Ocorrência é o documento que formaliza a tomada de conhecimento sobre um delito por parte das autoridades competentes, sua lavratura é de responsabilidade do Delegado titular, ou Escrivão sob sua supervisão, e suas informações embasarão a instauração de um processo socioeducativo após apresentação do adolescente ou jovem à Seccional Policial que abrange a região a qual ocorreram os fatos delituosos. A estrutura deste Boletim consiste na transcrição literal de uma narrativa acerca uma conduta típica, ou seja, ação prevista como ilícita pelo Código Penal vigente. O referido documento representa o ingresso no processo ressocializador, conforme preconiza o Estatuto da Criança e do Adolescente (Brasil, 1990) e suas informações serão reiteradas ao longo das etapas subsequentes do processo. Como apontado, todas as informações relativas ao ato infracional devem constar nesta transcrição, uma vez que ele constitui peça fundamental nos ritos processuais, conforme preconiza a mesma legislação penal supra citada (Mirabete,2001; Pereira, 2008). 
Em geral, os relatos extraídos dos Boletins aos quais tivemos acesso se iniciam com expressões como apurou-se ou foram informados, conforme pudemos observar em trechos de nossas transcrições:

Apurou-se que o representado foi abordado por policiais militares no local ... (João IV)

Segundo se apurou, policiais militares foram informados de que no local dos fatos estaria ocorrendo o tráfico de entorpecentes assim, para lá se dirigiram. Chegando ao lugar supramencionado, avistaram o adolescente em atitude suspeita e resolveram abordá-lo... (João IV)

Apurou-se que os adolescentes encontravam-se na via pública, quando foram abordados por policiais. ( João V )

Segundo se apurou, policiais militares em patrulhamento pelo local dos fatos, avistaram três indivíduos em atitude suspeita, posteriormente identificados como os adolescentes acima citados e o imputável Abraão IX. (João VIII)

Destacamos estas sentenças, as quais abrem os documentos responsáveis por informar a infração às autoridades competentes, num primeiro momento por sua recorrência, tal como nos aponta nossa metodologia de análise dos dados (Minayo, 1997). Entretanto, o tema da busca pessoal e seu exercício por parte de agentes estatais possui uma vasta produção científica não só no campo da Adolescência em Conflito com a Lei, mas também em toda prática forense no Instituto do Direito Penal. A esse respeito, Galduróz (2014) discute a existência de uma discussão mais consistente, no âmbito da Acadêmia e da prática forense, sobre os limites do Estado no Instituto da busca domiciliar, a qual não encontra paralelo quando o alvo da intervenção passa a ser a intimidade, o corpo, ainda que ambos se inscrevam na mesma categoria dos Direitos Fundamentais. Ainda que os requisitos que ensejam a adoção desta medida, potencialmente violadora de direitos, estejam apontados nos artigos 240 e 244 do Código de Processo Penal a fim de preservar a prerrogativa do princípio da dignidade humana bem como para exercer papel de garantia diante possíveis ações arbitrárias do Poder Estatal, sua adoção indiscriminada ultrapassa 
os limites da Justiça Juvenil e se estende á todos aqueles elegidos pela seletividade penal para suas ações punitivas (Sanchez, 2016; Teixeira, 2015).

Nesse sentido, podemos dizer que a "atitude suspeita”de nossos sujeitos de pesquisa antecede a apuração das informações, uma vez que, em dois dos enxertos trazidos revela-se muito das teias de exclusão cotidina que estes adolescentes são inscritos, a saber, no direito à cidade e na imbricação territorial das ações do tráfico com as periferias das cidades, onde residem a grande massa atendida pela política socioeducativa. Na atuação profissional com adolescentes em cumprimento de medida, a realidade do dado estatístico confirmava os limites impostos pela ausência de direito. No cotidiano da baixa escolarização que compõe o perfil do adolescente atendido pela medida, era comum encontrarmos meninos de 14, 15 ou 16 anos, alguns no segundo ciclo do Ensino Fundamental ou mesmo no Ensino Médio, com precária capacidade de leitura a qual lhes impossibilitava até mesmo de compreender as placas de Logradouros ou os destinos nos letreiros do transporte público. Para esses jovens, seu bairro, sua vila, são seu espaço público. Ao mesmo tempo, este seu espaço público é campo fértil para uma indústria que se alimenta da desassistência estatal e da vulnerabilidade histórica instalada nas periferias.

Entretanto, a peculiaridade de nosso recorte também lança mão sobre outra questão recorrente na literatura, a qual incide sobre o papel das Corporações integrantes das forças de Segurança Pública no estado de São Paulo. Segundo definição encontrada no sítio da Polícia Militar do Estado de São Paulo na internet (SSP, 2018), as atribuições do policiamento militarizado consistem em patrulhamento ostensivo e preventivo, a qual envolve ações de prevenção em níveis primário e secundário, e cita como exemplos destas ações o policiamento comunitário e o radiopatrulhamento no cumprimento de sua tarefa junto a pasta da segurança Pública (SSP, 2018). Por sua vez a Polícia Civil do Estado de São Paulo é descrita no mesmo sítio como responsável pela investigação de crimes e sua autoria, além da elaboração de Boletins de Ocorencia de qualquer natureza e da expedição de documentos de identificação e atestados de histórico criminal dentre outros (SSP, 2018).

Nesta categoria, nossa amostra revelou uma predominância da ação da polícia militar nas abordagens de adolescentes ou jovens, ocorreu em sete dos nove processos analisados, nos outros 
dois casos estudados, esta apreensão fora realizada pela Polícia Civil. Em um dos processos analisados, a qual não fora incorporado aos nove analisados mais detidamente na presente tese, existe ainda uma menção à investigação realizada pelo serviço reservado da própria corporação militar, a qual tem por função mais específica atuação junto à Corregedoria da Instituição que investiga infrações ou delitos de membros da corporação.

Diante nossos dados, o caráter ostensivo das ações realizadas pela instância militarizada da Segurança Pública restou comprovado nos boletins de ocorrência anexos as pastas técnicas dos adolescentes, ao mesmo tempo, não encontramos informações referentes a uma atuação que pudesse indicar uma prevenção primária, todavia, também não foi possível localizar nas informações institucionais da Policia Militar ao que se referem quando conceituam ações de prevenção primária.

Nos processos de números 1 e 4, existem menções à origem das informações que colaboraram para a prática policial, o que poderia indicar uma atuação próxima daquela descrita nas atribuições da Corporação, ou mesmo a inserção comunitária da atuação policial, todavia, a ausência de clareza das informações prestadas nos boletins não confirma esta hipótese:

Segundo se apurou, os policiais militares foram informados por populares da ocorrência de traficância na região do fato... (João I).

Segundo se apurou, policiais militares foram informados de que no local dos fatos estaria ocorrendo o tráfico de entorpecentes assim, para lá se dirigiram (João V).

No processo de número 3, o Boletim de Ocorrência indica que o adolescente: “foi abordado por policiais militares no local, conhecido ponto de venda de drogas ... (João IV).

A temática da arbitrariedade das prisões por tráfico, ou relacionadas a política de drogas, têm sido um tema problematizado com excelência por muitos pesquisadores (Rocha, 2012; Alvarez, Fraga \& Campos, 2017; Teixeira, 2015; Jesus, 2016). Na esteira de outros trabalhos que já algum tempo discutem as implicações do proibicionismo e dao fracasso do modelo bélico de 
guerra ás drogas, estas discussões desvelam desdobramentos dos dispositivos jurídico-normativos que, sob a alcunha do novo, reatualizam a seletividade do Poder punitivo nas práticas contra determinada parcela populacional (Fiore, 2017; Rodrigues 2002).

Em nosso recorte específico encontramos a reedição deste instituto da discricionariedade policial nas apreensões de adolescentes quando a estes são atribuídos atos infracionais relacionados à questão das drogas (Boiteaux, 2006; Jesus, 2016). Em alguns relatos, os adolescentes ou jovens alegaram versão diversa daquela apresentada pelos policiais que realizaram sua apreensão quando da confecção do Boletim de Ocorrência, em outro, a qual nomemamos ficticiamente de João $\mathrm{V}$, além da prova testemunhal, a conduta anterior dos agentes que realizaram a apreensão fora questionado não só pelo adolescente como também por um de seus responsáveis. Procedimentos investigativos anteriores não foram relatados em oito dos nove processos analisados, a exceção se refere ao processo na qual existe a menção ao Serviço Reservado da Polícia Militar no auxilio àinvestigação. Em todos os outros processos analisados, as testemunhas foram os próprios policiais, civis ou militares, que realizaram a apreensão dos adolescentes ou jovens.

Apresentamos a seguir um recorte de audiência de Apresentação de um adolescente a qual questiona a versão apresentada no Boletim de Ocorrência:

(...)Na audiência de apresentação, o jovem negou a prática do ato infracional. Ele e sua genitora adizirão que a apreensão fora efetuada com outro jovem que estava no mesmo local dos fatos e o policial Zaqueu $V$ pediu dinheiro a ele para libera-lo. Em seguida, atribuiu a falsa acusação ao declarante. (...) A versão apresentada (pelo adolescente) é inverossímil, restou divorciada dos demais elementos coligidos e não merece ser acolhida.

A testemunha Davi V (policial militar que junto com Zaqueu V apreendeu o adolescente) afirmou conhecer o adolescente da ocorrência, até porque nenhum interesse (os policiais) teriam de acusá-lo injustamente (...) (João V) 
Neste relato da posição do Juiz da Vara de Apuração a qual, não só dá prosseguimento à denúncia do Promotor que houvera recebido João V, como também aponta a justificativa em que se baseia para rechaçar a declaração do adolescente e de seu familiar, numa credulidade inquestionável quanto a atuação dos Milicianos. Em seu trabalho de Doutoramento, sobre a construção da Verdade Jurídica nos processos criminais por tráfico de drogas (2016), Maria Gorete de Jesus analisou processos e assitiu audiências no âmbito da justiça e apontou uma aceitação, quase uníssona, da parte de Promotores e Juízes acerca testemunhos ou depoimentos de Policiais Militares, na situação específica de delitos que envolvam tráfico de substancias entorpecentes ilícitas. Tal aceite se encaixa no conceito de crenças, que se "constitui como um ato de fé” (190), um tipo de ideia ou explicação que não necessita verificação ou outro conhecimento para sua validação. Para a referida autora, estas crenças se enquadram em categorias tais como a fé na “função policial”, que dentre outras motivações que envolvem esta a percepção de que os Policiais “atuam em defesa da Sociedade” (p.193-194).

Além desta existem ainda as crenças no “saber policial” e em sua conduta, as quais estão mais próximas de nosso dado de campo, em especial esta última, pois a fala do Magistrado na audiência de apresentação se encaixaria muito bem no quadro explicativo criado por Jesus (p.193, 2016). O quadro elaborado na pesquisa supracitada ainda apresenta mais duas categorias que voltaremos a abordar quando discutirmos os conteúdos das audiências de apresentação, dada a sua aplicabilidade naquela categoria. Entretanto, ao desvelar esta gama de motivações alheias ao curso do devido processo legal a autora lança luz sobre um "regime de validação” (p.196) extra normativo que existe nas práticas forenses, a qual compõem a engrenagem da atuação punitiva do Direito Penal que se reflete na Justiça Juvenil. Ainda que consideremos as limitações de nossa amostra, a literatura reflete esta associação entre práticas da Justiça Comum e práticas da Justiça no campo da Infância e Adolescência.

Em qualquer faixa etária, o desrespeito a garantias constitucionais representa uma violência que deve ser prontamente denúnciada, mas considerando o percurso percorrido pelas legislações da Infância e Adolescência e as disputas para efetivação de uma Política de Proteção Integral, a qual muitos atores do Sistema de Justiça, alguns atuando neste mesmo prédio em que coletamos estes dados, com certeza estas questões representam um conflito que necessita ser 
enfrentado entre a justiça que temos e a justiça que queremos. A aproximação entre operadores da Justiça juvenil e a Sociedade pressupõe uma postura de defesa das garantias fundamentais do estatuto contra intervenções Estatais que negam acesso à direitos, neste caso na manutenção de uma política de Segurança Pública que viola cotidianamente direitos nas periferias. (Jimenez \& Frasseto, 2015; Sierra, 2017). Por agora encerramos esta discussão mas retomamos a ela quando da análise do conteúdo das audiências de Decisão e Apresentação, uma vez que cabe ao Ministério Público e demais atores do Sistema de Justiça Juvenil a fiscalização e eventual apuração de irregularidad Não obstante a lei 8.069 garantir desde a década de 1990 o devido processso legal a todo inimputável a quem se atribua uma conduta infracional e nossa pesquisa já se situar num campo normativo regido por legislações ainda mais recentes tal qual a Lei 12.594 que instituiu o SINASE, a próxima análise a qual intentamos empreender relativa ao conteúdo que encontramos em campo se refere a uma questão institucional que consideramos tão fundamental quanto as demais ora apresentadas nesta sentença.

Isto posto, complementamos as informações que iniciamos a alguns parágrafos atrás, quando tratamos da atribuição de competências entre as Corporações de Segurança do Estado de São Paulo. Se antes, discorremos sobre o policiamento militarizado e suas atribuições, com destque para seu viés ostensivo de atuação, agora apresentamos recortes de nossas transcrições nas quais a apreensão fora realizada por policiais civis, a qual são descritos Institucionalmente em suas atribuições como responsáveis pela investigação e definição da autoria de condutas delituosas (SSP, 2018), encontramos os seguintes relatos:

João II, foi apreendido por policiais civis que avistaram um indivíduo em atitude suspeita, quando realizavam patrulhamento pelo local dos fatos... (João II)

Apurou-se que policiais civis, em diligência pelo local dos fatos, avistaram o adolescente Judas VIII praticando atos típicos do tráfico de drogas. As circunstâncias da apreensão, a quantidade, a forma de acondicionamento, além da confissão do adolescente, evidenciam a prática do tráfico ... (João VIII).

Nas duas abordagens não é possível perceber a diversidade de atribuições ou mesmo, uma relação de complementariedade entre as duas corporações que, junto com a Polícia científica, 
compõem o tripé da Segurança Pública no estado de São Paulo (SSP, 2018). Na amostra estudada, as duas corporações realizam práticas de policiamento ostensivo e de investigação dos atos infracionais conforme depreende-se dos trechos citados. Considerando a articulação proposta pela pasta da Segurança Pública, de maneira a propor uma política de segurança Pública Integrada nas ações contra a criminalidade, no caso especifico a organização criminosa que controla o tráfico de drogas, esta não se revelou na amostra analisada, no período de tempo recortado.

Prosseguindo nossa análise, apresentamos nossa segunda categoria, a qual se detém sobre os conteúdos apresentados nos documentos emitidos por Promotores do Departamento de Execuções da Infância e Juventude, a qual na terminologia judicial recebe o nome de Representação e que tem, dentre outras funções, estabelecer o caminho do adolescente na Justiça Juvenil. Marcado por uma tradicional atuação no campo da persecução criminal no Brasil, o Ministério Público veio redefinindo seu campo desde meados da década de 1930, quando outras atribuições foram incorporadas a suas funções, mas fora somente com a Constituição Federal de 1988 que, institucionalmente, sua função fora redefinida concedendo lhe o status de "representante da sociedade, inclusive em conflitos e na fiscalização de instituições estatais e defensor de interesses difusos e coletivos” (Pereira, 28, p. 748).

Mas fora somente na Lei 8.069 de 1990 que sua jurisdição se ampliou de modo que nenhum dos ritos ou estapas processuais nas varas da Infancia podem ocorrer sem sua manifestação ou ciência a fim de que cumpra sua função constitucional de garantia das prerrogativas do Estatuto (Pereira, 2008). O artigo 201, da referida legislação, trata das competências do Ministério Público, transcrevemos abaixo os dois primeiros incisos:

I - conceder a remissão como forma de exclusão do processo;

II - promover e acompanhar os procedimentos relativos às infrações atribuídas a adolescentes (Brasil, 1990).

Ainda na lei 8. 069, no Capítulo V que trata da remissão podemos encontrar: 
Art. 126. Antes de iniciado o procedimento judicial para apuração de ato infracional , o representante do Ministério Público poderá conceder a , como forma de exclusão do processo, atendendo ás circunstâncias e consequências do fato, ao contexto social, bem como à personalidade do adolescente e sua maior ou menor participação no ato infracional.

No que se refere ao acompanhamento previsto nas atribuições do Promotor, a oitiva informal consiste na primeira intervenção realizada pelo representante do Ministério Público, imediatamente da apresentação do adolescente à Vara de Execução responsável por sua jurisdição. Nesta tomada de informação será determinada pela hipótese da remissão ou da oferta da representação contra o adolescente, verificada a autoria de ato infracional nos moldes da Lei 8. 069.

Estruturalmente, as peças de Representação oferecidas pelo Ministério Público, conforme encontramos em nosso recorte de pesquisa, se inciam com uma releitura do auto de apreensão ou do Boletim de Ocorrência policial circunstanciado. Após este, segue-se uma tipificação do correlato criminal a qual se relaciona a infração que se atribui ao adolescente em tela, acompanhada do rol argumentativo que aponta os indícios de autoria e materialidade que ensejam a definição da autoria (Brasil, 1990). Prossegue com dados da oitiva do adolescente e-ou de seus responsáveis, bem como suas alegações sobre o fato a ele imputado e por fim, o representante do Ministério Público indica sua conclusão solicitando uma das sanções previstas no Estatuto, o que, por sua vez, definirá os passos seguintes do processo socioeducativo, de acordo com o disposto no artigo 122 do ECA. Em alguns casos, acompanha esta decisão, uma retomada do percurso anterior do adolescente na justiça juvenil, se reincidente ou não, bem como aspectos de sua convivência familiar e comunitária, sua vida escolar e questões de saúde. Estas informações são retomadas na linha de uma justificativa que corrobora a decisão final do Promotor. Em algumas das peças de Representação analisada, estas últimas informações são destacadas em negrito, em outras a narrativa se encerra com a requisição da promotoria para o prosseguimento do processo ressocializador. 
Em geral, o relato das peças de Representação analisadas seguiam um padrão textual sem grandes variações em seu vocabulário, com determinadas expressões jurídicas que se repetiram em todos os nove processos analisados. Em específico de nosso recorte de pesquisa, após a apresentação do local dos fatos e da identificação do adolescente ou jovem a qual se atribui a conduta, é retomada a definição do artigo penal que descreve a conduta tipificada como Tráfico de drogas:

Consta do incluso expediente que, nesta cidade e comarca, o adolescente João I, trazia consigo e mantinha em depósito, para entrega de qualquer forma, a consumo de terceiros, substâncias entorpecentes e causadoras de dependência física e psíquica, agindo assim sem autorização e em desacordo com determinação legal ou regulamentar (...) (João I)

... trazia consigo, para consumo de terceiros, substancias entorpecentes causadoras de dependência psico e físico-química, sem autorização e em desacordo com determinação legal e regulamentar, conforme auto de constatação em anexo, e laudo químico-toxicológico a ser oportunamente juntado nos autos... (João IV).

De nossos nove processos analisados, apenas um dos relatos, o de número 2, não apresenta a transcrição parcial ou total da Representação ofertada pelo Ministério Público. Todavia, como já indicado, esta peça processual é retomada ao longo das audiências de Decisão e Apresentação, em menor ou maior grau, na totalidade dos processos estudados. No processo de número 1, o documento emitido pelo Ministério Público fora transcrito parcialmente, sem o parágrafo que aponta a conclusão do Promotor e sua indicação para a continuidade do processo, entretanto, traz a posição do Promotor quanto a definição do ato infracional a partir das informações do Boletim e da Oitiva:

O adolescente em tela trazia consigo para fins de tráfico, 71 invólucros contendo cocaína, conforme laudo de constatação incluso... Ouvidos nos termos do Artigo 179 do ECA, ambos confessaram a traficância (João I). 
Deste modo, exceto a transcrição de numero 1, em todos os outros 8 processos analisados o desfecho da peça de Representação fora o mesmo, com a decretação da internação provisória dos adolescentes ouvidos pelos promotores. Cumpre informar que todas estas solicitações vinham embasadas pela indicação do seu respectivo artigo do Estatuto da Criança e do Adolescente, com a precisão do parágrafo e inciso a qual referendava sua posição, a saber: Assim, com fundamento nos artigos 180, inciso III e, artigo 201 inciso II, ambos da Lei 8069/90 (João VIII). Todavia, ainda que não compartilhemos da posição que situa saberes em disciplinas e ciências estanques tal qual estes fossem uma propriedade passível de posse, optamos por não aprofundarmos no conteúdo do referido artigo, bem como em suas possibilidades interpretativas no exercício do direito, para tal intento indicamos (citação).

Nos interessa, no presente estudo, precisamente aquilo que escapa ao uso da letra da Lei, deste modo discutiremos a seguir outro trecho que comumente acompanhava este requerimento de privação de liberdade provisória designada nos processos analisados:

Destarte, é preciso requerer a decretação da internação provisória dos adolescentes. Trata-se de fato grave, praticado em circunstâncias que denotam a impossibilidade, por ora, dos menores permanecerem no convívio social.

Frisa-se que o adolescente conta com passagem pela $4^{o}$ VEIJ por posse de drogas. ... (João III)

... Destarte, é preciso requerer a decretação da Internação provisória dos adolescentes. Trata-se de fato grave, equiparado a hediondo na Lei Penal, o que denota a impossibilidade, por ora, de os jovens permanecerem no convívio social, conforme Art. 174, parte final do ECA. Anote-se que Matheus VII é multirreincidente... (João VI)

A menção ao caráter hediondo do crime de tráfico remete à Lei 11.343, editada no ano de 2006 e que instituiu o Sistema Nacional de Políticas Públicas sobre Drogas, prescreveu medidas preventivas quanto ao uso indevido, regulou as formas de atenção e reinserção social de usuários e dependentes de drogas; estabeleceu normas para repressão à produção não autorizada e ao 
tráfico ilícito de drogas; definiu crimes dentre outras providências (BRASIL, 2006). A este respeito, retomamos o capítulo em que discutimos a questão das drogas e a Socioeducação, na qual intentamos traçar um breve panorama da droga mercadoria (Rocha, 2015), do caráter transnacional das organizações criminosas ligadas ao tráfico de entorpecentes e da relação de complementariedade que se estabelece entre a ausência do Estado nas periferias e a atuação violenta do comércio de substancias ilícitas nas periferias das cidades latino americanas. (citação

Após um longo período de tramitação nas Casas Legislativas brasileiras, os diversos projetos de Lei, que versavam sobre substancias entorpecentes ilícitas, sofreram adaptações e modificações que resultaram no texto final da lei 11.343, a qual, em suma, despenalizou o usuário de drogas retirando a pena privativa de liberdade do rol de sanções previstas substituindo-as por penas alternativas, o que representou um avanço na direção de uma nova política de drogas, uma vez que retira o uso destas substancias do controle sóciopenal (Boiteaux, 2006).

Entretanto, no que se refere ao crime de tráfico, esta legislação endureceu as punições aumentando o tempo de reclusão, sob a justificativa de um controle maior sobre o comércio de drogas, o que na prática, incidiu fortemente sobre o varejo destas substancias ilícitas, resultando num aumento do número de encarceramentos por este tipo penal desde a aprovação da lei e uma redução estatísticamente pequena nos números de prisões por posse ou uso (Boiteaux, 2006). Ou seja, antes da lei 11.343, consumidores de substancias ilícitas já não representavam uma parcela significativa das prisões, uma vez que, nesta categoria, desde as décadas de 1970 e 1980, estudos apontam a emergência do paradigma médico como argumento legitimador da substituição das penas de reclusão por outras sanções não restritivas de liberdade, especialmente quando o réu da ação pertencia a determinados estratos sociais mais privilegiados. Entretanto, para os pequenos traficantes, que atuam na ponta da comercialização e se originam, predominantemente de regiões periféricas com alto índice de violações direitos, o número de encarceramentos aumentou substancialmente nos anos seguintes da aprovação da Lei de 2006. (Batista, 2010)

O encarceramento em massa, bem como o endurecimento de legislações sobre o tema se alinham perfeitamente a política bélica de guerra às drogas, capitaneada pela Organização das Nações Unidas e pelos Estados Unidos da América, entretanto no que se refere a seus resultados 
efetivos no combate ao comércio ilícito e seus possíveis efeitos benéficos à saúde pública não puderam ser comprovados passados quase uma década da aprovação da referida Lei. Já o caráter de criminalização de determinada parcela populacional pode ser percebido como a verdadeira função deste tipo de arcabouço legal, uma vez que seus efeitos punitivos recaíram especificamente sobre aqueles mesmos já atingidos pela histórica exclusão socioeconômica. (Rocha, 2015)

Para a realidade social, além das questões do aprisionamento, o estigma atribuído a figura do traficante também fora reforçado neste processo, por meio do Instituto do caráter hediondo acrescido pela lei 11.343 a este tipo penal, dado recorrentemente retomado por nossos promotores nas Representações analisadas. Esta marca jurídica sobre determinada prática social revela sua intenção de situar, não somente as ações mas, fundamentalmente, seus sujeitos num campo de reconhecimento social atrelado à uma noção de periculosidade inerente ou potencial (Rocha, 2015).

(...) Atualmente, a nova lei de tóxicos classifica como hediondo o crime de tráfico de entorpecentes (...) Não obstante os Institutos do Direito penal e processual penal não guardarem relação matemática e linear com aqueles da justiça menorista, forçoso o reconhecimento da vontade do legislador e da sociedade que representa, ao editar a tal lei de crimes hediondos, no sentido ao endurecimento a este tipo de delito. (...) João II

Em sua pesquisa de doutoramento em Serviço Social, acerca do tema do proibicionismo e da criminalização de adolescentes pobres por tráfico de drogas, realizada na Universidade Estadual Paulista Julio de Mesquita Filho - UNESP no ano de 2012, Andréa Pires da Rocha já houvera constatado nas decisões de atores do Poder Judiciário este fenômeno da estigmatização de adolescentes e jovens oriundos de classes sociais periféricas nos processos relacionados ao transporte ou comercialização de substancias ilícitas. A referida autora aponta a reprodução de um discurso do senso comum e a ausência de uma compreensão histórica deste tipo de crime, do contexto territorial e da dinâmica social na qual as relações do narcotrafico se inserem nessas comunidades. 
A referida pesquisa fora realizada no contexto das rotas de transporte ilícito do estado do Paraná, considerando suas especificidades fronteiriças, entretanto, as conclusões alcançadas pela referida autora traçam um paralelo substancial com nossos dados de pesquisa. Em específico nesta categoria em que analisamos um recorte da atuação do Ministério Público Paulista em processos similares:

(...) Destarte, é preciso requerer a decretação da internação provisória dos adolescentes. Trata-se de fato grave, praticado em circunstâncias que denotam a impossibilidade, por ora, dos menores permanecerem no convívio social (...) (João III)

Nestes trechos podemos encontrar um procedimento bastante recorrente, ao menos como restou demonstrado em nosso recorte de pesquisa, quando do recebimento de adolescentes que cometem atos infracionais equiparados a tráfico de entorpecentes junto ao Ministério Público do Departamento de Execuções da Infancia e Juventude na capital paulista, em sua maioria apreendidos por envolvimento no varejo da comercialização destas substancias. Em grande parte dos relatos analisados, a expressão que indica a impossibilidade do convívio social é evocada para embasar o requerimento de privação de liberdade nas peças de Representação.

Nas alíneas da lei 8.069, que instituiu o Estatuto da Criança e do Adolescente, em especial nos Artigos 121 e 122, a qual dispõem sobre a medida socioeducativa de internação, não encontramos uma definição ou mesmo menção à este conceito de impossibilidade da convivência social. Encontramos apenas, no segundo artigo a menção quanto as condições que ensejam a determinação da referida sanção (Brasil, 1990). Em contraponto, encontramos também um discurso mais amplo, que retoma a argumentação acerca da manutenção da Ordem Pública, acrescentando ainda a percepção pessoal do promotor acerca do problema do tráfico e suas dimensões na sociedade brasileira.

(...)O tráfico de entorpecente coloca em risco a ordem pública, estando autorizada a internação provisória (...) 
(...) Faço consignar que o presente delito é o grande mal da sociedade contemporânea, atingindo de forma difusa um número inimáginavel de pessoas e famílias, além de estar associado, na maioria dos casos, à criminalidade organizada. Equiparado a delitos hediondos por Lei Federal editada pelo legislador é, por consequência, insuscetível de fiança e liberdade provisória em que pese a ausência de violência ou grave ameaça. (...) (João II)

No relato de João II, o ator do Sistema de Justiça indica a relação entre crimes relacionados a substancias normativamente proibidas e a Organizações criminosas, não indicando entretanto, a posição do adolescente nesta rede criminal. Diversos autores discutem a participação de jovens nas redes do narcotráfico postulando sua participação na ponta enquanto vulnerável e distante dos ganhos daqueles que ocupam funções mais elevadas na hierarquia do comércio ilegal. Destacam a volatilidade destas atuações, bem como a seletividade do sistema de justiça, a qual se concentra majoritariamente sobre este setor das redes do tráfico.

Em outro recorte, podemos encontrar uma construção de justificativas para fundamentar a decisão do Promotor, na qual, são retomados aspectos do percurso pessoal do adolescente na sua relação com a atividade ilícita. Diferente dos demais este relato fora obtido a partir de seu depoimento, quando de sua internação provisória, anterior aos procedimentos de julgamento e imposição da sanção, ou seja, este argumento é retomado para subsidiar uma nova medida de privação de liberdade, esta agora, por um período maior que a anterior:

(...) Note-se que o adolescente relatou na Fundação CASA (o representante do Ministério Público cita o relatório da técnica da unidade provisória de internação a qual fora encaminhado o adolescente, logo após o ato infracional e antes da realização desta Representação, todavia na pesquisa de campo não fora possível obter a transcrição deste documento) que há sete meses alugou uma casa onde esta residindo com sua companheira. Ocorre que nenhum dos dois tem emprego (formal ou informal) para garantir o pagamento das despessa domésticas, o que autoriza a conclusão de que o adolescente vem se sustentando e a sua companheira, com 
dinheiro proveniente do tráfico. (...) A desestrutura social do jovem demonstra que, se for solto, sem a devida intervenção do Estado em sua estrutura familiar, ele voltará para a prática do tráfico. (...) (João V)

A informação quanto ao uso do dinheiro por parte do jovem réu no processo socioeducativo, dinheiro este proveniente do trabalho no comércio de drogas é utilizado como demérito de sua conduta, ainda que a destinação da renda tenha sido uma necessidade fundamental, como a moradia. Esta decisão, ainda que isolada de aspectos singulares do adolescente, revela um circuito de penalizações que excedem a redação do texto legal. Mais uma vez, retomando os artigos do ECA que referem os requisitos legais para imposição da medida socioeducativa de internação, não encontramos paralelo a esta aplicação dos artigos da referida lei e, ainda que não tenhamos a pretensão de adentrar o campo da interpretação jurídica de documentos legais, é forçoso reconhecer o caráter seletivo e peculiar desta argumentação.

A discussão sobre o quanto a negação de direitos pode ser utilizada contra determinada parcela populacional remete a um controle sociopenal já descrito na literatura, em específico se considerarmos o arcabouço jurídico-normativo do Dispositivo de Proteção Integral, que se fundamenta no artigo 226 de nossa atual Constituição Federal, a qual postula acerca da responsabilidade da família, da Sociedade e do Estado quanto a defesa de direitos fundamentais ao qual a garantia de moradia se insere. Ainda quanto a este recorte, fica claro o reconhecimento do Promotor quanto a uma situação de desestrutura ou vulnerabilidade familiar, a qual, em sua perspectiva, deva ser enfrentada a partir da intervenção do Estado que se materializa no afastamento do convívio familiar de João V.

Prosseguindo nossa análise dos dados adentramos uma terceira categoria elaboradas a partir das narrativas de audiências de apresentação e conclusão, as quais sucedem as peças de representação, conforme a organização das pastas técnicas analisadas. Deste modo, nossa estudo se dirige agora para a parte final do processo de ingresso destes adolescentes nos processos de ressocialização, tendo como eixo aglutinador a atuação no comércio varejista de drogas ilícitas. 
Neste recorte, após a apresentação de algumas passagens que representam parte do processo, tal qual realizamos nas categorias anteriores, objetivamos a indicação de algumas posições ou posturas ideológicas, uma vez que entendemos que a análise destas decisões não possa ser meramente definida entre o reducionismo de dois pólos Doutrinários, a saber, o menorismo e a Proteção Integral. Sposato (2006) aponta a complexidade em se definir em nosso Sistema de Justiça Juvenil um caráter uniforme a qual, segundo a autora, deve-se entre outros fatores, a permanência de traços da doutrina menorista tutelar nas práticas socioeducativas. A coexistência entre doutrinas no cenário da Justiça da Infância e da Adolescência aponta uma dimensão hibrida das atuações dos operadores do direito, marcada por matizes na qual a punitividade de ato e de autor se misturam na interpretação e exercício das leis (Gomes, 2012).

Outro aspecto a qual ainda provoca essa percepção quanto a impossibilidade de uma responsabilização plena a qual propõe o ECA se deve a seu caráter heterogêneo, uma vez que junto ao paradigma garantista podemos encontrar traços de outros modelos de Justiça Juvenil em suas definições. Retomando a história constitutiva das práticas legais junto a Infancia e Juventude podemos apontar quatro etapas que indicam padrões de atuação junto a esta população, a saber, a etapa penal indiferenciada, o modelo de proteção ou tutelar; o modelo educativo de de Bem Estar e o modelo de responsabilidade ou etapa garantista (Sposato, 2006).

Sendo assim, construímos categorias intermediárias baseadas nas respostas dos magistrados e na vasta literatura sobre o tema, de maneira que consigamos uma aproximação da realidade na qual legislam os operadores do direito na Socioeducação. Acreditamos que esta classificação mais ampla possibilita uma emergência mais atual do campo de práticas na Justiça Juvenil.

Prosseguindo nossa análise apresentamos agora um grupo de decisões a qual, não se vincula diretamente a um dos estágios ou Doutrinas da Justiça Juvenil, ou ainda, a qual se coloca num entreposto que lhe permite não se filiar nem a um garantismo pedagógico ou a um menorismo tutelar. Em comum, estas decisões trazem uma retomada de uma postura tradicional, na qual o 
modelo de Estado incide preponderante sobre este embate doutrinário, oferecendo ao magistrado uma posição de superioridade e de segurança em suas decisões.

(...)A custódia provisória autorizada pelo artigo 108 do ECA, constitui medida cautelar que não se vincula necessariamente às hipóteses do artigo 122 do mesmo Estatuto, dependendo apenas da constatação de sua necessidade imperiosa, como ocorre na espécie, em que se busca resguardar também, além da ordem pública, a própria segurança do infrator, o qual deve ser imediatamente afastado dos apelos criminógenos do meio. (...) (João II)

Não obstante os Institutos do Direito penal e processual penal não guardarem relação matemática e linear com aqueles da justiça menorista, forçoso o reconhecimento da vontade do legislador e da sociedade que representa, ao editar a tal lei de crimes hediondos, no sentido ao endurecimento a este tipo de delito.

Sendo que o desprezo pelo julgador, seja sob qual pretexto for, atenta não só contra a lei em sí, mas principalmente contra o Estado Democrático de Direito que jurou defender. (João II)

(...) forçoso o reconhecimento da vontade do legislador e da Sociedade que representa ao editar tal Lei de Crimes Hediondos, no sentido de um endurecimento maior no combate a este tipo de delito, sendo que seu desprezo pelo julgador, seja sob qual pretexto for, atenta não só contra a lei em si, mas principalmente contra o Estado Democrático de Direito que jurou defender. (...)(João VII)

Na decisão da audiência de João II podemos encontrar a referencia ao Estado Democrático de Direito após uma longa explanação sobre a questão das drogas e a lei 11.343 de 2006, a qual voltaremos a discutir mais adiante. Entretanto, esta expressão mostrou-se recorrente em algumas decisões observadas, tal como um conceito âncora, a qual o magistrado recorre para indicar um determinado princípio ou posição, por isso a determinamos como nossa primeira categoria de posições. A referida expressão fora utilizada num contexto que se apresenta diverso do garantismo, ou que se pretende, numa relação hierárquica, se afirmar preponderante ante àquela legislação. Em nossa amostra, esta expressão fora sempre utilizada num contexto de 
reafirmação ou legitimação de um constructo diante possíveis indagações à sua pertinencia, no caso específico, da Lei supra citada, em detrimento ao constructo da Proteção Integral.

Sob nossa perspectiva, a postura desta decisão não aponta para uma viés tutelar da Infância, uma vez que seu argumento legitimador poderia ser aplicado perfeitamente à justiça criminal, a qual aliás o magistrado recorre para destacar pontos da natureza desta tipificação penal. Tampouco podemos dizer que esta decisão aponta para um caráter garantista ou educativo em sua composição, uma vez que a retomada do Estado Democrático de Direito na narrativa aponta para um modelo de construção da Lei apoiado na clássica representação política do legislador.

Passemos a outra categoria de decisões, a qual nomeamos de Posição Tutelar-

\section{Correcional:}

Sentença: o jovem não estudava e trabalhava com familiar, sem formalização (...) a família não foi capaz de conte-lo(...)

Têm razão a promotora ao destacar a quantidade expressiva de drogas apreendidas, indicando escala na comercialização e largo envolvimento com o crime organizado (João II.2)

(...)Trata-se de ato infracional extremamente grave, equiparado a crime hediondo previsto na Lei 11.343/2006 (...) o que autoriza a internação provisória... a fim de resguardar a segurança do adolescente, que deve ser imediatamente afastado das causas que ensejaram a conduta inadequada (...) (João IV)

No primeiro recorte de sentença ressaltamos o alcance de nossas inferências dada a incompletude da narrativa, todavia apontamos algumas argumentações que indicam uma posição decisória que se alinha à Doutrina Tutelar de justiça juvenil, naquilo em que esta compreende o inimputável enquanto passível de cuidado, de contenção, a qual a família, eleita a primeira, dentre as tres instâncias responsáveis pela garantia dos direitos fundamentais de crianças e adolescentes (Brasil, 1988), não fora capaz de faze-lo. 
No segundo recorte, o magistrado aponta a necessidade de resguardar a segurança do adolescente, considerando que a única medida possível seria apartá-lo do convívio com o meio infracional, tal qual postula também o ECA, afirmando a concepção de que, o adolescente não sendo capaz de se responsabilizar por seus atos e de julgar adequadamente aspectos de sua realidade social estaria autorizada a internação provisória atendendo os princípios da Proteção Integral.

A noção de contenção também remete a uma incapacidade ou enfermidade, para a qual se justifica um tratamento e não um castigo, e nesta perspectiva, o fato de a medida não comportar prazo para sua duração, sendo observada a avaliação por especialistas tais como psicólogos ou psiquiatras reforça esta ideia de tratamento que é a marca do paradigma tutelar (Sposato, 2011).

Vejamos outra decisão:

A despeito de primário, o adolescente não apresentou arrependimento e demonstrou vulnerabilidade ao meio social (...) Não possui amparo familiar, residindo com a irmã de apenas 19 anos, sendo que os pais moram no exterior; Não comprovou frequencia em estabelecimento de ensino, por fim a internação é de rigor.

A autoria também restou comprovada pela prova oral (Boletim de Ocorrência) constante dos autos, senão vejamos. Ouvido em juízo, o adolescente negou a prática do ato infracional. No entanto a prova testemunhal (as testemunhas são os policiais que realizaram a abordagem) confirmou a ocorrência do ato infracional (...)

(...) Ressalte-se que o adolescente já permaneceu internado provisoriamente por 33 dias, período no qual a medida lhe impactou. (João III)

Esta decisão se refere a uma audiência de continuação, a qual é indicada pelo Juiz da Infância logo no início dos trabalhos da audiência de apresentação. Numa definição leiga, é a segunda audiência pela qual os adolescentes passam em seu processo ressocializador, em geral sucede um período de privação de liberdade nas unidades de internação provisória localizadas nas adjacências do prédio do DEIJ. Neste processo específico não fora possível afirmar se o Juiz que presidia esta audiência fora o mesmo que houvera presidido a audiência de apresentação, todavia 
em outras pastas consultadas e da experiência profissional na socioeducação, um magistrado não preside as audiências de apresentação e continuação de um mesmo adolescente.

Nesta narrativa, após alegações da Defesa do adolescente e da posição do Ministério Público, o Juiz inicia suas argumentações apontando a questão do arrependimento e da vulnerabilidade ao meio social. A expectativa não observada pelo magistrado, quanto a reconsideração do adolescente diante seus atos nos aponta direções quanto a possíveis doutrinas que ensejam o entendimento desta atuação na justiça juvenil: "a medida imposta por isso deve penetrar em sua alma, para lograr arrependimento e logo sua correção” (Sposato, 2011, p.78).

Todavia, os motivos que complementam a referida explanação aproximam definitivamente esta postura decisória de um modelo tutelar de justiça da infância e adolescência, assim nomeamos esta categoria como Tutelar-Garantista. Em seu arrazoado sobre a sanção imposta os quesitos ausentes do amparo familiar e da comprovação da frequência escolar conduzem a uma internação de rigor. Ao final de sua exposição, ressalta o período de sanção, externando sua avaliação positiva quanto ao resultado alcançado neste espaço de tempo sob os cuidados do Estado, representado pela Instituição responsável pelas sanções de internação e semiliberdade, nesta perspectiva "Os dispositivos correcionais se dirigem à modificação do sujeito, à modificação de sua consciência e não à reprovação do fato delitivo” (Sposato, 2011, p.79). Esta decisão se destaca das demais analisadas por seu caráter excepcional na construção argumentativa que embasa a conclusão tomada, as quais escapam da redação literal do ECA como observada na maioria das demais decisões.

A construção do rol de medidas socioeducativas trazidas pela Lei 8.069 compõe uma hierarquia de sanções que atendam aos objetivos pedagógicos e responsabilizadores a qual o Estatuto propôs como resposta adequada para os conflitos resultantes da intersecção juventude e atos infracionais. Assim, sanções menos restritivas de direitos foram inclusas na perspectiva de oferecer ao julgador uma gama maior de respostas aos delitos cometidos por aqueles em situação peculiar de desenvolvimento, reservando as sanções mais gravosas para situações específicas na qual todas as outras não se mostraram eficazes, dentre outras condições apontadas no Artigo 122 da referida legislação. 
No curso da pesquisa de campo, os embates relacionados à interpretação e à aplicação deste ponto especifico do ECA foram recorrentes. As discussões em geral envolviam Defensores e Juízes; Os primeiros alegam, de forma recorrente, a inexistência da condição fundamental para a decretação da sanção de privação de liberdade, o delito ter sido cometido sem o uso de violência ou grave ameaça (Brasil, 1990). Por sua vez os juízes constróem suas argumentações, demonstrando, ainda no texto do ECA, o embasamento de suas decisões favoráveis à internação:

(...) defiro em parte o requerido pelo MP e decreto a internação do representado Matheus VII, o que faço com fundamento no Art. 184 caput, c.c Art. 108, ambos do ECA. Requisito-se com urgência, vaga em unidade adequada da Fundação CASA. (...) (Matheus VI)

(...) Decreto a internação provisória dos jovens, tendo em vista a manifestação do MP e que o tráfico coloca em risco a Ordem Pública, estando autorizada a internação provisória, nos termos do Artigo 174 do ECA. (...) (João VII)

(...) Estando presentes indícios de autoria e materialidade, recebo a representação. Decreto a internação provisória do adolescente Judas VIII, residente à $R$ : X, nos termos do Art. 108, Parágrafo único, c.c Art. 122, inciso II, ambos do ECA. Ressalto que a medida é imperiosa, para garantia da segurança social do (o) (a) adolescente, bem como para manutenção da ordem pública e considerando ainda, a repercussão social do ato infracional. (...) (João VIII)

A explanação dominante nas pastas técnicas que pesquisei, a qual embasa a discordância por parte dos magistrados acerca a tese da defesa dos adolescentes, de que o delito de tráfico não fora cometido sob violência ou grave ameaça, remete fundamentalmente a dois pontos do ECA, a saber, o Artigo 174 e o Artigo 184. Transcrevo a seguir a redação dos referidos artigos abaixo, e também o Artigo 108 citado juntamente com este último: 
Art. 108. A internação, antes da sentença, pode ser determinada pelo prazo máximo de quarenta e cinco dias.

Parágrafo único. A decisão deverá ser fundamentada e basear-se em indícios suficientes de autoria e materialidade, demonstrada a necessidade imperiosa da medida.

Art. 174. Comparecendo qualquer dos pais ou responsável, o adolescente será prontamente liberado pela autoridade policial, sob termo de compromisso e responsabilidade de sua apresentação ao representante do Ministério Público, no mesmo dia ou, sendo impossível, no primeiro dia útil imediato, exceto quando, pela gravidade do ato infracional e sua repercussão social, deva o adolescente permanecer sob internação para garantia de sua segurança pessoal ou manutenção da ordem pública.

Art. 184. Oferecida a representação, a autoridade judiciária designará audiência de apresentação do adolescente, decidindo, desde logo, sobre a decretação ou manutenção da internação, observado o disposto no art. 108 e parágrafo.

A redação dos três artigos citados contém o vocabulário dominante nas decisões que afirmam a necessidade da internação do adolescente apreendido no comércio de substâncias entorpecentes ilícitas. Ainda que a interpretação de uma legislação remeta ao espirito do Direito, a existência desta exceções a uma regra postulada na mesma legislação aponta um caráter ambíguo presente nas alíneas do Estatuto da Criança e do Adolescente - ECA, a qual possibilita uma atuação discricionária que possibilita a existência de diversas racionalidades em sua aplicação nas Varas da Infância pelo País. (Costa, 2005; Souza, 2013; Maruschi, Estevão \& Bazón, 2013).

Apresentamos a seguir outra decisão a qual sob a análise de seus aspectos constitutivos indica um caráter mais próximo das Doutrinas existentes no início das praticas na Justiça Juvenil, ao mesmo tempo que recorre ao Instituto da reeducação e da correção para resposta ao conflito. por isso a nomemamos de Posições menorista-correcional. 
As linhas iniciais do julgamento do magistrado poderiam fazer parte de uma sentença no âmbito da justiça criminal, uma vez que a análise impetrada pelo Juiz não desconsidera o adolescente em sua capacidade ou responsabilidade, ainda que a tome no sentido de ressaltar a imperiosa necessidade da internação diante suas escolhas e habitualidade no meio do crime:

(...) Matheus VII que já é reincidente e já habitual ao meio do crime, admitiu em juízo o tráfico de drogas - parou de estudar na $5^{\circ}$ série; Confessa que estava traficando neste dia; Começou vendendo drogas naquele dia; (...) Evidente que, negou a habitualidade. (...)

(...) No âmbito da Fundação CASA admitiu que estava traficando para aquisição de vida e bens materiais - a frequência de balada e roupas de marca. Como adiantaram as partes, o simples concurso de agentes prevaleceu sobre a ausência de estabilidade de associação criminosa.

Ao mesmo tempo, aponta a frouxidão da legislação do ECA em seus institutos que não se aproximam dos efeitos alcançados pela medida privativa de liberdade, pois a consonância com a realidade vigente entra nos sistema socioeducativo como aspecto legitimador da necessidade da adoção desta medida mais gravosa diante o delito de tráfico, e encerra com a indicação da importância do dispositivo de privação de Liberdade na proteção ao adolescente e, diferente das decisões anteriores de caráter tutelar, também para a Sociedade:

Passo a aplicar a medida socioeducativa. Não se pode adotar um critério gradual e aritmético para alcançar uma ressocialização institucional. Seria irresponsavelmente autorizar a prática reiterada de infrações, com condenações, para a proteção efetiva do vulnerável.

A medida prejudica o menor.

O fim primordial da medida socioeducativa é protetiva e não punitiva, através da reeducação do adolescente em risco, vivenciando o meio infracional, de forma a alcançar 
resultados benéficos, através dos princípios da intervenção precoce, brevidade $e$ proporcionalidade, da atualidade e da proteção integral - Art. 100 da Lei 8. 069/90. A imposição da medida socioeducativa de internação é o único meio, pela frouxidão e inexistência de legislação mais eficaz, em consonância com a realidade vigente, para que o adolescente possa compreender a gravidade dos atos praticados e receber os encaminhamentos necessários a uma efetiva socialização.

Não se confunde com o direito penal ou punitivo, não se cogitando de pena a forma de sua execução. O objetivo não é a punição do infrator, mas reeduca-lo ou ressocializá-lo.

Concluindo, a medida de internação a Matheus VII não representa punição, mas essencial mecanismo de proteção ao jovem e à Sociedade. (Matheus VI)

Esta decisão se aproxima de nossa próxima categoria todavia, optamos por abordá-la em separado, uma vez que esta trazia a peculiaridade de seu viés que aponta para o paradigma menorista em sua abordagem do conflito envolvendo a adolescência e a juventude. A construção narrativa do Juiz, entendendo por necessário salientar que sua decisão não tem viés de punição e (...) não se confunde com o direito penal ou punitivo, não se cogitando de pena a forma de sua execução (...) (Juiz VI). A proteção efetiva a qual propõe a sentença se inscreve numa estratégia disciplinar que desconsidera a dupla violência a qual estes jovens estão inseridos; De um lado, excluídos dos direitos sociais básicos por um Estado penal que nunca se consolidou na direção do Bem-estar Social para estes underclass, e por outro, inseridos nas redes de exploração e vitimização que a organização transnacional do trafico de entorpecentes representa nas periferias (Batista, 2010, Dieter, 2012, Rocha, 2015)

A tecnologia da disciplinarização dos corpos adolescentes, iniciada pela abordagem policial e agora reatualizada nas redes processuais de um sitema de justiça juvenil de autor (Gomes, 2012), na qual a negação de direitos, a saber, as questões do acesso de jovens periféricos ao mundo do trabalho, o efeito sedutor que a indústria transnacional do tráfico representa para a juventude das margens do capitalismo, não encontra lugar de visibilidade diante uma demanda 
por garantia da Ordem Social a qual se espera da prática da magistratura nos conflitos envolvendo Infância e adolescência. Nesse sentido, para o operador do Direito que ingressa nas tramas da Socioeducação, uma das grandes possibilidades de exercício de sua função reside na capacidade de atuar com a lei (...) para que o adolescente possa compreender a gravidade dos atos praticados e receber os encaminhamentos necessários a uma efetiva socialização (...) (Juiz VI). Na lógica dos embates travados entre diferentes modelos de justiça juvenil, a qual estão inscritas as narrativas decisórias destes Juizes, a vulnerabilidade de determinada parcela populacional pode, ao preço da ressocialização, depor contra sí mesma, na busca por Justiça e Responsabilização (Abramovay et. Al., 2010; Batista, 2010).

Encerrando esta análise de gradientes situados nas praticas cotidianas da Justiça Juvenil, construída a partir de posições perceptíveis nas narrativas dos processos de apresentação e continuação, apresentamos um ultimo grupo de recortes, agrupados por suas características mais próximas ao modelo de responsabilização presente no Estatuto. Como já apontado, a discussão sobre um modelo genuíno de garantismo ou mesmo a extensa produção acadêmica sobre os conflitos existentes nas alíneas da Lei 8.069 não recomendam uma análise que se idealize ou que obstrua as possibilidades de diálogo na complexidade das práticas socioeducativas (Sposato, 2011).

Sendo assim iniciamos essa analise de narrativas nesta categoria discutindo a transcrição que traz menos conteúdo, no sentido da coleta de dados, dentre todas as narrativas analisadas. Para esta discussão, cumpre retomar nosso diário de campo da coleta documental junto ao Cartório do DEIJ a qual, para além do acesso aos dados objetivos das pastas técnicas, pode nos informar muito sobre o ambiente na qual estas histórias se desenvolvem. O exercício da aproximação com o campo e de inserção num território a qual é atravessado por dispositivos de controle e resolução de conflitos, fora se desenvolvendo e se refinando ao longo das sessões de transcrição, ou seja, nas últimas sessões de transcrição, nosso conhecimento das minúcias e regras do funcionamento de um cartório se mostravam muito mais avançadas que nos primeiros contatos. 
Em especial nesta pasta técnica, a qual tentamos retornar por diversas vezes, reconhecemos a fulgacidade do processo socioeducativo, a qual historias singulares são contadas diariamente, mas que se inscrevem numa lógica temporal fulgaz, ao menos para uma análise sob a perspectiva da Psicologia Social, em que a manutenção do fluxo dos ritos processuais é uma prioridade extremamente presente e ao mesmo tempo velada, tal como o clima que se pressente nas salas e corredores do prédio da Rua Piratininga.

Retomando nosso recorte apresentamos alguns trechos da decisão de João I:

(...) Considerando (...) a prática infracional admitida, a sincera disposição em não mais infracionar e a menor potencialidade ofensiva da conduta (...) A medida consensualmente proposta: liberdade assistida pelo prazo necessário à ressocialização, cujos objetivos são: Escolarização; Profissionalização e documentação (...) (João I).

Talvez este trecho represente o reflexo material mais próximo de uma prática garantista, no contexto dos atos infracionais equiparados ao delito de tráfico de drogas, a qual tivemos acesso em nossa incursão à dinâmica de relações e narrativas no campo socioeducativo da cidade de São Paulo no estrato histórico de nossa pesquisa. Esta afirmação se fundamenta menos nos conteúdos narrados que na potência de resistência e afirmação que esta sentença representa. Tais como esta, muitas decisões, muitas tomadas de posição devem surgir cotidianamente nas audiências e oitivas do DEIJ, entretanto, são silenciadas sob o jogo de forças das técnicas de controle sóciopenal e não publicizadas tais como aquelas que, mesmo do lugar do denunciado, se reafirmam e reatulizam na estratégia neoliberal de manutenção das hierarquias sociais.

A seguir transcrevo outras decisões para nossa analise, vejamos:

(...) É o relatório. Decido. O adolescente confessou a prática do ato infracional. Não possuí ele respaldo familiar adequado para desenvolver seus freios inibitórios. Deflui-se dos elementos contidos nos autos que tal medida é suficiente para o processo de ressocialização do jovem, servindo a contenção para que ele tenha acompanhamento dos técnicos da Entidade de abrigamento, bem como a momentos de liberdade para que se reintegre à Sociedade. Não se 
pode olvidar, outrossim, que receberá também cursos profissionalizantes, além da continuidade da instrução básica obrigatória.

Por tais razões, a medida de semiliberdade é a que melhor se adéqua a espécie, afastando-se eventuais outras medidas em meio puramente aberto e que não serviriam aos propósitos supra mencionados. (...) (João VII)

Vistos. 1) Ao oferecer representação, o MP pugnou pela decretação da internação provisória dos adolescentes. O pedido comporta parcial deferimento

Matheus VIII possui passagens anteriores pela suposta prática de atos infracionais equiparados aos crimes de roubo majorado e furto, sendo certo que esta em cumprimento de medida socioeducativa de liberdade assistida e, nesta data, foi recebida outra representação em seu desfavor, pela suposta prática de novo ato infracional, desta feita análoga ao crime de furto qualificado.

Tais circunstâncias pessoais aconselham a decretação da internação provisória do representado Matheus VII, sendo tal medida necessária para a garantia da segurança pessoal do adolescente, evitando-se que se coloque em situação de risco pela prática de novos atos infracionais. Por esses motivos, defiro em parte o requerido pelo MP e decreto a internação do representado Matheus VII (Matheus VII)

Estes recortes de decisões nos indica outras possibilidades de praticas socioeducativas no tema das infrações relacionadas ao varejo das drogas. Ainda que reitere em seu conteúdo muito da percepção que já observamos em outros recortes, dois pontos se revelam dignos de consideração no contexto estrito e pouco permeável a mudanças das decisões nas Varas da Infância. O primeiro se refere a concordância parcial com as indicações do Ministério Público por parte do Juiz da Apuração, algo que nas pastas técnicas que consultamos desde o início da coleta de campo, fora um fato bastante raro nas audiências de apresentação. O segundo ponto a qual nos 
debruçamos consiste numa organização de argumentos apresentadas pelo magistrado a qual difere das narrativas anteriores.

Aqui podemos perceber uma espécie de calculo na decisão, uma progressão de sanções as quais resultam na imposição da sentença mais gravosa. Não são indicados aspectos morais ou longas analogias interpretativas para proteger a sentença, a qual refleta uma postura que almeja uma neutralidade diante deste embate que conclama o juiz da Infancia a tomar uma posição entre os pólos delimitados do menorismo e da Proteção Integral.

Por fim, apontamos outra questão fundamental evidenciada em nossa proposta de investigação, a qual se refere a oferta da prova testemunhal para confirmação de uma conduta infracional. A este respeito apresentamos alguns dados obtidos em campo:

A autoria também restou comprovada pela prova oral (Boletim de Ocorrência) constante dos autos, senão vejamos. Ouvido em juízo, o adolescente negou a prática do ato infracional. No entanto a prova testemunhal (as testemunhas são os policiais que realizaram a abordagem) confirmou a ocorrência do ato infracional (...)

Com efeito, as testemunhas ouvidas apresentaram relato com riqueza de detalhes quanto à caracterização do ato infracional. O policial reconheceu o adolescente; disse que havia denuncia com ordem de serviço para a viatura permanecer no local dos fatos. Ali o adolescente foi abordado com outros indivíduos; Somente o adolescente estava com drogas.

(...) A versão apresentada pelo adolescente não prospera e não autoriza a improcedência da pretensão ministerial, que sugere a medida de internação para o adolescente, porque além de pouco crível e contraditória, não encontra respaldo em nenhum elemento de informação ou prova produzida. (João III)

Com efeito o adolescente foi apreendido quando trazia consigo quantidade considerável de substâncias causadoras de dependência física e psíquica, conforme relato dos policiais que, 
até prova em contrário, merecem total credibilidade, havendo grande probabilidade de tal substância se destinar à venda e para consumo de terceiros... (João III)

Evidente que, negou a habitualidade. Os policiais explicaram que o serviço reservado investigou e examinou a situação, indicando ao serviço ostensivo o flagrante. Não estão impedidos pela simples condição de policial - Art. 202 do CPP (Código de Processo Penal). Toda pessoa poderá ser testemunha. A simples condição de policial não torna a testemunha suspeita. Não se concebe a simples e gratuita alegação de que o depoimento dos policiais deve ser recebido com reservas. Como todo e qualquer testemunho, deve ser avaliado no contexto de um exame global de provas. (João VI).

Nestes recortes podemos observar uma narrativa que poderia ser atribuída às classificações desenvolvidas por Jesus (2012), em sua pesquisa sobre este mesmo fenômeno no contexto dos adolescentes e jovens utilizados como mulas pelo trafico na fronteira Brasil e Paraguai. O quadro composto pela autora aponta desde uma crença na conduta e na narrativa policial, como também uma descrença nas versões dos acusados, esm especial oriundos de camadas populares menos privilegiadas. Na pasta técnica não encontramos indicação de outras providências na direção de uma investigação sobre a alegação do adolescente, ao mesmo tempo, a riqueza de detalhes apresentada pelo policial legitima sua versão dos fatos. No outro recorte,o magistrado indica a total credibilidade reservada ao relato policial, o que reitera a noção de fé pública a qual as condutas policiais são revestidas, ou ainda nas palavras de Acácio Augusto: "Hoje, expande-se o amor à polícia como instituição ao mesmo tempo que o exercício da cidadania se assemelha a condutas policiais” (Junior, 2009, p. 8)

Outra temática a qual optamos por abordar em separado se refere ao discurso dos operadores da Justiça acerca o delito de trafico e suas implicações na imposição de uma sanção socioeducativa. (...)

Vejamos estes trechos: 
Estão presentes indícios de autoria e materialidade, o que não sustenta a versão do adolescente de que, fora incriminado e, na ocasião dos fatos, não praticava a traficância, ainda que em outros momentos admite já o ter feito (...). (João II)

Como já discutido anteriormente, quando o dispositivo policial de controle de populações periféricas é acionado, se torna invisível qualquer discurso que busque contradize-lo e no caso das infrações cometidas no varejo das drogas, a atribuição de culpa é extensiva à condutas anteriores praticadas pelo adolescente, ou seja, é descartada a necessidade do flagrante pois a associação do adolescente as fileiras do narcotráfico, independente da posição inferior que ocupe na hierarquia, constitui motivação suficiente para torna-lo inimigo e passível de uma punição de rigor. Prosseguindo ainda na mesma decisão:

Faço consignar que o presente delito é o grande mal da sociedade contemporanea, atingindo de forma difusa um número inimáginavel de pessoas e famílias, além de estar associado, na maioria dos casos, à criminalidade organizada. Equiparado a delitos hediondos por Lei Federal editada pelo legislador é, por consequência, insuscetível de fiança e liberdade provisória em que pese a ausência de violência ou grave ameaça. Atualmente, a nova lei de tóxicos classifica como hediondo o crime de tráfico de entorpecentes (...) Não obstante os Institutos do Direito penal e processual penal não guardarem relação matemática e linear com aqueles da justiça menorista, forçoso o reconhecimento da vontade do legislador e da sociedade que representa, ao editar a tal lei de crimes hediondos, no sentido ao endurecimento a este tipo de delito. (João II)

Este exerto representa, de forma literal, uma argumentação recorrente utilizada pelos magistrados quando da imposição da sanção de privação de liberdade, pelo delito equiparado a conduta descrita como tráfico de entorpecentes no Artigo 33 da lei 11.343. A concepção de que esta infração representa o grande mal Social da atualidaed e o caráter hediondo atribuído a figura 
do traficante sobrepõem qualquer possibilidade de contextualização com os pressupostos da Proteção Integral. O que se revela mais contundente é uma construção narrativa a qual visa exatamente ultrapassar possíveis barreiras que o garantismo possa impor na perspectiva de punição exemplar, uma vez que esta é a conduta que se espera da justiça nesta temática, alinhada a uma legislação proibicionista que reafirma o direito penal como resposta prioritária para crimes envolvendo drogas no Brasil.

Vejamos estes outros recortes:

Como cediço, os policiais militares são agentes públicos e, por isso, os seus relatos são dignos de credibilidade, constituindo, quando seguros e coerentes, importante meio de prova. (João III)

(...) Portanto deve ser indeferido o pedido de liberação formulado pela Defensoria Pública, pois o ato infracional é extremamente grave, equiparado a crime hediondo. Está, portanto autorizada a internação provisória, a fim de resguardar a ordem pública e a própria segurança do infrator, o qual deve ser imediatamente afastado das causas que ensejaram a conduta inadequada, até que o caso seja melhor apurado. (João VIII)

O ato infracional, de péssima repercussão social, embora praticado sem violência ou grave ameaça é gravíssimo e equiparado a crime hediondo na Lei penal. O adolescente ademais, já ostenta condenações por diversos atos infracionais, tudo a denotar vida bastante desregrada e sem limites, de modo que deve ser lhe aplicada a medida socioeducativa de internação como única apta a despertar-lhe o seu senso de responsabilidade e viabilizar a sua futura inserção social (...) (João VIII)

A recorrência na construção narrativa que embasam as decisões dos Juizes das Varas de Apuração revela uma percepção comum acerca deste fenômeno, tal como apontado na 
literatura, sobre a percepção da Justiça sobre este conflito que vitima milhares de jovens nas periferias. 


\section{Conclusões}

Quando afirmamos a opção pela problematização desta temática, encampamos nossa intenção de empreender uma pesquisa sobre a adolescência em conflito com a Lei no início do percurso nos estudos de pós graduação, nossas questões principais estavam voltadas para a perspectiva de um embate, de coletar armas para o enfrentamento de um inimigo. Nosso antagonista já houvera sido eleito na experiência profissional, pelas marcas da atuação na ponta da política socioeducativa. Tratava-se da figura do Juiz, a qual em nossa a época representava a figura hierárquica responsável por decidir os destinos de nossos meninos e, na maioria das vezes, responsável por decisões injustas e desconectadas da realidade daqueles que julgava.

A diversidade de perfis dos magistrados na Justiça da Infância já fora uma questão apontada na extensa literatura sobre o tema, entretanto, para este que subscreve, fora um fenômeno que pude constatar nas atribuições profissionais que exercia, ao longo das audiências que participei, nas informações prestadas sobre o acompanhamento de medidas, enfim, nos rituais cotidianos de uma relação na ponta da política socioeducativa. Em grande parte destas experiências, para além do acompanhamento, dividiamos também a expectativa com o adolescente e seu familiar, quase sempre suas mães, sobre estas decisões. A mais difícil de todas estas era aquela que indagava se, após o julgamento, o adolescente voltaria para sua casa conosco ou não, se já deixaria seus pertences na Sala de audiências para ser encaminhado para uma das Unidades de Internação Provisória vizinhas ao edifício do DEIJ ou se poderia fazer o caminho de volta para seu bairro com uma sensação de profundo alívio e de esperanças renovadas. Em outros casos, partilhávamos também das advertências do Juiz que, como disse há pouco, fora para nós a personificação dessa variedade de condutas na Justiça da Infância e Adolescencia na cidade de São Paulo nos anos de nossa atuação.

Reconhecemos e retomamos agora estes dois aspectos pois, do ponto da pesquisa em que nos situamos a qual nos debruçamos sobre a redação das linhas finais desta incursão, temos a possibilidade de observá-las sob outro panorama ou, ao menos, reposicioná-las e liberta-las das amarras do conhecimento que se passou. Todavia, o principal aspecto que motivou, a 
substituição da perspectiva do trabalhador pelas possibilidades da pesquisa, fora mesmo a intenção em explicar a maior quantidade possível dos fatos observados pela via da investigação científica, em especial no campo da Psicologia Social, a qual pressupõe utilizar a produção de conhecimento para a transformação do cotidiano, em nosso caso específico, desses adolescentes e jovens apresentados na pesquisa, bem como de suas famílias, as quais também são punidas no processo, mesmo que inadvertidamente, assumindo deste modo, o compromisso da Psicologia com a garantia de condições dignas de vida para todos na Sociedade Brasileira. (Lane, 1980; Massola, 2005; Bock, Ferreira, Gonçalves \& Furtado, 2007; Guareschi, 2008).

Nesse enredo, o ingresso no Instituto de Psicologia da Universidade de São Paulo, em especial no Departamento de Psicologia Social e do Trabalho, marcou o início de uma história de muitos encontros, as quais compuseram um caminho substancialmente diferente daquele imaginado nos tempos da atuação profissional no Sistema Socioeducativo. Entretanto, neste lugar a qual tivemos a honra de partilhar diversas visões de mundo, talvez o aprendizado mais importante para qualquer conhecimento, ainda que parcial, acerca a realidade da adolescência em conflito com a Lei, tenha sido a compreensão da complexidade que envolve o fenômeno em todas as suas nuances e recortes.

Por complexidade, aqui me refiro a uma dinâmica que é composta por diversas técnicas e atores, as quais se afirmam através de suas narrativas, em cada nova subjetividade sob a qual intervém no cotidiano da Justiça Juvenil, ao mesmo tempo que atualizam ou reconstróem os diagramas de poder a qual se inscrevem a lógica institucional do Sistema, (Cafangi, 2011). Isto posto retomo minhas questões iniciais de pesquisa a fim de confirma-las ou refutá-las sob o crivo dos resultados de campo. A coexistência de perspectivas diversas sobre responsabilização na justiça Juvenil em nosso campo mostrou-se verdadeira, ainda que parcial, pois estas revelam algo mais que condutas derivadas dos dois grandes campos Doutrinários descritos na literatura, a saber, o garantismo e a Doutrina menorista.

Neste sentido, outro ponto referente a nossa questão inicial considerava categorias decisórias nas Varas de apuração a qual reeditassem categorias já observadas por pesquisadores em outros períodos ou outros contextos, e esta também se mostrou parcialmente verídica, pois em nossa análise dos conteúdos das narrativas, constatamos as seguintes categorias: Estado democrático 
de Direito, Tutelar-correcional, Tutelar garantista e o diálogo estabelecido a partir destes apontamentos nos possibilitou perceber a lógica inerente que se repete nas Práticas Jurídicas junto a determinados estratos sociais e étnicos, vigilância que se inicia desde as táticas policiais de exceção nas periferias (Wacquant, 2001; Batista, 2010).

Ao mesmo tempo, demarcou aspectos locais da intersecção juventude e criminalidade, agregando o importantíssimo marcador da questão do tráfico de drogas na questão da Socioeducação. Pudemos verificar a existencia e a persistencia de muitos pontos já apontados na extensa discussão sobre o proibicionismo nas ultimas décadas, entretanto, a peculiaridade de sua posição na Justiça da Infancia, em especial na possibilidade de desvelar nessas narrativas a engrenagem de extermínio que Poder público e Organizações criminosas transnacionais constituem para os meninos trabalhadores no varejo do tráfico. Tal qual se apresenta consensual na literatura o fracasso da política de drogas e a abordagem da Segurança Pública para enfrentamento da questão, a realidade da adolescência e juventude também aponta para uma urgente necessidade de se reconhecer as violações que o tráfico representa para estes meninos. Uma transformação que discuta novos modelos de legislações sobre substancias entorpecentes sem que para isso abra mão do Paradigma da Proteção Integral no processo.

Esta anistia, tal qual esboços já desenvolvidos em outros países latino americanos, também assolados pelos impactos do proibicionismo consiste num tema indissociável da temática juventude e vulnerabilidade, junto com as políticas de segurança e a ação policial nas cidades. Quando o dispositivo policial de controle de populações periféricas é acionado, se torna invisível qualquer discurso que busque contrádize-lo e, como restou comprovado em nossa pesquisa, no caso das infrações cometidas no varejo das drogas, a atribuição de culpa é extensiva à condutas anteriores praticadas pelo adolescente. Esta fora apenas uma das muitas violações na qual o aparato policial é protagonista. A tradição de uma cultura autoritária remete a nossa história escravocrata e, mais recentemente, há duas décadas de ditadura e forte repressão, a qual permanece criminalizando a pobreza sob o manto da guerra às drogas (Fiore, 2017; Malvasi, 2011; Wacquant, 2001).

Por isso entendemos que, nesta intersecção que se estabelece nas Varas de Apuração da Infância e Juventude, entre um Estado Penal e um Garantismo de Bem Estar Social reside a possibilidade de romper com a "Ditadura sobre os pobres que o neoliberalismo vem disseminar 
nas periferias paulistas”(Wacquant, 2001, p.10). Reconhecemos que restaram em nossa pesquisa perguntas abertas as quais não encontramos solução, tais como uma definição mais precisa da cartografia das posições ideológicas que se materializam nas praticas da Socioeducação. Uma compreensão mais apurada da dinâmica do Fórum, enquanto espaço da Justiça atravessado pela égide neoliberal de um Estado Penal, a qual desmonta seu Estado de Bem Estar incompleto em nome de uma racionalidade econômica. Se a judicialização, a intervenção direta dos Magistrados na garantia de direitos as quais o Poder Público vêm continuamente se eximindo, e é a causa maior da crescente criminalidade que observamos nas grandes cidades, é a solução para uma atuação que implemente efetivamente a Proteção Integral, também é uma resposta a qual deixaremos para a continuidade e futuras problematizações.

Mas o que podemos afirmar é que, tal qual postulado por Foucault (2001) acerca da relação Polícia e Justiça, estrutural de uma racionalidade de Estado em que a repressão e a violência fomentam uma guerra que não demonstra ter fim, porque insitem em tornar suas origens e sua aparência invisíveis. Nesta perspectiva, se indicamos uma outra racionalidade econômica que não abra mão da proteção social, garantindo condições para que a criminalidade organizada não seja o Estado na vida de muitos jovens, também afirmamos a necessidade de se articular ações em que a brutalidade e a violência sejam a única opção para uma atuação policial, e para isto se faz necessário refazer a formação dos agentes, discutir amplamente a necessidade de uma força militar nas cidades e para isto, o Poder Judiciário e sua atuação interdisciplinar na resolução de conflitos representa uma via catalisadora de processos de transformação. Por isto, esperamos que este estudo possa contribuir para retirar da invisibilidade violadora de direitos as muitas vidas que buscamos representar em nossas 12 histórias apresentadas nesta tese, que denuncie as estruturas punitivas que buscam se reatualizar nas brechas da legislação, mas que fundamentalmente, proponha o reestabelecimento do diálogo com a Justiça não do lugar inferior do réu, para a cadeira superior do Juiz, mas do espírito que moveu homens e mulheres, movimentos sociais de base e operadores do direito na utopia da construção de um Estado Brasileiro que proteja integralmente suas crianças, adolescentes e jovens. 


\section{Referências bibliográficas}

Adorno, R. C. F. Juventudes, periferias e fragmentação. (2008). Juventude e Raça; BIS - Boletim do Instituto de Saúde. Secretaria de Estado da Saúde de São Paulo; São Paulo.

Aguinsky, B. G. \& Capitão, L. (2008). Violência e socioeducação: uma interpelação ética $a$ partir de contribuições da Justiça Restaurativa. Ensaio: Revista Katalysis; v. 11, $\mathrm{n}^{\circ} 02$. Florianópolis.

Alvarez, M. C., Fraga, P. C. P. \& Campos, M. S. (2017) Apresentação: Perspectivas atuais sobre políticas, produção, comércio e uso de drogas. Dossiê Drogas e Sociedade: Uma perspectiva comparada. Revista Tempo Social. vol. 29, nº 2. São Paulo.

Araujo, F. H. M., Neto, L.F.S. \& Albino, P. L. (2012). Breve análise do Sistema macropolítico criado pela Lei 12.594/12. Revista do Ministério Público do estado de São Paulo. São Paulo.

Abramovay, M. et al (2010). Violências nas escolas. UNESCO Brasil, REDE PITÁGORAS, Coordenação DST/AIDS do Ministério da Saúde; Direitos Humanos do Ministério da Justiça, CNPq, Instituto Ayrton Senna, UNAIDS, Banco Mundial, USAID, Fundação Ford, CONSED, UNDIME: Brasília.

Batista, V. M. (1998) Difíceis ganhos fáceis. Editora Revan. $2^{\circ}$ Edição, Rio de Janeiro.

BATISTA, C. Martins. Por que as pessoas usam drogas? Disponível em http://www2.brasilrotario.com.br/revista/materias/rev935/e935_p24.html Acesso em: 12 de agosto de 2017.

Boiteaux, L. (2006). Controle penal sobre as drogas ilícitas: O impacto do proibicionismo no sistema penal e na sociedade. (Tese de Doutorado). Programa de Pós graduação em Direito Penal, Faculdade de Direito; Universidade de São Paulo.

Borghi, A. P. (2012). A justiça restaurativa e o Direito Penal Juvenil a partir de reflexões do Direito em Michel Foucault. (Dissertação de Mestrado). Programa de Pós graduação em Direito, Pontifície Universidade Católica, São Paulo. 
Costa, F. C., Penso, M. A., Sudbrack,M. F. O. \& Jacobina, O. M. P. (2011). Adolescente em conflito com a lei: o relatório psicossocial como ferramenta para promoção do desenvolvimento. Psicologia em Estudo. Vol.16(3), p.379-401.

Cotta, F. A. (2005). A crise da modernidade e a insegurança social. Artigo on line. Jus Navigandi. Disponível em: http://jus.com.br/artigos/7461/a-crise-da-modernidade-e-a-insegurancasocial/1 acessado em 12/01/2014

Delmanto, Celso. (1982). Tóxicos. Editora Saraiva, $1^{\circ}$ Edição. São Paulo.

Dieter, M. S. (2012) Política criminal aturial: A criminologia do fim da história. Tese de doutorado. Faculdade de Direito; Universidade Federal do Paraná. Curitiba.

Fiore, M. (2017). O lugar do Estado na questão das drogas: O paradigma proibicionista e as alternativas. Revista Novos Estudos - CEBRAP. nº 92. São Paulo.

Foucault, M. (2004). O Nascimento da clínica. $6^{0}$ Ed. - Forense universitária, Rio de Janeiro. . (2006). Segurança, território, população: curso no Collège de France (1978). São Paulo: Martins Fontes.

. (2007). Vigiar e punir. Nascimento da prisão. Tradução de Raquel Ramalhete. Petrópolis, Vozes.

. (2011). Ditos e escritos: Segurança, Penalidade e Prisão. Organizador Manoel Barros da Motta. RJ. Forense Universitária.

Furlan, L. F. \& Mastellini, S. (2016). A redução da maioridade penal e a realidade não enfrentada. Colloquium Humanarum. Vol. 13; N¹. Presidente Prudente, UNOESTE.

Gobbo, E.,\& Muller, C. M. (2011). A prática pedagógica na Socioeducação. Revista Emancipação., V. 11 i2, Curitiba. 
Guirado, M. A. (2010). Análise institucional do discurso como analítica da subjetividade. Prefácio de Dominique Mangueneau: Editora Annablume. São Paulo.

Jesus, M. G. M. (2016). 'O que está no mundo não está nos autos’: a construção da verdade jurídica nos processos criminais de tráfico de drogas. Tese de Doutorado. Faculdade de Filosofia, Letras e Ciências Humanas. Universidade de São Paulo.

Jimenez, L. \& Frasseto, F. A. (2015). Face da Morte: A lei em conflito com o adolescente. Revista Psicologia \& Sociedade, v. 27, nº 2. Belo Horizonte.

Maraschin, C.,\& Raniére, E. (2011). Socioeducação e identidade: onde se utiliza Foucault e Varela para pensar o Sinase. Ensaio, Revista Katalysis.

Malvasi, P. A. (2013). Interfaces da Vida Loka: Um estudo sobre jovens, tráfico de drogas e violência em São Paulo. (Tese de Doutorado). Biblioteca da Faculdade de Saúde Pública da Universidade de São Paulo, São Paulo.

Menicucci, C. G. \& Carneiro, C. B. L. (2011). Entre monstros e vítimas: a coerção e a socialização no sistema socioeducativo de Minas Gerais. Revista Serviço Social \& Sociedade, N¹07. Belo Horizonte.

Minayo, M. C. S. (2012). Análise qualitativa: teoria, passos e fidedignidade. Revista Eletrônica Ciência e Saúde Coletiva. Vol. $17 \mathrm{~N}^{\circ}$ 3, Rio de Janeiro. Recuperado de http://www.scielo.br/scielo.php?script=sci_arttext\&pid=S1413-81232012000300007

Miraglia, P. Aprendendo a lição: Uma etnografia das Varas Especiais da Infância e Juventude. Revistas Novos Estudos. n ${ }^{\circ}$ 72. São Paulo.

Monte. F.F.C.,\& Sampaio, L. C. (2008). Adolescentes autores de atos infracionais: psicologia moral e legislação. Revista Psicologia e sociedade. 
Oliveira, L.L. A criminalização da pobreza na América Latina como estratégia de controle político. Sistema Penal \& Violência, Porto Alegre. v.8, n.2, 2016.

Pereira, P. E.”Aí tá me tirando!” O que dizem jovens pobres de São Carlos sobre sí mesmo e a temática das drogas. Dissertação de Mestrado. Programa de Pós Graduação em Terapia Ocupacional. Universidade Federal de São Carlos, 2012.

Pereira, T. S. Direito da Criança e do adolescente - Uma proposta Interdisciplinar. $2^{\circ}$ ed. Rio de janeiro: Renovar, 2008. p. 109.

Rosa, M. D, \& Vincentin, M. C. Os Intrátaveis: o exílio do adolescente do laço social pela noção de periculosidade e irrecuperabilidade. Revista de Psicologia Política, 2010, Vol. 10(19), p. 107124.

Sartório, A. T.,\& Rosa, E. M. (2010). Novos paradigmas e velhos discursos: analisando processos de adolescentes em conflito com a lei. Serviço Social \& Sociedade, 2010, n.103 , p 554-575.

Silva, M. L. O. (2010). Violência e controle sócio-penal contra adolescentes com práticas infracionais. Revista Serviço Social \& Saúde. UNICAMP Campinas, v. IX, n.9, Jul. 2010.

Silva, R. Ciencia da delinquência: o olhar da USP sobre o ato infracional, o infrator, as medidas socioeducativas e suas instituições. (2013). In Seminário de encerramento do Curso de atualização teoria e Prática do estatuto da criança e do Adolescente: ênfase nas medidas socioeducativas. Programa de iniciação científica da Universidade de São Paulo. São Paulo.

Vincentin, M.C.G. (2004). A VIDA EM REBELIÃO: Jovens em conflito com a lei. São Paulo, SP: Hucitec: Fapesp. 
Vilhena, J., Zamora, M. H. R. N,\& ROSA, C. M. Da Lei dos Homens à Lei da Selva. Sobre adolescentes em conflito com a lei. Artigos temáticos. Revista Trivium - Estudos Interdisciplinares Arte \& Psicanálise. Ano III, Edição II, 2011.

Zaluar, Alba (Organizadora); Henman, A.; Paixão, A.L; Musumeci, B.; Sá, B.S.; MacRae, E.

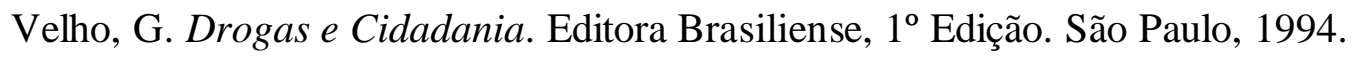




\section{Anexos}

\section{$1^{\circ}$ Coleta de dados:11/04/2016}

Data de Nascimento: 07/05/2000

Nome Fictício: João I

Numero processo: 0015200-80.2015

Data do processo: 07/08/2015

Ato infracional: Tráfico

\section{Representação}

Consta do incluso expediente que, nesta cidade e comarca, o adolescente João I, trazia consigo e mantinha em depósito, para entrega de qualquer forma, a consumo de terceiros, substâncias entorpecentes e causadoras de dependência física e psíquica, agindo assim sem autorização e em desacordo com determinação legal ou regulamentar (...)

Segundo se apurou, os policiais militares foram informados por populares da ocorrência de traficância na região do fato. Avistaram o adolescente e outro jovem e decidiram aborda-lo, os adolescentes empreenderam fuga. Após breve perseguição, o adolescente e outro jovem foram abordados e, com eles encontrado a substância ilícita. O adolescente em tela trazia consigo para fins de tráfico, 71 invólucros contendo cocaína, conforme laudo de constatação incluso (...)

Ouvidos nos termos do Artigo 179 do ECA, ambos confessaram a traficância (...) 


\section{Decisão}

Considerando (...) a prática infracional admitida, a sincera disposição em não mais infracionar e a menor potencialidade ofensiva da conduta (...)

A medida consensualmente proposta: liberdade assistida pelo prazo necessário à ressocialização, cujos objetivos são: Escolarização; Profissionalização e documentação (...)

\section{Relatório Serviço de Medida socioeducativa em meio aberto \\ (PIA- Plano individual de atendimento)}

O núcleo familiar de João I é composto pelo padrasto e pela genitora, a qual trabalha com reciclagem.

João I iniciou os estudos na idade prevista, mas teve problemas de adaptação/indisciplina na escola e interrompeu a vida escolar antes da $4^{\circ}$ série do Ensino Fundamental. Segundo relato do adolescente, sua genitora então o tirou da escola após estes episódios.

Em entrevista individual para construção deste PIA, o adolescente relatou que queria ter voltado a estudar, mas ninguém fez sua matrícula (...) Ainda segundo o adolescente, sua mãe dizia que o adolescente é inútil (...)

Na família, ninguém é alfabetizado. João I mal consegue escrever.

(no processo de retomada da escolarização, após cadastro na rede de ensino, Marcos foi encaminhado para um Cieja há cerca de 5,2 km de sua casa)

A região onde residem é extremamente vulnerável (...) onde o tráfico domina; O endereço relatado pelo adolescente e sua genitora se trata de área de ocupação. 
O pai biológico de João I mora próximo à residência da genitora e trata o filho muito mal segundo a mesma (...) Quanto a motivação para o ato delituoso, Marcos contou que realizou o ato infracional para (ter dinheiro para) ir a uma lan house. 


\section{$2^{\circ}$ Coleta de dados: 02/05/2016}

Data de Nascimento:07/09/1999

Nome Fictício: João II

Número processo:0016658-35.2015.8.26.2015

Data do processo: 20/08/2015 (apreensão)

Ato infracional: Tráfico

\section{Audiência de apresentação}

(...) João II, foi apreendido por policiais civis que avistaram um indivíduo em atitude suspeita, quando realizavam patrulhamento pelo local dos fatos. Após revista, identificaram João II na posse de substância entorpecente, causadora de dependência física e psíquica (...)

O adolescente já cumpria medida socioeducativa de semiliberdade por ato infracional cometido anteriormente.

(...) Não possui respaldo familiar adequado para frear seus freios inibitórios. Na oitiva junto ao Ministério Público, negou a autoria do ato infracional.

(...) Indagado o adolescente, este manifestou o desejo de não recorrer da presente sentença.

Trata-se de fato grave, praticado em circunstâncias que denotam a impossibilidade, por ora, de o mesmo permanecer no convívio social.

Frisa-se que o adolescente é reincidente.

Estão presentes indícios de autoria e materialidade, o que não sustenta a versão do adolescente de que, fora incriminado e, na ocasião dos fatos, não praticava a traficância, ainda que em outros momentos admite já o ter feito (...). 
O tráfico de entorpecente coloca em risco a ordem pública, estando autorizada a internação provisória (...)

Faço consignar que o presente delito é o grande mal da sociedade contemporanea, atingindo de forma difusa um número inimáginavel de pessoas e famílias, além de estar associado, na maioria dos casos, à criminalidade organizada. Equiparado a delitos hediondos por Lei Federal editada pelo legislador é, por consequência, insuscetível de fiança e liberdade provisória em que pese a ausência de violência ou grave ameaça. Atualmente, a nova lei de tóxicos classifica como hediondo o crime de tráfico de entorpecentes (...) Não obstante os Institutos do Direito penal e processual penal não guardarem relação matemática e linear com aqueles da justiça menorista, forçoso o reconhecimento da vontade do legislador e da sociedade que representa, ao editar a tal lei de crimes hediondos, no sentido ao endurecimento a este tipo de delito.

Sendo que o desprezo pelo julgador, seja sob qual pretexto for, atenta não só contra a lei em sí, mas principalmente contra o Estado Democrático de Direito que jurou defender.

A custódia provisória autorizada pelo artigo 108 do ECA, constitui medida cautelar que não se vincula necessariamente às hipóteses do artigo 122 do mesmo Estatuto, dependendo apenas da constatação de sua necessidade imperiosa, como ocorre na espécie, em que se busca resguardar também, além da ordem pública, a própria segurança do infrator, o qual deve ser imediatamente afastado dos apelos criminógenos do meio. 


\section{Relatório polidimensional Fundação CASA}

João II apresenta atraso na escolarização. Foi reprovado por faltas, devido a falta de estimulação, uma vez que não pareceu-nos ter dificuldade nos conteúdos escolares referentes a sua idade escolar (...)

A mãe do adolescente compareceu à entrevista para elaboração do Plano de atendimento individual da medida de internação mostrando dificuldade de atenção (...) 


\section{$2^{\circ}$ Coleta de dados: 02/05/2016}

Data de Nascimento: 19/06/1997

Nome Fictício: João III

Número processo:0016704-24.2015.8.26.2015

Data do processo:

Ato infracional: Tráfico

\section{Audiência de apresentação (trechos)}

Os policiais ouvidos disseram que a droga estava em poder do indiciado, em ponto de vendas de drogas (...)

Vale dizer da tese recorrente trazida pela defesa que o depoimento dos agentes da lei têm menos valor. O valor dos depoimentos dos policiais militares é o mesmo que o de outras testemunhas $(\ldots)$

Sentença: o jovem não estudava e trabalhava com familiar, sem formalização (...) a família não foi capaz de conte-lo(...)

Têm razão a promotora ao destacar a quantidade expressiva de drogas apreendidas, indicando escala na comercialização e largo envolvimento com o crime organizado 


\section{Relatório Diagnóstico polidimensional - Fundação CASA}

O adolescente João III relata estar na traficância há algum tempo e o faz de forma eventual, que com o lucro, comprou um carro e precisa manter o veículo.

(...) Não tece crítica ao desvalor da conduta, mesmo tendo perdido um irmão de 16 anos, vítima de overdose. Verbaliza que no momento da apreensão não viu ninguém comprando drogas. 


\section{$3^{\circ}$ Coleta de dados 11/05/2016}

Data de Nascimento: 09/11/1998

Nome Fictício: João IV

Número processo: 0018551-61.2015.8.26.0015

Data do processo: 16/09/2015 (Data do fato)

Ato infracional:Tráfico

\section{Representação}

Consta do Boletim de Ocorrência incluso nos autos que, no dia 16/09/2015, neste município e comarca, o representado trouxe consigo, guardou e expôs à venda, sem autorização e em desacordo com legislação complementar, com a finalidade de entrega a terceiros (tráfico), substâncias entorpecentes que causam dependência física e psíquica. Apurou-se que o representado foi abordado por policiais militares no local, conhecido ponto de venda de drogas. (...)

Indagado sobre a prática do tráfico de drogas, João IV confessou informalmente aos milicianos a prática da traficância.

Assim, com fundamento nos artigos 180, inciso III e, artigo 201 inciso II, ambos da Lei 8069/90 Represento a V. Excelência os adolescentes supramencionados, pretendendo a aplicação da medida socioeducativa prevista no artigo 112 do ECA, e requeiro a instauração do devido procedimento legal, previsto no artigo 184 e seguintes, também do mesmo Estatuto.

Destarte, é preciso requerer a decretação da internação provisória do adolescente. Trata-se de fato grave, praticado em circunstâncias que denotam a impossibilidade, por ora, dos menores permanecerem no convívio social. 
Frisa-se que o adolescente conta com passagem pela $4^{\circ} \mathrm{VEIJ}$ por posse de drogas. (negrito do promotor).

\section{Audiência de apresentação}

(... ) Defensoria: É primário, estuda e esta inserido em núcleo familiar, contando com respaldo familiar. Reside em endereço fixo(...)

Nos termos do artigo 122, o caso não se enquadra em nenhuma das hipóteses legais para imposição de medida de internação. A custódia cautelar mostra-se desproporcional e será violado o princípio da homogeneidade (a medida cautelar é mais gravosa que o resultado final possível para a demanda).

Sentença (juiz):(...) A despeito de primário, o adolescente não apresentou arrependimento e demonstrou vulnerabilidade ao meio social (...) Não possui amparo familiar, residindo com a irmã de apenas 19 anos, sendo que os pais moram no exterior; Não comprovou frequencia em estabelecimento de ensino, por fim a internação é de rigor.

A autoria também restou comprovada pela prova oral (Boletim de Ocorrência) constante dos autos, senão vejamos. Ouvido em juízo, o adolescente negou a prática do ato infracional. No entanto a prova testemunhal (as testemunhas são os policiais que realizaram a abordagem) confirmou a ocorrência do ato infracional (...)

Com efeito, as testemunhas ouvidas apresentaram relato com riqueza de detalhes quanto à caracterização do ato infracional. O policial reconheceu o adolescente; disse que havia denuncia com ordem de serviço para a viatura permanecer no local dos fatos. Ali o adolescente foi abordado com outros indivíduos; Somente João IV estava com drogas. 
(...) A versão apresentada pelo adolescente não prospera e não autoriza a improcedência da pretensão ministerial, que sugere a medida de internação para o adolescente, porque além de pouco crível e contraditória, não encontra respaldo em nenhum elemento de informação ou prova produzida.

Como cediço, os policiais militares são agentes públicos e, por isso, os seus relatos são dignos de credibilidade, constituindo, quando seguros e coerentes, importante meio de prova.

(A defesa do adolescente questionou o testemunho dos policiais em seu depoimento, alegando que eles participaram da apreensão e, deste modo, não poderiam ofertar um testemunho com a isenção necessária para o devido processo legal)

Dessa forma, até prova cabal em contrário, no caso, não produzida, deve-se ter por certo que falaram a verdade, quando ouvidos em juízo. Logo, inexistindo nos autos qualquer elemento de informação, sequer indiciário, de que as testemunhas pretendessem responsabilizar injustamente o adolescente não acolho a tese da defesa, baseada no relato do adolescente de que os policiais forjaram sua apreensão na modalidade de tráfico (...)

Ressalte-se que o adolescente já permaneceu internado provisoriamente por 33 dias, período no qual a medida lhe impactou.

\section{Relatório polidimensional Fundação CASA}

(trechos da avaliação da profissional em serviço social) 
Declara que o ambiente familiar é harmonioso. Reside com a irmã Nair IV, estudante de arquitetura; a tia do adolescente mora na casa da frente (...).

João IV nega seu envolvimento na traficância. Refere que estava no local para adquirir drogas para consumo quando foi abordado pela polícia. Estudou até o $2^{\circ}$ ano do Ensino médio. A interação familiar é descrita como satisfatória, existindo diálogos e respeito mútuos, entretanto a dinâmica familiar permite a João IV ter uma liberdade exacerbada, levando em consideração que, em alguns momentos do ano, fica somente a irmã Nair IV.

Na configuração da vida social e comunitária João IV passou a interagir com pessoas e ambientes inadequados (...)

\section{Relatório Serviço de Medida socioeducativa em meio aberto (PIA- Plano individual de atendimento)}

O adolescente relata que fora jogar bola quando foi abordado pela polícia, pois haviam recebido denuncia de tráfico (...) o adolescente disse que não estava com drogas, mas foi colocado dentro da viatura e no interior do automóvel, os policiais lhe mostraram um saco contendo cocaína/maconha e disseram "olha o que encontramos com você”(... ) 


\section{$4^{\circ}$ Coleta de dados 15/06/2016}

Data de Nascimento: 10/09/1999

Nome Fictício:João V

Número processo:

Data do processo: $15 / 10 / 2015$

Ato infracional: Tráfico de drogas e condutas afins

\section{Representação}

Consta do incluso que expediente que, no dia 25 de agosto de 2015, por volta das 15h40, na Avenida X, altura do $\mathrm{N}^{\mathrm{o}} \mathrm{Y}$, nesta cidade e comarca, o adolescente João V trazia consigo, para consumo de terceiros, substancias entorpecentes causadoras de dependência psico e físicoquímica, sem autorização e em desacordo com determinação legal e regulamentar, conforme auto de constatação em anexo, e laudo químico-toxicológico a ser oportunamente juntado nos autos.

Segundo se apurou, policiais militares foram informados de que no local dos fatos estaria ocorrendo o tráfico de entorpecentes assim, para lá se dirigiram. Chegando ao lugar supramencionado, avistaram o adolescente em atitude suspeita e resolveram abordá-lo. Na ocasião, o menor João V tentou empreender fuga, mas acabou sendo apreendido. Em revista pessoal, foram encontrados, no bolso direito de sua bermuda, 43 supositórios de cocaína (sic), enquanto no bolso esquerdo foi encontrada a quantia de R 51 reais em dinheiro.

Indagado pelos policiais, o representado confessou o comércio de drogas.

O laudo de constatação detectou positivo para cocaína nas substâncias apreendidas.

As circunstâncias da apreensão, a quantidade e a forma de acondicionamento das drogas não deixam dúvidas sobre a destinação comercial das mesmas. 
Trata-se desta feita, em tese, da prática da prática do ato infracional previsto no Art. 33 “caput”, da Lei 11.343/2006.

O adolescente, ouvido nos termos do Art. 179 do ECA, confessou a prática do ato infracional. Presentes a genitora e o advogado (constituído pela família) do adolescente.

Assim, com fundamento nos artigos 180, inciso III e 201, inciso II, ambos da Lei 8.069/90, Represento a V. Ex ${ }^{\mathrm{a}}$ o adolescente supramencionado pretendendo a aplicação de medida socioeducativa prevista no artigo 112 do já citado diploma legal e requeiro a instauração da do devido procedimento legal, previsto no artigo 184 e seguintes, também do mesmo estatuto.

Destarte, é preciso requerer a decretação da internação provisória do adolescente. Tratase de fato grave, praticado em circunstancias que denotam a impossibilidade, por ora, de o mesmo permanecer no convívio social.

Requeiro que se oficie ao D.P de origem para que encaminha o laudo de exame químicotoxicológico das substâncias apreendidas.

Rol (Testemunhas):. Policial Militar 1.

Policial Militar 2. 


\section{Audiência de apresentação}

(O juiz inicia sua fala retomando a representação/acusação do Ministério Público e as objeções da defensoria)

(... ) Posto isto, decreto a internação provisória do adolescente, haja visto que se trata de ato infracional grave (...)

O adolescente responde a outros dois processos em trâmite, não se apresentou e vinha obstando a instrução processual (...)

...Ademais, o tráfico de entorpecentes coloca em risco a ordem pública, estando autorizada a internação provisória, nos termos do Art. 174 do ECA...

...Faço consignar que o presente delito é o grande mal da sociedade contemporânea atingindo de forma difusa um número inimaginável de pessoas além de estar associado, na maioria dos casos à criminalidade organizada...

\section{Relatório serviço de Medida socioeducativa em meio aberto Plano individual de Atendimento PIA}

Informamos que o adolescente João $\mathrm{V}$ compareceu neste serviço de medida socioeducativa em meio aberto para dar início ao cumprimento da medida de Liberdade Assistida, cumulada com Prestação de Serviços à Comunidade. Nesta data, acolhemos e orientamos o adolescente e sua genitora, $\mathrm{Sr}^{\mathrm{a}}$ Maria $\mathrm{V}$ quanto ao cumprimento da medida, bem como preenchemos o plano individual de atendimento PIA conforme SINASE, e estabelecemos as metas que serão desenvolvidas no decorrer do acompanhamento socioeducativo. 
As informações deste relatório são baseadas no relato do adolescente e da genitora obtidos em 2 atendimentos.

- Histórico familiar:

O adolescente reside com a genitora, o padrasto e dois irmãos, em uma residência própria que possui pavimentação, energia elétrica e saneamento básico, com a seguinte composição familiar:

- João V, adolescente, 16 anos de idade, Ensino Fundamental Incompleto, não exerce atividade laborativa;

- Maria V, genitora, 47 anos, ensino Fundamental incompleto, trabalha como diarista, renda mensal de aproximadamente $\mathrm{R} \$ 750$.

- José V, padrasto, 47 anos, Ensino Fundamental incompleto, desempregado.

- Jacó V, irmão, 13 anos, cursando a $6^{\circ}$ série do Ensino Fundamental.

- Tiago V, irmão 3 anos, cursando a Educação infantil.

A convivência familiar é dita como tranquila entre os membros da família. O adolescente não tem contato com o genitor, o conhece, porém não há contato. A família não é contemplada por Programa de Transferência de renda PTR e relata que já procurou o CRAS, assim foi orientada a um novo contato com o CRAS da região, a fim de verificar a possibilidade de benefícios.

A genitora relata que o genitor não registrou o adolescente, porém ela pretende procurar a justiça para reconhecimento de paternidade. Houve um acordo entre a genitora do adolescente e a avó paterna do mesmo, de que o genitor contribuiria com um valor de R\$100 mensais, e o acordo têm sido cumprido. 


\section{Metas estabelecidas em conjunto com o jovem e a família - Futuros encaminhamentos}

Comparecer assiduamente aos atendimentos individuais e grupos de adolescentes. João IV esta ciente que necessita comparecer semanalmente nos atendimentos, tanto nos grupos de adolescentes, como nos individuais, realizados neste serviço.

Retorno a Rede Escolar: a genitora esta providenciando a matrícula, para reinserção do adolescente na rede de ensino.

Objetivos declarados pelo adolescente: Encerrar a medida. 


\section{Relatório Polidimensional Fundação CASA -Inicial}

O parecer técnico respalda-se em apenas 2 atendimentos, sendo um em conjunto com a genitora e com João V e outro somente com o adolescente.

O adolescente demonstra interesse na continuidade da construção de um projeto que tenha o objetivo de encerramento da medida, além de criar uma nova perspectiva em relação ao futuro. É receptivo quanto às orientações técnicas, nesse primeiro momento.

A equipe técnica dará continuidade aos atendimentos visando o desenvolvimento das potencialidades do adolescente, além do fortalecimento de vínculos a fim de identificar outras demandas que possam emergir.

\section{Relatório Polidimensional Fundação CASA - Acompanhamento}

A dinâmica do local onde João $\mathrm{V}$ reside com a família, favorece constantemente o envolvimento do adolescente em atividades ilícitas. Considerando que o local apresenta elevada taxa de vulnerabilidade social, a alternativa de ganho fácil de dinheiro, trava uma luta desigual com outras possibilidades de não envolvimento com a ilegalidade.

João V aos 16 anos é integrante de uma cultura que opta pela aceitação através do ter, do que se apresenta de bem material, para ser aceito na comunidade do qual faz parte. Sabemos que a adolescência é um momento de construção da identidade em que a aceitação pelo grupo tornase fundamental.

Dessa maneira, o adolescente supracitado, tem optado pela aceitação da comunidade, valorizando a presença com amigos e os momentos de descontração, de maneira que tem deixado para trás as responsabilidades que o ato infracional lhe acarretou, e as possibilidades de investir em si, visando obter melhores oportunidades a longo prazo. 
Será neste sentido que a equipe técnica continuará trabalhando, realizará uma sensibilização que proporcione ao adolescente ter clareza das consequências de não implicar-se com a medida socioeducativa, além disso com as barreiras que podem ser lhe impostas em decorrência da interrupção das atividades escolares. 


\section{$4^{\circ}$ Coleta de dados 15/06/2016}

Data de Nascimento: 13/09/1998

Nome Fictício: João VI

Número processo:

Data do processo: 17/07/2015

Ato infracional: Tráfico de drogas e condutas afins

\section{Audiência de apresentação}

(...)Trata-se de ato infracional extremamente grave, equiparado a crime hediondo previsto na Lei 11.343/2006 (...) o que autoriza a internação provisória... a fim de resguardar a segurança do adolescente João VI, que deve ser imediatamente afastado das causas que ensejaram a conduta inadequada (...)

Conforme relato dos policiais, que até prova em contrário, merece total credibilidade, vislumbro necessária a custódia cautelar para garantia da ordem pública, conveniência da instrução bem como, para segurança do próprio representado.

\section{Relatório polidimensional Fundação CASA (Trechos área psicológica)}

(...) $\mathrm{O}$ genitor faleceu antes de seu nascimento. Estudou até o $6^{\circ}$ ano do Ensino Fundamental; Apresenta dificuldades em ler e escrever. 
(...) Observamos em nossos atendimentos que este jovem deixou os estudos em segundo plano, também para exercer trabalhos esporádicos para auxiliar no orçamento doméstico. Observamos também que João VI apresenta valores invertidos (...)

Assistente Social; (...) Informamos que o educando recorre as "facilidades"que a criminalidade lhe proporciona para suprir seus desejos e vontades mais simples. 


\section{$5^{\circ}$ Coleta de dados 04/07/2016}

Data de Nascimento: 15/03/1998

Nome Fictício: João VII

Número processo:

Data do processo: $17 / 09 / 2015$

Ato infracional: Tráfico de drogas e condutas afins

\section{Representação (01/08/2015)}

Consta do Boletim de Ocorrência incluso que no dia 31/07/2015 num distrito da Zona norte da capital paulista, o adolescente João VII e o imputável Moisés VII, previamente associados, traziam consigo drogas, para fins de entrega a consumo de terceiros (...)

(...) Apurou-se que os policiais civis, em diligência pelo local dos fatos, avistaram João VII e o maior Moisés VII, sendo que o adolescente trazia em uma das mãos uma bolsa e na outra segurava um rádio HT (...) os policiais afirmaram que foram recebidos a tiros logo anunciaram a abordagem, mas conseguiram reverter a situação e dominar João VII e o imputável. Segundo estes últimos, realizarão a investida por acreditar que eram indivíduos que pretendiam disputar o ponto de tráfico de drogas. (...)

As circunstâncias da apreensão, a quantidade e variedade de drogas, além de sua forma de acondicionamento (já divididas para a venda) e a localização de um rádio HT não deixam dúvida de que os entorpecentes se destinavam à narcotraficância. 
O adolescente foi ouvido informalmente, nos termos do Art. 179 do ECA e confessou a prática do ato infracional, narrando que os fatos se deram exatamente como foi descrito pelos policiais esclarecendo que somente o maior Moisés VII reagiu a abordagem.

Afirmou ainda que esta no tráfico há sete meses e que sustenta a sí e a sua companheira com o dinheiro da comercialização ilícita (...)

É preciso ainda, requerer a decretação da internação provisória do adolescente. Tratase de fato grave, praticado em circunstâncias que, por ora, denotam a impossibilidade do convívio social.

Note-se que o adolescente relatou na Fundação CASA (relatório da técnica da unidade provisória de internação a qual foi encaminhado o adolescente logo após o ato infracional $e$ antes da realização desta representação) que há sete meses alugou uma casa onde esta residindo com sua companheira. Ocorre que nenhum dos dois tem emprego (formal ou informal) para garantir o pagamento das despessa domésticas, o que autoriza a conclusão de que o adolescente vem se sustentando e a sua companheira, com dinheiro proveniente do tráfico. (...) A desestrutura social do jovem demonstra que, se for solto, sem a devida intervenção do Estado em sua estrutura familiar, ele voltará para a prática do tráfico.

\section{Audiência de Continuação}

\section{Conclusão:}

Com efeito o adolescente foi apreendido quando trazia consigo quantidade considerável de substâncias causadoras de dependência física e psíquica, conforme relato dos policiais que, até prova em contrário, merecem total credibilidade, havendo grande probabilidade de tal substância se destinar à venda e para consumo de terceiros... 
(...) Portanto deve ser indeferido o pedido de liberação formulado pela Defensoria Pública, pois o ato infracional é extremamente grave, equiparado a crime hediondo. Está, portanto autorizada a internação provisória, a fim de resguardar a ordem pública e a própria segurança do infrator, o qual deve ser imediatamente afastado das causas que ensejaram a conduta inadequada, até que o caso seja melhor apurado.

\section{Relatório polidimensional F. CASA}

Adolescente procedeu entrada neste centro em 31/07/2015 encaminhado pelo $45^{\circ}$ Delegacia de Polícia. Não consta passagem anterior por esta fundação.

O pai do adolescente é falecido, reside com a mãe e mais 4 irmãos. Interrompeu os estudos no $9^{\circ}$ série do Ensino Fundamental. Afirmou ser usuário de maconha. Informou que há sete meses alugou uma casa com um cômodo e esta residindo com a companheira Maria VII, 19 anos.

Não possui renda para garantir a manutenção das despesas domésticas, ambos estão desempregados(...)

\section{Relatório Polidimensional diagnóstico Fundação CASA \\ (Área Psicológica)}


O adolescente João VII apresenta os aspectos cognitivos preservados, memória, atenção, concentração, localização no tempo e no espaço.

Denota tendência à introversão, apesar de manter bom contato verbal, mantém boa interação com os demais adolescentes e com a equipe multidisciplinar. Entretanto, no momento, apresenta a falta de direcionamento no seu repertório individual, revelando auto crítica prejudicada, a qual pode estar relacionada com as experiências de vida até o momento.

A trajetória de vida do adolescente revela ter sido permeada por dificuldades desde a mais tenra idade, há indicativos de que a genitora negligenciou o seu papel materno no que se diz respeito aos cuidados básicos emocionais e afetivos.

O adolescente percebe a figura materna como distanciada afetivamente, embora não denote cultivar sentimentos de raiva por sua mãe, foi possível perceber que existe ressentimento em relação a ela, como por exemplo, a mágoa de não se sentir amado, e se coloca numa posição em relação a sua genitora, como sabedor de que não poderá contar com o apoio dela.

A princípio, o adolescente revela nas suas atitudes e no seu comportamento significativa tristeza, o que significa estar em grande parte relacionado sobretudo, com suas carências afetivas, assim como da ausência de figuras parentais, que pudessem lhe direcionar.

Não revela agressividade e rebeldia propriamente dita, todavia é possível que se envolva em delitos para manter sua sobrevivência e também por estar inserido numa cultura que banaliza a ilicitude. Portanto sua conduta infracional parece ser muito mais que a simples falta de empatia, o que de certo não justifica nenhuma conduta inadequada ou ilícita de sua parte, mas colabora de forma significativa para sua vulnerabilidade a esfera delitiva, haja vista a influencia destes fatores para a formação e desenvolvimento de uma pessoa.

O que também parece ter contribuído para o envolvimento do jovem é falta de recursos socioeconômicos, assim como a falta de acesso à cultura e lazer, e políticas públicas que realmente contemplem suas necessidades. 
Outro fator preponderante que pode ter favorecido suas ações, e te-lo marcado emocionalmente é o suicídio de seu genitor, o qual foi presenciado por ele e outros irmãos, segundo informações da irmã do adolescente, $\mathrm{Sr}^{\mathrm{a}}$ Madalena VII, a qual compareceu em entrevista psicossocial. (Segundo este relato) o genitor era usuário de drogas ilícitas e lícitas, ingeria etílicos descompassadamente. Madalena VII acredita que o envolvimento do genitor com drogas favoreceu o cometimento do suicídio por este.

Frente ao exposto, concluímos que tudo que foi vivido pelo jovem concorreu para contribuir para a situação de seu envolvimento e apreensão.

No que concerne ao ato infracional, o jovem assume, e tem dificuldades em vislumbrar uma vida diversa, de buscar alternativas; lhe falta direcionamento de responsáveis que possam lhe assegurar um desenvolvimento pleno, o que parece contribuir para a criticidade pouco aprofundada do jovem em relação aos seus comportamentos e atitudes, evidenciando a necessidade de ser sensibilizado neste sentido, objetivando sua compreensão da realidade que o cerca, assim como aprender a lidar com as adversidades de sua vida buscando outras soluções alternativas adequadas, diversas da infracional.

Necessita de intervenções profissionais que possibilitem reflexões acerca de sua própria vida, objetivos a serem construídos e suas perspectivas futuras, mas também de atendimento psicológico individualizado para melhor compreensão de sua dinâmica pessoal, das experiências traumáticas vivenciadas, dos conflitos emocionais e das carências apresentadas nesta esfera. 


\section{$5^{\circ}$ Coleta de dados 04/07/2016}

Data de Nascimento: 31/03/1997

Nome Fictício: João VIII

Número processo:

Data do processo: 28/09/2015

Ato infracional: Tráfico de drogas e condutas afins

\section{Audiência de continuação}

(...)Na audiência de apresentação, o jovem negou a prática do ato infracional. Ele e sua genitora adizirão que a apreensão fora efetuada com outro jovem que estava no mesmo local dos fatos e o policial Zaqueu VIII pediu dinheiro a ele para libera-lo. Em seguida, atribuiu a falsa acusação ao declarante. (...)

A versão apresentada (pelo adolescenteJoão VIII) é inverossímil, restou divorciada dos demais elementos coligidos e não merece ser acolhida.

A testemunha Davi VIII (policial militar que junto com Zaqueu VIII apreendeu o adolescente) afirmou conhecer o adolescente da ocorrência, até porque nenhum interesse (os policiais) teriam de acusá-lo injustamente (...)

O ato infracional, de péssima repercussão social, embora praticado sem violência ou grave ameaça é gravíssimo e equiparadao a crime hediondo na Lei penal. O adolescente ademais, já ostenta condenações por diversos atos infracionais, tudo a denotar vida bastante desregrada e sem limites, de modo que deve ser lhe aplicada a medida socioeducativa de internação como única apta a despertar-lhe o seu senso de responsabilidade e viabilizar a sua futura inserção social (...) 
Ante o exposto, julgo procedente o pedido formulado na representação, condeno o jovem João $\mathrm{V}$, qualificado nos autos, pela prática de ato infracional tipificado pelo artigo 33 da lei 11.343/2006 e aplico-lhe a medida socioeducativa de internação, pelo prazo mínimo de seis meses, prorrogável por até 3 anos, em caso de necessidade.

Oficie-se para a incineração das drogas apreendidas, preservando-se o suficiente para eventual contraprova até o trânsito em julgado, após o que o remanescente também deverá ser incinerado...

Decreto a perda do dinheiro apreendido, fruto da venda de drogas, com fulcro na lei 11.343/2006, e determino a sua reversão ao FUNAD após o trânsito em julgado.

Expeça-se o necessário ao cumprimento da medida socioeducativa.

\section{Relatório informativo SME Liberdade Assistida anterior}

(João VIII recebeu a medida Socioeducativa pelo ato infracional de furto, segundo os autos, cometido no lava-rápido em que trabalhava)

Fomos recebidos pelo padrasto de João VIII, Sr. Abrão VIII. Relatou-nos que o adolescente foi "preso" há uma semana aproximadamente, acusado de tráfico. Contudo ainda segundo relato do Sr. Abrão V, a situação que ocasionou este fato teria sido forjada (sic)

Nos informou também que, sua esposa , Sra. Esther VIII esta muito preocupada, pois é sempre o mesmo policial que "leva” João VIII para casa e que tem conhecimento que acontece a cobrança de $\mathrm{R} \$ 10.000$ para não indiciá-lo por tráfico de drogas (sic). 


\section{$6^{\circ}$ Coleta de dados 27/07/2016}

Data de Nascimento: 25/04/1999

Nome Fictício: João IX

Data do fato: 19/03/2015

Data do processo: $11 / 06 / 2015$

Ato infracional: Tráfico de drogas e condutas afins

\section{Representação}

Consta do incluso no Boletim de Ocorrência, que no dia 19/03/2015, por volta das 11h30, na Rua X, os adolescentes Marcos IX e João IX, agindo em concurso e com igualdade de propósitos, associaram-se com o fim de praticar tráfico de drogas e traziam consigo drogas, sem autorização e em desacordo com determinação legal ou regulamentar.

Apurou-se que os adolescentes encontravam-se na via pública, quando foram abordados por policiais. Em revista pessoal, com Marcos IX foi localizada a quantia de R\$120,60, oriunda do comércio ilícito, enquanto que com João IX foram localizados 29 porções de maconha, 69 pedras de crack e 25 pinos de cocaína. As drogas apreendidas totalizaram 58,5 g de maconha e 25,2g de cocaína, conforme laudo de constatação.

A confissão dos adolescentes, as circunstâncias da apreensão, a quantidade, a diversidade e a forma de acondicionamento das substâncias evidenciam que as mesmas se destinavam ao tráfico.

Trata-se, desta feita, em tese, da prática de ato infracional previsto no Art. 33 e 35 da Lei 11.343 de 2006.

Devidamente cientificados da impulsão que lhes é feita e que ora consta da representação, os adolescentes foram ouvidos informalmente, nos termos do Art. 179 do ECA, na presença do 
genitor de João IX e da tia de Marcos IX, ambos os adolescentes confessaram a prática infracional, dizendo que estão atuando no comércio ilícito há cerca de 4 meses, ganhando R \$70 por dia. Moisés esclarece que conta com passagens anteriores, já tendo recebido medida de Liberdade Assistida.

\section{(...)}

Destarte, é preciso requerer a decretação da Internação provisória dos adolescentes. Trata-se de fato grave, equiparado a hediondo na Lei Penal, o que denota a impossibilidade, por ora, de os jovens permanecerem no convívio social, conforme Art. 174, parte final do ECA. Anote-se que João IX é multirreincidente.

\section{Audiência de Apresentação}

Aos 20 de março de 2015, na sala de audiência da 2 VEIJ, sob presidência da MM. Juiz (a) de Direito, o representante do MP e a Defensoria Pública. Pela MM Juiza foi proferida a seguinte decisão: "Presente os requisitos a que alude o Art. 182 do ECA, recebo a representação ofertada pelo MP em desfavor do adolescente João IX, pela suposta prática de atos infracionais equiparados aos crimes previstos no Art. 33 e no Art. 35, ambos da Lei 11.343 de 2006.

\section{(...)}

A seguir pela Defensora pública foi dito: João IX não reitera na prática de atos infracionais graves, uma vez que foi responsabilizado somente por um ato de natureza grave. $\mathrm{O}$ ato imputado é desprovido de violência ou grave ameaça. Logo, não há previsão legal para medida de internação, o que torna a medida cautelar desproporcional e violadora do princípio da homogeneidade. Desse modo, não restou demonstrada a necessidade imperiosa da internação provisória nos termos do Art. 108, do ECA. Por fim os genitores presentes neste ato comprometerem-se a apresentar seus filhos na próxima audiência, em caso de liberação. (...) 
Por fim, pela MM. Juíza foi proferida a seguinte decisão: Vistos. 1) Ao oferecer representação, o MP pugnou pela decretação da internação provisória dos adolescentes. O pedido comporta parcial deferimento. Os elementos de informação produzidos até o momento, notadamente os testemunhos dos policiais responsáveis pela apreensão em flagrante dos representados, bem como o laudo de constatação prévia, constituem indícios suficientes da existência material do ato infracional narrado na peça de representação, bem como de serem os adolescentes coautores da conduta.

(...) João IX possui passagens anteriores pela suposta prática de atos infracionais equiparados aos crimes de roubo majorado e furto, sendo certo que esta em cumprimento de medida socioeducativa de liberdade assistida e, nesta data, foi recebida outra representação em seu desfavor, pela suposta prática de novo ato infracional, desta feita análoga ao crime de furto qualificado.

Tais circunstâncias pessoais aconselham a decretação da internação provisória do representado João IX, sendo tal medida necessária para a garantia da segurança pessoal do adolescente, evitando-se que se coloque em situação de risco pela prática de novos atos infracionais. Por esses motivos, defiro em parte o requerido pelo MP e decreto a internação do representado João IX, o que faço com fundamento no Art. 184 caput, c.c Art. 108, ambos do ECA. Requisito-se com urgência, vaga em unidade adequada da Fundação CASA. Designo audiência de continuação para o dia 30 de abril. 


\section{Audiência de Continuação: 04/05/2015}

Sentença: É o relatório; Decido:

(...) João IX que já é reincidente e já habitual ao meio do crime, admitiu em juízo o tráfico de drogas - parou de estudar na $5^{\circ}$ série; Confessa que estava traficando neste dia; Começou vendendo drogas naquele dia; (...)

Evidente que, negou a habitualidade. Os policiais explicaram que o serviço reservado investigou e examinou a situação, indicando ao serviço ostensivo o flagrante. Não estão impedidos pela simples condição de policial - Art. 202 do CPP (Código de Processo Penal). Toda pessoa poderá ser testemunha. A simples condição de policial não torna a testemunha suspeita. Não se concebe a simples e gratuita alegação de que o depoimento dos policiais deve ser recebido com reservas. Como todo e qualquer testemunho, deve ser avaliado no contexto de um exame global de provas.

(...) A divergência de dois ou quatro meses para o nefasto tráfico, não altera o resultado. $\mathrm{O}$ comércio foi apurado pelo serviço reservado e vale o depoimento dos colegas de farda que realizaram a apreensão em flagrante. Ademais não há necessidade da prova do ato em si, mas as condições e circunstâncias indicando o fornecimento a terceiros. O local que serve ao tráfico. Os antecedentes e a reincidência de João IX. A primariedade técnica de João IX não desautoriza a conclusão. No âmbito da Fundação CASA admitiu que estava traficando para aquisição de vida e bens materiais - a frequência de balada e roupas de marca.Como adiantaram as partes, o simples concurso de agentes prevaleceu sobre a ausência de estabilidade de associação criminosa.

Passo a aplicar a medida socioeducativa.

Nãose pode adotar um critério gradual e aritmético para alcançar uma ressocialização institucional. Seria irresponsavelmente autorizar a prática reiterada de infrações, com condenações, para a proteção efetiva do vulnerável.

A medida prejudica o menor. 
O fim primordial da medida socioeducativa é protetiva e não punitiva, através da reeducação do adolescente em risco, vivenciando o meio infracional, de forma a alcançar resultados benéficos, através dos princípios da intervenção precoce, brevidade e proporcionalidade, da atualidade e da proteção integral - Art. 100 da Lei 8. 069/90. A imposição da medida socioeducativa de internação é o único meio, pela frouxidão e inexistência de legislação mais eficaz, em consonância com a realidade vigente, para que o adolescente possa compreender a gravidade dos atos praticados e receber os encaminhamentos necessários a uma efetiva socialização.

Não se confunde com o direito penal ou punitivo, não se cogitando de pena ou a forma de sua execução. O objetivo não é a punição do infrator, mas reeduca-lo ou ressocializá-lo.

Concluindo, a medida de internação a João IX não representa punição, mas essencial mecanismo de proteção ao jovem e à Sociedade.

Em parte, o mesmo se diga em relação a Marcos IX; A primariedade é apenas técnica, já que inserido no meio do tráfico há meses e carece de suporte estatal para sua proteção. O regime semiaberto é indicado. (...)

Quanto ao adolescente João IX, dando o como incurso no Art. 33 da Lei 11.343/2006, e com fundamento no Art. 122 do ECA, aplico-lhe a medida socioeducativa de internação por prazo indeterminado.

Em decorrência dos fatos aqui apurados ficam os pais ou responsáveis pelos infratores sujeitos às medidas de advertência, encaminhamento a programas oficiais ou comunitários de proteção à família e a cursos ou programas de orientação (Art. 192 ECA e Art. 52 da Lei 12.594 de 2012.

Em obediência a princípio constitucional da proteção integral e diante da necessidade de pronto encaminhamento socioeducativo não permito que o adolescente venha requerer em liberdade, devendo ser imediatamente inserido na medida aplicada. 


\section{Relatório Polidimensional Fundação CASA}

\section{Atendimento Inicial}

(...) Quanto ao ato infracional, afirma te-lo cometido juntamente com Marcos IX com intenção de usar o dinheiro para ajudar o seu genitor que está construindo (sic)

\section{Relatório Polidimensional Diagnóstico Fundação CASA}

(...) Durante entrevista junto ao adolescente João IX e pesquisa a nossos registros constatamos não possuir passagem anterior, afirmando ser seu primeiro ato infracional, contudo, menciona possuir alguns "amigos" ligados ao meio delitivo, assumindo seu envolvimento no ato pelo qual esta respondendo "Tráfico de drogas”, declarando que, como conhecia algumas pessoas ligadas ao tráfico resolveu procura-las para “trabalhar”, pois tinha umas dívidas de roupas que havia adquirido de um "colega”, além de querer adquirir mais outras, estando necessitado de dinheiro, esclarecendo que se envolveu com ato deletério pela ilusão de ganho fácil.

Salientamos que, vimos observando não apresentar maior envolvimento ou perfil delitivo, sendo educado, respeitador, calmo e tranquilo, aparentando haver sido educado dentro de padrões éticos e morais. (...)

Refere que estava traficando há um dia apenas. 


\section{$7^{0}$ Coleta de dados 08/08/2016}

Data de Nascimento: 27/12/1997

Nome Fictício: João X

Data do fato: 02/05/2015

Data do processo: 11/06/2015

Ato infracional: Tráfico de drogas e condutas afins

\section{Representação}

Consta do incluso expediente que, no dia 02 de maio de 2015, por volta das 10:45 na Rua Y, altura do Numero , nesta cidade e comarca, os adolescentes João X e Jacó X, agindo em concurso e unidade de propósitos com o maior Abraão X, traziam consigo e mantinham em depósito, para entrega de qualquer forma, a consumo de terceiros, 13 invólucros plásticos contendo crack, assim como um tijolo médio e 05 porções de cocaína, segundo laudo de constatação, substâncias entorpecentes e causadoras de dependência física e psíquica, agindo assim sem autorização e em desacordo com determinação legal ou regulamentar, além da quantia de $\mathrm{R} \$ 264,00$ em dinheiro, fruto do tráfico ilícito de drogas.

Segundo se apurou, policiais militares em patrulhamento pelo local dos fatos, avistaram três indivíduos em atitude suspeita, posteriormente identificados como os adolescentes acima citados e o imputável Abraão X. Realizada a abordagem, os milicianos encontraram com (o) o maior a quantia de $\mathrm{R} \$ 234,00$ e duas trouxinhas de maconha. Com o adolescente Jacó X foram encontradas duas porções de maconha. Finalmente com João $X$ foi encontrada uma trouxinha de maconha e 13 invólucros de crack, bem como a quantia de $\mathrm{R} \$ 30$ reais. Indagado, Abraão X 
apontou o lugar onde haviam 97 (pinos) de cocaína e um tijolo médio de maconha. Na ocasião, os três detidos admitiram a traficância, sendo conduzidos ao DP.

Trata-se desta feita, em tese, da prática de ato infracional previsto no artigo 33, “caput” da Lei 11.343 de 2006.

Ouvidos nos termos do artigo 179 do Estatuto da Criança e do Adolescente-ECA, o adolescente João X confessou o ato infracional praticado, sendo que Jacó X negou ter praticado qualquer ato infracional, na presença dos responsáveis.

Assim, com fundamento nos artigos 180, inciso III e, artigo 201 inciso II, ambos da Lei 8069/90 Represento a V. Excelência os adolescentes supramencionados, pretendendo a aplicação da medida socioeducativa prevista no artigo 112 do ECA, e requeiro a instauração do devido procedimento legal, previsto no artigo 184 e seguintes, também do mesmo Estatuto.

Destarte, é preciso requerer a decretação da internação provisória dos adolescentes. Tratase de fato grave, praticado em circunstâncias que denotam a impossibilidade, por ora, dos menores permanecerem no convívio social.

Requeiro que seja oficiado à DELPOL de origem a remessa do exame químico toxicológico das drogas apreendidas.

Frisa-se que os adolescentes são reincidentes na prática de atos infracionais, já contando com passagens por roubos. 


\section{Decisão 04/05/2015}

Juiz de Direito:

Recebo a representação ofertada pelo MP contra os adolescentes Jacó X e João X.

Para fins do exposto no Artigo 184 da Lei 8069/90, designo o dia 19/05/2015 para realização de audiência de apresentação, requisitando-se.

Os adolescentes estão respondendo a representação pela prática de ato infracional equiparado ao tráfico de entorpecente. Há indícios de autoria e materialidade, salientando-se que os jovens já possuem passagens anteriores pela Justiça menorista.

Decreto a internação provisória dos jovens, tendo em vista a manifestação do MP e que o tráfico coloca em risco a Ordem Pública, estando autorizada a internação provisória, nos termos do Artigo 174 do ECA. Há necessidade de internação para regular instrução processual. Faço consignar que o presente delito (ato infracional) é o grande mal da sociedade contemporânea, atingindo de forma difusa um número inimaginável de pessoas e famílias, além de estar associado, na maioria dos casos, à criminalidade organizada.

Equiparado aos delitos hediondos por Lei Federal editada pelo legislador e posterior ao ECA, é insuscetível por via de consequência, de concessão de fiança e liberdade provisória, em que pese à ausência de violência e grave ameaça em seu cometimento. Atualmente, a nova Lei de tóxicos (Lei Federal 11.343 de 2006), em seu artigo 44, veda tais institutos supramencionados, lei esta também posterior ao ECA.

Não obstante os institutos do Direito Penal e Processo Penal não guardarem relação matemática e linear com aqueles da Justiça menorista, forçoso o reconhecimento da vontade do legislador e da sociedade que representa ao editar tal Lei de Crimes Hediondos, no sentido de um endurecimento maior no combate a este tipo de delito, sendo que seu desprezo pelo julgador, seja 
sob qual pretexto for, atenta não só contra a lei em si, mas principalmente contra o Estado Democrático de Direito que jurou defender.

A custódia provisória autorizada pelo Artigo 188 do ECA outrossim, constitui medida cautelar que não se vincula necessariamente às hipóteses do artigo 122 do mesmo Estatuto, dependendo apenas da constatação de sua necessidade imperiosa, como ocorre na espécie, em que se busca resguardar também além da Ordem Pública, a própria segurança do infrator, o qual deve ser imediatamente afastado dos apelos criminógenos do meio.

Cumpra a Fundação CASA, as exigências do Artigo 94 e parágrafo único do artigo 123 do ECA, devendo ser remetido a este juízo até a data da audiência de apresentação, relatórios da Equipe técnica.

\section{(...)}

Nomeio um dos defensores públicos que atuam nesta Vara para atuar na defesa dos jovens, ressalvados o direito dos mesmos de, a todo tempo, constituir outro de sua preferência, nos termos do Artigo 207.

( Atos infracionais anteriores de João $X$ que constam em seu processo- pasta técnica: Roubo e posse de drogas, pelo qual cumpriu liberdade assistida anteriormente) 


\section{Audiência de Apresentação 19/05/2015}

Em 19 de maio, na sala de audiências da $3^{\circ}$ Vara Especial da Infância e Juventude, onde se achavam presentes o MM. Juiz e a Promotora de Justiça. Ao adolescente foi nomeada defensora e curadora.

Depois de cientificado de seu direito constitucional de permanecer calado, caso queira, o adolescente às perguntas respondeu: São verdadeiros os fatos narrados na representação. Nada foi perguntado pelas partes. Nada mais. Pelo MP e pela defesa foi dito que desistiam expressamente da colheita de outras provas, o que foi homologado.

Em seguida, as partes em comum acordo requereram a aplicação de medida socioeducativa de semiliberdade.

Pelo juiz foi proferido a seguinte sentença.

É o relatório. Decido. O adolescente confessou a prática do ato infracional. Não possuí ele respaldo familiar adequado para desenvolver seus freios inibitórios. Deflui-se dos elementos contidos nos autos que tal medida é suficiente para o processo de ressocialização do jovem, servindo a contenção para que ele tenha acompanhamento dos técnicos da Entidade de abrigamento, bem como a momentos de liberdade para que se reintegre à Sociedade. Não se pode olvidar, outrossim, que receberá também cursos profissionalizantes, além da continuidade da instrução básica obrigatória.

Por tais razões, a medida de semiliberdade é a que melhor se adéqua a espécie, afastandose eventuais outras medidas em meio puramente aberto e que não serviriam aos propósitos supra mencionados.

Em face do exposto julgo procedente a representação para aplicar ao adolescente João X a medida de Semiliberdade por tempo indeterminado.

(...) 
Indagado o adolescente, este manifestou o desejo de não recorrer da presente sentença.

\section{Relatório Diagnóstico Polidimensional}

\section{Inicial- Semiliberdade}

João X em atendimento inicial menciona que completará 18 anos em dezembro de 2015, de estar na $8^{a}$ série do Ensino Fundamental. Levado a refletir da importância de sua formação pessoal através dos estudos, comprometeu-se a engajar-se em suas metas estabelecidas no PIA.

Quanto a profissionalização, têm interesse maior em se colocar no mercado de trabalho a fim de custear seus gastos pessoais.

Quanto ao contexto familiar, a Sr. ${ }^{a}$ Maria X menciona que João X reside consigo desde a tenra idade, uma vez que sua mãe o teve muito nova e não tinha maturidade suficiente para cuidar do filho. Sr. ${ }^{a}$ Maria X é "avódrasta” de João X e têm muito carinho por ele, possuem bom relacionamento familiar.

Quanto à saúde, não afere afecções físicas e mentais. Admite fazer uso esporádico de maconha, lhe foi apresentado o trabalho desenvolvido pela equipe de saúde do CAPS, mas nega ser dependente químico. Entretanto o orientamos quanto aos malefícios do uso de tais substâncias no tocante aos aspectos de saúde, bem como com relação ao fator da ilegalidade. 


\section{$8^{\circ}$ Coleta de dados 21/11/2016}

Data de Nascimento: 04/01/1999

Nome Fictício: João XI

Data do fato: 23/04/2015

Data do processo: 03/06/2015

Ato infracional: Tráfico de drogas e condutas afins

\section{Representação}

Consta dos autos que, no dia 23/04/2015, por volta das 15:00 hs, na Rua W, nesta cidade e comarca, o adolescente João XI guardava e trazia consigo drogas, sem autorização ou em desacordo com determinação legal ou regulamentar.

Apurou-se que policiais civis, em diligência pelo local dos fatos, avistaram o adolescente João XI praticando atos típicos do tráfico de drogas. Abordado pelos policiais, em busca geral foram localizados, no interior de uma pochete portada pelo adolescente, 21 porções de cocaína e 07 porções de maconha (7,7 e 9,5 gramas respectivamente). Além das drogas foi encontrado em poder do adolescente a importância de $\mathrm{R} \$ 7$ reais em dinheiro, valor oriundo da prática do tráfico.

Indagado pelos policiais, João XI confessou a prática do tráfico de drogas.

As circunstâncias da apreensão, a quantidade, a forma de acondicionamento, além da confissão do adolescente, evidenciam a prática do tráfico.

Trata-se, em tese, da prática de ato infracional prevista no Art. 33, "caput” da Lei Federal 11.343/2006. Devidamente cientificado da imputação que the é feita e que ora consta da representação, o adolescente foi ouvido informalmente, nos termos do Art. 179 do ECA (Lei 
Federal 8069/90). Admitiu a prática do ato infracional e declarou que o dinheiro apreendido era proveniente do tráfico.

Assim, com fundamento nos artigos 180, inciso III e, artigo 201 inciso II, ambos da Lei 8069/90; Represento a V. Excelência os adolescentes supramencionados, pretendendo a aplicação da medida socioeducativa prevista no artigo 112 do ECA, e requeiro a instauração do devido procedimento legal, previsto no artigo 184 e seguintes, também do mesmo Estatuto.

Destarte, é preciso requerer a decretação da internação provisória dos adolescentes. Tratase de fato grave, praticado em circunstâncias que denotam a impossibilidade, por ora, dos menores permanecerem no convívio social. Ademais, João XI conta com passagens anteriores pela prática de atos infracionais e está em cumprimento de medida de Liberdade Assistida.

Requeiro que seja oficiado à DELPOL de origem a remessa do exame químico toxicológico das drogas apreendidas. Requeiro que seja decretada a perda da importância em dinheiro para o FUNAD.

Rol de Testemunhas:

1. Policial Civil 1

2. Policial Civil 2 


\section{Audiência de Continuação}

Aos 24 de abril de 2015, torno estes autos conclusos ao Dr. B, Juiz de Direito, Eu A.C, Escrivão, digitei e procedi a impressão.

Vistos.

1. Estando presentes indícios de autoria e materialidade, recebo a representação.

2. Decreto a internação provisória do adolescente João XI, residente à R: X, nos termos do Art. 108, Parágrafo único, c.c Art. 122, inciso II, ambos do ECA.

3. Ressalto que a medida é imperiosa, para garantia da segurança social do (o) (a) adolescente, bem como para manutenção da ordem pública e considerando ainda, a repercussão social do ato infracional.

4. Com efeito, tratam-se de adolescente(s) multirreincidente, que já recebeu medida de Liberdade Assistida e Prestação de Serviços à Comunidade.

5. Designo audiência de apresentação para 06/05/2015.

6. Notifiquem-se e intimem.

7. Atenda-se, no mais, o requerido pelo M.P.

8. Nomeio um Defensor Público atuante nesta Vara para defender os interesses do jovem. 


\section{Relatório Diagnóstico polidimensional Fundação CASA \\ (PIA - Plano Individual de Atendimento)}

\section{(Área psicológica)}

Elaborado o Plano Individual de Atendimento PIA, considerando informações colhidas nos atendimentos psicossociais realizados junto ao adolescente.

(..)

Nos atendimentos portou-se educadamente, manteve boa comunicação, apresenta raciocínio lógico e coerente, humor estável, orientação no tempo e no espaço, evidenciando normalidade na esfera intelectual. Em seu vocabulário, não utilizou termos próprios do meio infracional, mas denotou que vinha se vinculando com más companhias.

O adolescente não estava estudando, referiu que não tem dificuldade para aprender, repetiu um ano porque priorizou o trabalho como ajudante de pedreiro, evidenciou falta de perspectivas pelos estudos, necessitando de estímulos nesta questão.

Em relação ao ato infracional, denotou que vêm gradativamente se envolvendo no meio infracional, demonstrou vulnerabilidade ao se expor a situações de risco sem pensar nas consequências de suas atitudes; pareceu acreditar na impunidade por ser menor de idade.

(...) Sobre a família, considera o relacionamento familiar como satisfatório, porém evidenciou que não seguia as orientações e precisa de limites claros e afetivos. (...) 


\section{(Relatório da área: Serviço Social)}

Para construção deste PIA realizamos atendimentos individuais com o adolescente, entrevistas com a genitora e contato com Conselho Tutelar da Zona Sul. A partir destas informações traçamos metas de acordo com o perfil de João XI, bem como levamos em consideração aspectos relevantes de seu desenvolvimento.

Trata-se de adolescente com 16 anos de idade, o qual conta com sua segunda passagem nesta Fundação, onde atualmente cumpre medida de internação em virtude de envolvimento infracional versado em tráfico de entorpecentes.

Questionado sobre o motivo da ação ilícita, refere ter ingressado no tráfico de entorpecentes para suprir suas necessidades materiais (...)

Em relação às atividades remuneradas, João XI verbaliza não possuir experiência, mas que desenvolveu algumas atividades por um breve período, sendo em comércio alimentício como empacotador e como ajudante de pedreiro.

Sobre o uso de substâncias entorpecentes João XI menciona o uso de cigarros de maconha desde os 15 anos. Judas informa bom relacionamento com o padrasto (...)

Ressaltamos que, inicialmente o adolescente não recebia visitas de sua genitora e, ao ser indagado sobre os motivos da ausência dela, João XI nos informou que ela já havia o alertado sobre sua conduta e que não o apoiaria caso ele viesse para esta Fundação.

Por este motivo acionamos o Conselho Tutelar da Zona Sul e fomos informados que o adolescente é proveniente de lar disfuncional, sendo que ele e irmãos possuem vidas desregradas. A Conselheira nos comunicou que, a mãe se encontra fragilizada com a situação dos filhos e que ela não tem domínio sobre eles. Também que João XI por vezes se mostra agressivo e que a referida Instituição já realizou todas as tentativas de intervenções, que foram esgotadas todas as possibilidades, sem êxito. 
Durante a Entrevista, Dona Madalena XI, 40 anos de idade, declara ter estudado até a $6^{\circ}$ série do Ensino Fundamental e que há um ano e dois meses trabalha como auxiliar de limpeza em escritório. Possuí vínculo empregatício e recebe remuneração mensal de $\mathrm{R} \$ 1007,00$ mais benefícios. A mãe relata possuir 8 filhos, sendo que 3 deles são casados e possuem vidas independentes. Em sua companhia residem apenas os mais novos, são eles: J de 14 anos, estudante; U de 13 anos; V de 8 anos e o próprio João XI; A mãe informa que o filho E, de 18 anos, no momento cumpre pena em regime fechado. Também (verbaliza) que o filho $\mathrm{U}$, de 13 anos, também esta enveredando para o meio ilícito.

Dona Madalena XI menciona que há mais de 8 anos convive maritalmente com José XI, 38 anos, pedreiro, sendo ele pai apenas do filho caçula J, mas que sempre auxiliou na criação dos demais filhos.

Dona Madalena XI refere que por mais de 17 anos a família residiu em imóvel que antigamente era uma indústria de borracha e lá conviviam mais de 100 famílias, porém, com a reintegração de posse dos herdeiros, a família teve que se mudar do local e atualmente residem em área livre, tratando-se também de imóvel invadido.

Segundo nos conta a genitora, a família contava com auxílio do Programa de Transferência de Renda Bolsa Família, mas que foi desvinculada do programa em razão dos filhos desistirem da escola.

Sobre João XI, a mãe conta que com o genitor dele, não conviveram juntos (sic), sendo o adolescente o único filho daquele relacionamento e que ele contribuiu com as despesas do filho apenas nos primeiros anos de vida e posteriormente se eximiu de qualquer responsabilidade.

A mãe relata que, desde pequeno João XI ficou sob os cuidados da progenitora materna, Senhora Ester XI de 63 anos de idade e portadora de doença de Chagas. Acrescenta que a mãe era muito sozinha e por isso João XI ficou sob os cuidados dela.

Verbaliza que apesar de tudo, ela sempre foi muito presente na vida do filho e que acompanhava sua vida escolar. 
Sobre o uso de drogas, a mãe afirma que o filho usa maconha desde os 10 de idade. Ainda que, inicialmente, a família não tinha conhecimento (do uso), mas descobriu este vício quando João XI voltou ao convívio materno, sendo que na ocasião, contava com 13 anos de idade.

A mãe coloca ainda que, diante das atitudes do filho, procurou auxílio junto ao Conselho Tutelar e ao CREAS, mas que não logrou êxito em seu intento. A mãe relata que o apoio de outras figuras parentais, tios maternos, que já tentaram ajuda-lo na inserção ao mercado de trabalho, mas João XI não aceitava.

(..) 


\section{$9^{\circ}$ Coleta de dados 12/12/2016}

Data de Nascimento: 01/08/1999

Nome Fictício: João XII

Data do fato: 22/06/2015

Data do processo: 31/08/2015

Ato infracional: Tráfico de drogas e condutas afins

\section{Representação}

O Ministério Público de São Paulo, por intermédio do Promotor de Justiça que subscreve a presente, vêm respeitosamente oferecer representação e pedir a instauração de procedimento para apuração de ato infracional e aplicação de medida socioeducativa em face do adolescente João XII, já qualificado nos autos em epígrafe, tendo em vista o que segue.

Consta dos autos que, no dia 11/05/2015, por volta das 20 horas, na Rua $\mathrm{H}$, neste município e comarca, o representado trouxe consigo, guardou e expôs à venda, sem autorização e em desacordo com legislação complementar, com a finalidade de entrega a terceiros (tráfico), substâncias entorpecentes que causam dependência física e psíquica, a saber: 18 (dezoito) pedras de ‘crack”, um derivado da cocaína; e 21 (vintee uma) porções de maconha (Cannabis Sativa).

Apurou-se que, nas referidas circunstâncias de tempo e lugar, o representado se encontrava em via pública exercendo o tráfico de drogas. Ele portava dezenas de porções de crack e maconha, além de alguns frascos da substância conhecida como "lança perfume” e também a quantia de $\mathrm{R} \$ 32,00$ em dinheiro, proveniente da espúria atividade em questão.

A conduta praticada pelo apresentado se assemelha àquela tipificada no artigo 33, “caput”, da Lei 11.343/2006. 
Ouvido informalmente na presença de sua genitora, o adolescente CONFESSOU a prática do ato infracional. Posto isto, Represento á Vossa Excelência o adolescente Judas IX e requeiro que, recebida e autuada esta, prossiga-se nos termos do rito processual previsto no art. 184 e seguintes do Estatuto da Criança e do Adolescente, citando-se e intimando-se o representado e seus responsáveis legais para audiência de apresentação, ouvindo-se oportunamente, as pessoas abaixo arroladas, prosseguindo-se até final aplicação ao representado da medida socioducativa que se afigurar a mais adequada, dentre as previstas no artigo 112 do referido Estatuto.

Mostra-se imperiosa a decretação da internação provisória do adolescente, pois demonstrou não possuir estrutura pessoal e familiar alguma para permanecer em liberdade, uma vez que praticou ato infracional gravíssimo, correspondente a delito equiparado aos hediondos, cuja repercussão social recomenda sua custódia cautelar para garantia de sua segurança pessoal e manutenção da ordem pública (Art. 174, parte final do ECA). Demais, o jovem não conta com respaldo familiar. Nenhum parente se fez presente na Delegacia de Polícia ou neste Fórum para acompanhar João XII. 


\section{Audiência de Apresentação}

Aos 12 de maio de 2015, nesta cidade de São Paulo, no horário designado, na Sala de audiências da Segunda Vara Especial da Infância e Juventude, comigo escrevente, ao final assinado. Iniciados os trabalhos, presente o MM. Juiz, o Representante do MP e a Defensora Pública. Pelo juiz foi dito que: Recebo a representação de folhas 02 e 03, ofertada pelo MP contra o adolescente, tendo em vista as indicações de autoria e materialidade constante dos autos e o designo da audiência de apresentação para a data de hoje. Compareceu o adolescente João XII. Presente os responsáveis. As perguntas formuladas ao adolescente foram registradas em mídia audiovisual, que foi anexada aos autos. A seguir, pela defesa foi dito que: MM. Juiz, o adolescente foi representado e esta sendo processado pela suposta prática de ato infracional, correspondente ao crime de tráfico de drogas. É primário, estuda e esta inserido em núcleo familiar,contando com respaldo familiar. Reside em endereço fixo.em primeiro lugar, ainda que procedente a representação, o caso não se enquadra em nenhuma das hipóteses legais para a imposição da medida de internação, nos termos do Art. 122 do ECA: o adolescente é primário e o ato não foi cometido mediante violência ou grave ameaça. Desse modo, a custódia cautelar mostra-se desproporcional e será violadora do princípio da homogeneidade (a medida cautelar é mais gravosa que o resultado final possível para a demanda). Não bastasse isso, no aspecto da excepcionalidade, o Supremo Tribunal Federal (STF) já firmou, na súmula 492, o entendimento de que o ato análogo a tráfico de drogas não conduz obrigatoriamente à medida extrema e, no presente caso, as condições pessoais do adolescente indicam a possibilidade de intervenção em meio aberto. Diante do exposto, não está evidenciada a necessidade imperiosa da internação provisória, nos termos do Ar. 108 do ECA, razão pelo qual requeiro que o adolescente possa aguardar o julgamento do feito em liberdade. Nada mais. A seguir, pelas partes foi dito que requerem designação de audiência de instrução. A seguir em defesa prévia assim foi dito: a defesa protesta pela improcedência da representação como restará provado ao final da instrução processual. Arrolam-se como testemunhas as mesmas arroladas pelo MP, protestando-se desde já por sua eventual substituição, caso seja necessário. Pelo MM. Juiz foi dito: Vistos. Trata-se de pedido de internação provisória de adolescente com postulação adversa da defesa. 
É o relatório. Decido. Os fatos aqui indicados são veementes e apontam que o adolescente estaria atravessando situação de importante exposição social. Diante disso a internação provisória é no momento necessária para preservação de sua integridade. Em face do exposto decreto a internação provisória do adolescente. No mais designo audiência de continuação para 18/06.

\section{Relatório Diagnóstico Polidimensional Fundação CASA}

\section{área psicológica}

O presente parecer psicológico foi elaborado através de entrevista com o adolescente e a responsável, discussão do caso entre a equipe, consulta às pastas e observação de comportamento neste Centro.

O adolescente João XII (quinze anos), até presente momento, apresenta bom relacionamento interpessoal, demonstrando adaptabilidade. Apresenta linguagem adequada não utilizando uso de gírias ou termos do meio infracional.

Com relação ao desenvolvimento cognitivo, denota pensamento lógico, apresentando memória, atenção e compreensão preservadas e adequadas à sua faixa etária. Refere que reside com os genitores, Sr. José XII e Sra. Madalena XII, além de seus irmãos. Descreve o relacionamento familiar como satisfatório, é orientado com relação ao consumo de drogas, aos estudos e amizades. Quanto a atividade estudantil, refere que preferiu trabalhar de ajudante de pedreiro com o genitor, com a finalidade de ajudar a família financeiramente. Menciona pretensão em continuar os estudos e realizar curso de qualificação para o trabalho.

Quanto ao uso de substância psicoativa, nega experimento ou consumo de substâncias psicoativas. Admite o consumo de tabaco. Acresce que os genitores também fazem uso de tabaco. 
O adolescente foi orientado com relação aos prejuízos causados pelo consumo excessivo destas substâncias. Com relação à prática infracional, o adolescente assume a participação e justifica que ficou iludido com os altos valores e tinha intenção de obter roupas. Refere arrependimento de sua conduta.

Para um melhor entendimento do caso, realizado contato com a Sra. Madalena XII, que descreve João XII como um bom filho, educado e trabalhador, mas apesar de orientado a continuar os estudos, preferiu trabalhar com o Sr. José XII. Acresce que a família passou por dificuldades financeiras com o desemprego do Sr. José XII, que posteriormente iniciou laboro de pedreiro e percebeu que João XII ficou muito preocupado e decidiu ajudar o pai na atividade de ajudante de pedreiro. Relata acreditar que João XII foi influenciado pelas amizades equivocadas, pois não tem necessidade de participar do meio ilícito. Menciona que tem realizado as visitas ao filho e realizado orientações.

O contexto familiar denota vínculos afetivos preservados, necessitando de imposição de limites e acompanhamento mais efetivo com relação ao adolescente. Durante os acompanhamentos, o adolescente denota bom controle dos mecanismos contensores e não demonstrou mudança de humor. Denota sentimentos de baixa auto estima e vêm recebendo orientações quanto a importância de refletir sobre suas ações, assim como, a importância em dar continuidade a atividade estudantil, com inclusão de cursos para qualificação profissional. Importante que o adolescente participe de programa de orientação psicossocial. 


\section{Relatório Diagnóstico Polidimensional Fundação CASA}

\section{área social}

Este documento foi confeccionado através de atendimento ao adolescente, leitura de prontuários e discussão do caso junto à equipe de referência.

João XII possuí 15 anos e adentrou nesta CASA Rio Paraná em 13/05/2015, devido a envolvimento infracional equiparado ao tráfico, ocasião em que recebeu orientações acerca de normas e regras institucionais, conduta comportamental e assuntos pertinentes a sua situação processual. Participa de atividades esportivas, pedagógicas e culturais, com boa adaptabilidade e participação junto aos demais.

Quanto ao seu contexto sociofamiliar, declara residir com seus genitores e seis irmãos, a saber: $\mathrm{W}$ de 14 anos, R de 17 anos, G de 9 anos, L de 6 anos, M de 8 anos e A de 21 anos. Residem na Comunidade Jardim X, em ocupação irregular e próxima à região do pico do Jaraguá, em moradia edificada em madeira e composta por três cômodos. Refere que a moradia foi construída sobre um córrego e conta com infraestrutura adequada. O sustento mensal é adquirido através da atividade trabalhista de sua genitora, na função de auxiliar de limpeza, com proventos em torno de $\mathrm{R} \$ 980$ e de seu genitor na função de pedreiro com rendimentos de $\mathrm{R} \$ 1500$ por mês.

Quanto a relação pai versus filho, menciona que o relacionamento é positivo e pautado em respeito e imposição de limites, todavia, através do contato realizado com ambos, observamos que sua mãe não conseguiu se firmar enquanto um referencial adequado de autoridade. Os vínculos estão preservados.

No ano de 2014 abandonou os estudos, não desenvolveu atividade básica e labora como servente de pedreiro. Ao falar de sua atividade trabalhista, o faz de forma positiva e fala do seu desejo de conseguir inserção formal no mercado de trabalho. Neste Centro participa quinzenalmente do grupo Narcóticos Anônimos, organização de apoio aos dependentes do uso de drogas, que tem como objetivo, compartilhar experiência coletiva de como abandonar o vício. 
Junto a esta equipe, tem recebido orientações sobre os danos desta conduta para o seu desenvolvimento social.

A genitora durante, intervenção, refere sua preocupação com o processo educacional do jovem e com objetivo de afastá-lo de amizades e aderências negativas, buscará inseri-lo em atividades extra curriculares.

Durante os atendimentos, o jovem demonstrou atenção para com os nossos aconselhamentos e, até onde nos foi possível apurar, apresenta criticidade em construção, mas responde de forma positiva as nossas intervenções. Observa-se a necessidade da continuidade da contextualização, das orientações sobre as consequências sociais de suas escolhas e também possibilidades advindas do exercício de sua cidadania, sendo a rede de serviços um importante instrumento para amparar a sí e familiares na reflexão efetiva da importância de sua cidadania.

\section{Relatório Serviço de Medida socioeducativa em meio aberto (PIA- Plano individual de atendimento)}

A genitora refere que é casada com o companheiro há cerca de 21 anos, oriundos do estado de Pernambuco, vieram para São Paulo em busca de melhores condições de trabalho (...)

Em discussão com a equipe pode-se constatar que o ato infracional esteve diretamente relacionado à questão econômica, além de considerar que João XII parece que não tinha discernimento da gravidade desta prática (...) 
